\title{
Dynamics of Land-Use Change and Conservation in the Prairie Pothole Region of the United States-Environmental and Economic Implications with Linkages to Rural Community Well-Being
}
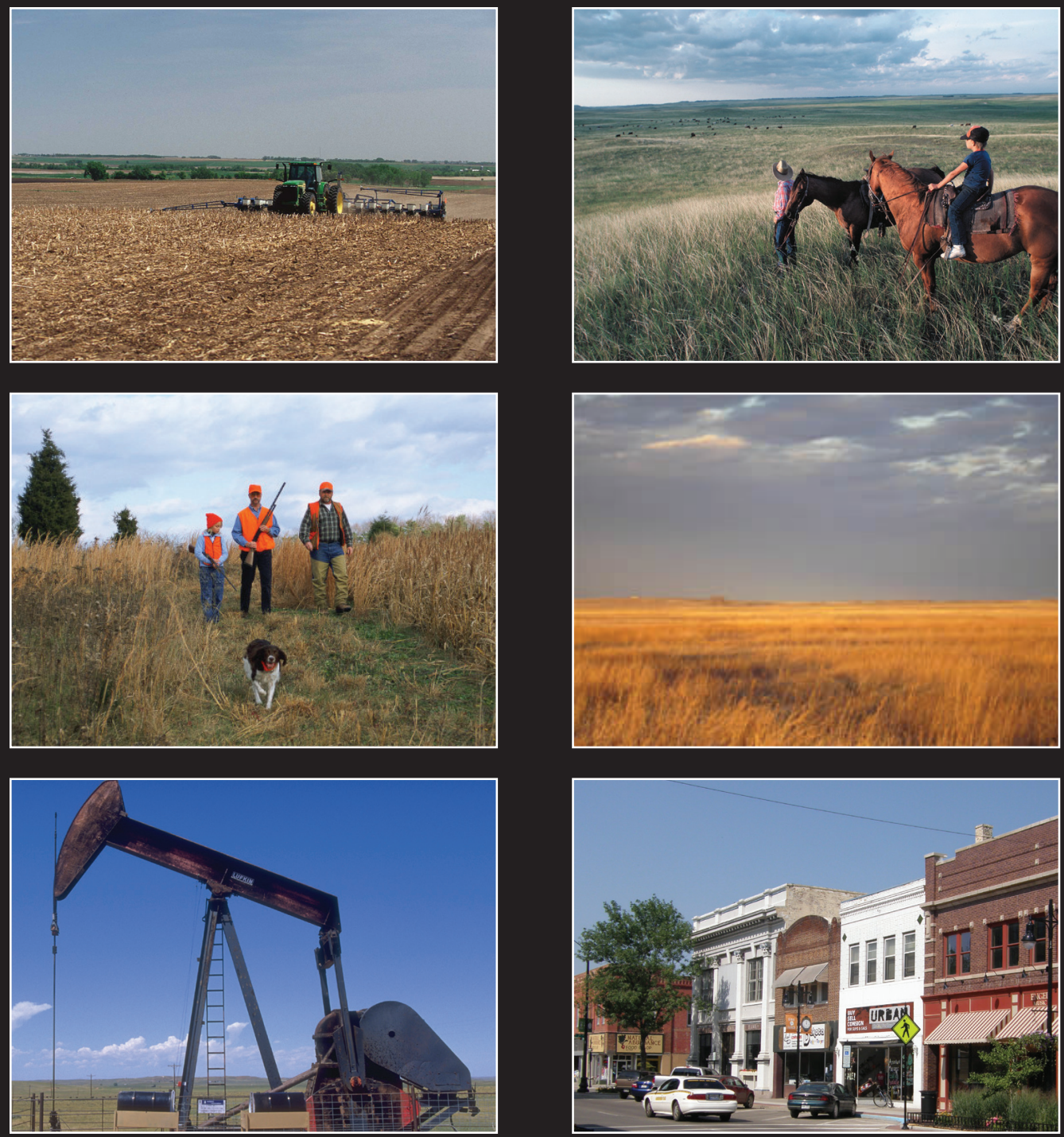

Professional Paper 1800 


\section{Front cover}

Left: Photograph by Don Poggensee, U.S. Department of Agriculture Natural Resources Conservation Service Photograph by Brett Billings, U.S. Department of the Interior Fish and Wildlife Service

Photograph obtained from the Wyoming Office, U.S. Department of the Interior Bureau of Land Management

Right: Photograph by Tim McCabe, U.S. Department of Agriculture Natural Resources Conservation Service Photograph by Tom Koemer, U.S. Department of the Interior Fish and Wildlife Service

Photograph by Justin Goetz

\section{Back cover}

Photograph by Mark Vandever, Department of Interior, U.S. Geological Survey 


\section{Dynamics of Land-Use Change and Conservation in the Prairie Pothole Region of the United States-Environmental and Economic Implications with Linkages to Rural Community Well-Being}

Edited by William Gascoigne, Dana Hoag, Rex Johnson, and Lynne Koontz

Prepared in cooperation with the Plains and Prairie Potholes Landscape

Conservation Cooperative

Professional Paper 1800 


\title{
U.S. Department of the Interior SALLY JEWELL, Secretary
}

\section{U.S. Geological Survey \\ Suzette M. Kimball, Acting Director}

\author{
U.S. Geological Survey, Reston, Virginia: 2013
}

For more information on the USGS — the Federal source for science about the Earth, its natural and living resources, natural hazards, and the environment, visit http://www.usgs.gov or call 1-888-ASK-USGS.

For an overview of USGS information products, including maps, imagery, and publications, visit http://www.usgs.gov/pubprod

To order this and other USGS information products, visit http://store.usgs.gov

Suggested citation:

Gascoigne, W.R., Hoag, D.L., Johnson, R.R., and Koontz, L.M., eds., 2013, Dynamics of land-use change and conservation in the Prairie Pothole Region of the United States-Environmental and economic implications with linkages to rural community well-being: U.S. Geological Survey Professional Paper 1800, 65 p., http://pubs.usgs.gov/pp/1800/.

Any use of trade, firm, or product names is for descriptive purposes only and does not imply endorsement by the U.S. Government.

Although this information product, for the most part, is in the public domain, it also may contain copyrighted materials as noted in the text. Permission to reproduce copyrighted items must be secured from the copyright owner. 


\section{Acknowlegments}

The study was commissioned by the Plains and Prairie Pothole Landscape Conservation Cooperative. For their assistance and cooperation, we thank personnel from U.S. Fish and Wildlife Service (Regions 3 and 6), U.S. Department of Agriculture Natural Resources Conservation Service (NRCS) and Farm Service Agency (FSA) state offices, the Minnesota Department of Natural Resources, the lowa Department of Natural Resources, the South Dakota Department of Game, Fish, and Parks, and the North Dakota Game and Fish Department.

A number of folks provided data and research insight, whom the authors thank for their efforts. These include, but are not limited to, Dean Bangsund, Larry Gigliotti, Chris Peterson, Matthew Filsinger, Matt Sprenger, Terry Allbee, Elaine Hornaday, Doug Helmers, Lori Nordstrom, Dan Hartel, Chuck Loesch, Tammy Fairbanks, Lou Cornicelli, Tara Chesley-Preston, Guy Zenner, Todd Bogenschutz, Drew Ignizio, Tammy Fancher, Margaret Dexter, Johann Walker, Rick Nordby, Monica Monk, Todd Hagel, Randy Meissner, Chris Ensminger, Myron Taylor, Timothy Loesch, Sandi Edmunds, Bill Mulvaney, Sandy Hutchcroft, Kathy Hunter, Peter Fritzell, John Corrigan, Kurt Forman, Ron Reynolds, Skip Hyberg, Bill Jenson, and a handful of county commissioners in the region. We would also like to thank Mark Vandever and Brian Tangen for their earlier review of this document. Although these individuals contributed to this report, the authors, alone, assume full responsibilities for all the interpretations of the literature, assumptions, and conclusions in this document. 



\section{Contents}

Executive Summary-Lessons Learned and the Future of Conservation

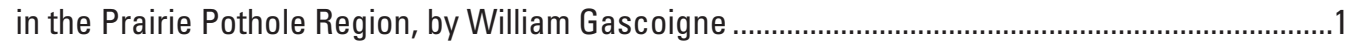

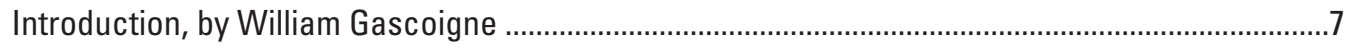

Chapter 1-Land-Use Dynamics in the Prairie Pothole Region,

by William Gascoigne ..............................................................................................................

Farming in the Prairie Pothole Region..............................................................................

Oil and Gas Boom in the Prairie Pothole Region ..............................................................13

Perennial Habitat in the Prairie Pothole Region ....................................................................16

Chapter 2-The Prairie Pothole Region Economy and Economic Linkages

to the Landscape, by William Gascoigne, Dana Hoag, Lynne Koontz, and

Catherine Cullinane Thomas .......................................................................................................

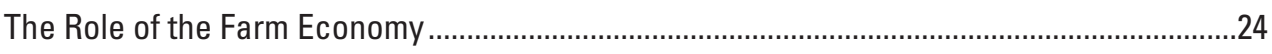

Economic Contributions of Perennial Habitat Lands ..........................................................26

Hunting and Wildlife Viewing in the Prairie Pothole Region .................................................32

National Wildlife Refuge System Operations and Partners for Fish

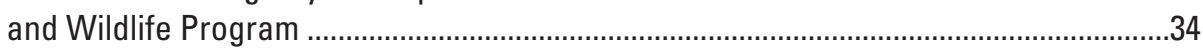

Case Study Highlight: Glacial Ridge Restoration, Polk County, Minnesota ..............................35

Chapter 3-Land Use and Rural Development, by William Gascoigne and Rex Johnson ...............37

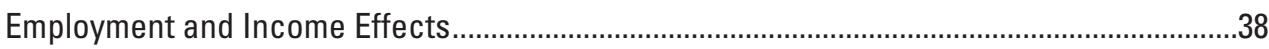

Population and Migration Patterns in the Prairie Pothole Region-

Cause and Effects ........................................................................................................

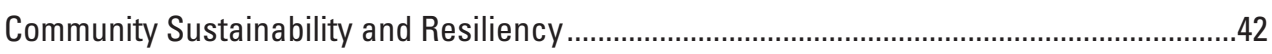

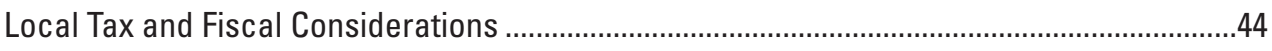

Conclusions Regarding Land Use and Rural Development ...................................................44

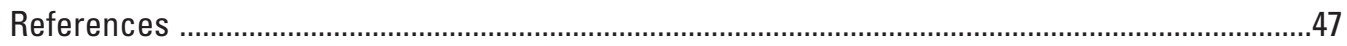

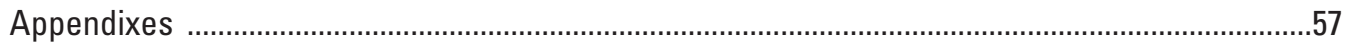

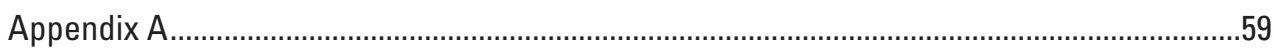

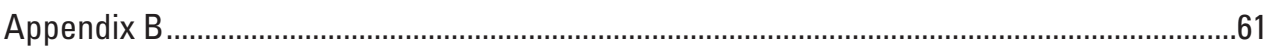

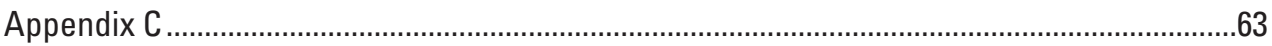

\section{Figures}

1-1. Map showing the Great Plains Region and Prairie Pothole Region of North America

1-2. Map showing percentage of land in farms by county for the United States, 2007

1-3. Map showing corn for grain production in North Dakota, 2006 and 2011 ........................14

1-4. Map showing soybean production in North Dakota, 2006 and 2011 ...............................15

1-5. Graphs showing oil production in North Dakota and within Bakken

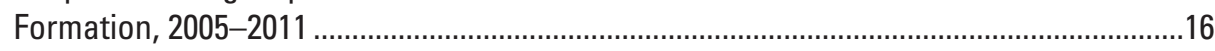

1-6. Map of the extent of Bakken Formation and Williston Basin in the Prairie Pothole Region of United States and Canada. 
1-7. Map showing perennial habitat distribution in the Prairie Pothole Region of the United States., based on U.S. Fish and Wildlife Service Habitat and Population Evaluation Team (HAPET) land-cover data.

1-8. Map showing percentage of county acres classified as perennial habitat in the Prairie Pothole Region of the United States, based on U.S. Fish and Wildlife Service Habitat and Population Evaluation Team (HAPET) landcover data

1-9. Map showing perennial habitat acreage in the Prairie Pothole Region of the United States as defined by lands with a protected (short- and long-term) status, conserved status, or managed for wild life-friendly cover displayed as a percentage of total county acres

2-1. Graph showing farm employment by year as a percentage of total employment for the Prairie Pothole Region of the United States, 1969-2010......

2-2. Graph showing lowa conservation program acres, corn/soybean acres, and pheasant-count figures, 1940-2011.

2-3. Graph showing correlation between pheasant populations and number of upland game bird hunters in lowa, 1963-2010. 31

3-1. Map showing United States counties with highest outmigration levels from 1998-2008

A-1. Map of the Prairie Pothole Region of the United States as defined for this report. .59

\section{Tables}

1-1. Farmland statistics for North Dakota, South Dakota, Minnesota, and lowa from 1959-2007

1-2. Enrolled Conservation Reserve Program (CRP) acres in North Dakota, South Dakota, Minnesota, and lowa in 2007 and 2010, and percentage change between those years

1-3. Conservation Reserve Program (CRP) contract acreage expiring within North Dakota, South Dakota, Minnesota, and lowa, 2011-2017.

2-1. Total employment in the Prairie Pothole Region of the United States by sector, 2010 .

2-2. Farm dependency of Prairie Pothole Region counties in the Unites States, 2010

2-3. Total (direct and secondary) economic contribution of hunting and wildlife viewing to the United States Prairie Pothole Region economy

2-4. Total (direct and secondary) economic contributions of U.S. Fish and Wildlife Service National Wildlife Refuge System operations and the Partners for Fish and Wildlife Program.

3-1. Estimates of city population required to support an indicated number of establishments of selected business types, North Dakota, 2000.

B-1. Definitions of land-cover classes used in the 2006 U.S. Fish and Wildlife Service Habitat and Population Evaluation Team (HAPET) land-cover database for the Prairie Pothole Region of the United States

B-2. Explanations of ownerships and land classifications in conserved- or protected-status lands of the Prairie Pothole Region, United States, including modeling notes in reference to figure 1-9 of this report

C-1. Data sources for economic contributions of hunting in the Prairie Pothole Region of the United States, arranged by state and respective faunal targets. 


\section{Abbreviations Used in this Report}

$\begin{array}{ll}\text { BEA } & \text { Bureau of Economic Analysis } \\ \text { CREP } & \text { Conservation Reserve Enhancement Program } \\ \text { CRP } & \text { Conservation Reserve Program } \\ \text { DOI } & \text { Department of the Interior } \\ \text { ERS } & \text { Economic Research Service } \\ \text { FSA } & \text { Farm Service Agency } \\ \text { GRP } & \text { Grassland Reserve Program } \\ \text { HAPET } & \text { Habitat and Population Evaluation Team } \\ \text { mbbl/d } & \text { Thousand barrels per day } \\ \text { mmbbl/d } & \text { Million barrels per day } \\ \text { NPS } & \text { National Park Service } \\ \text { NRCS } & \text { Natural Resources Conservation Service } \\ \text { NWR } & \text { National Wildlife Refuge } \\ \text { NWRS } & \text { National Wildlife Refuge System } \\ \text { PFW } & \text { Partners for Fish and Wildlife } \\ \text { PLOTS } & \text { Private Land Open To Sportsmen } \\ \text { PPR } & \text { Prairie Pothole Region } \\ \text { USDA } & \text { United States Department of Agriculture } \\ \text { USFWS } & \text { United States Fish and Wildlife Service } \\ \text { USGS } & \text { United States Geological Survey } \\ \text { WIA } & \text { Walk-In-Access } \\ \text { WRP } & \text { Wetland Reserve Program } \\ \text { WPA } & \text { Waterfowl Production Area } \\ & \end{array}$





\title{
Executive Summary-Lessons Learned and the Future of Conservation in the Prairie Pothole Region
}

\author{
By William Gascoigne
}

There were a number of goals guiding this research effort. They include (1) providing a comprehensive review (chap. 1) of land use (past and present) in the Prairie Pothole Region (PPR), (2) identifying and articulating linkages (chaps. 2 and 3) between landscape conditions and economic variables, (3) estimating the economic contribution (chap. 2) of perennial habitat lands in the region, and (4) synthesizing the quantitative and qualitative research findings regarding aspects of rural-community well-being as influenced by land-use decisions (chap. 3). The goal was not to promote one land use over another. Rather, the goal was to provide insight into the economic implications and community well-being aspects pertaining to land-use decisions. The study does focus on the economic effects of restoring perennial habitat, as these relationships are often indirect and not easily ascertained. The evolution of farm structure, farm dependency of rural communities, and economic influence of farming form another focus of the study, as farmland is the dominant land use in the region and a major component of the region's economic output.

\section{So, what have we learned?}

The data presented in chapter 1 - Land Use Dynamics in the Prairie Pothole Region - showed us land use in the prairies has evolved substantially and stands to change even more in the future. With respect to agriculture, a vast majority of the land in the PPR remains in farmland (fig. 1-1). In actuality, the amount of land in farms and devoted to cropland has remained relatively constant or minimally decreased in each of the four PPR states considered for this study (North Dakota, South Dakota, Minnesota, Iowa) when compared to 1959 levels. Farm consolidation occurred over the years, however, which has increased the average size of farms in the region. One of the largest changes in the PPR involves the respective crop mix being planted. Economic incentives and advancements in crop genetics have resulted in record-high plantings of corn and soybeans. Once planting 7-12 commodities, the average producer in North Dakota is now planting only 2-5 commodities (J.C. Hadrich, Colorado State University, custom query from North Dakota Farm Business Management Association 2010 Data Set and State Report, written commun., 2012). This change was echoed during a conversation with a southwestern Minnesota county commissioner. He quickly noted that producers in his county who historically dedicated a portion of their land to small grains were down strictly to a two-crop rotation of corn and soybeans.

As of 2007, land in cropland production across the four states totaled around 85 million acres. The expansion of new corn and soybean acres largely has occurred on the western boundary and to the north (figs. 1-3 and 1-4). Temperature and precipitation affect the crop mix across the PPR, and some future-climate scenarios support a continued expansion of corn and soybeans (Ingwersen, 2013). However, crop production in the region seems to be tied much more to farm and energy policies that have significant influence on economic drivers (DeVore, 2012; Miao and others, 2012; R. Leupold, Dickinson County [Iowa] Conservation Board, oral commun., April 2012; R. Renner, Ducks Unlimited, oral commun., April 2012). The final legislative and funding structure of the current Farm Bill (and subsequent bills) is expected to greatly impact land-use decisions in the region, including crop mix. Likewise, decisions regarding ethanol mandates and federal subsidy supports stand to impact the agricultural makeup of the PPR.

Oil and gas production in the PPR has increased exponentially in the last few years, with North Dakota recently surpassing Alaska as the state with the second-highest oil volume in the country (North Dakota Industrial Commission, 2013). Current data show there are more than 8,200 active production wells, with close to 200 new wells going in each month (North Dakota Industrial Commission, 2013). Some experts have estimated potential for another 20,000-30,000 wells likely to be drilled in the next 10-20 years (Holywell, 2011). Carrying capacity of the Bakken Formation alone is estimated to be around 39,000 wells, with indications that it will prove to be the largest oil field in U.S. history (Mason, 2012). Transportation and delivery infrastructure needs, as well as increased demand for inputs such as gravel and sand, will continue to alter the PPR landscape.

Chapter 1 also documents the spatial distribution of perennial habitat in the PPR (figs. 1-7, 1-8, and 1-9). While the region has experienced extensive conversion of native prairie to cropland, a significant distribution of land cover classified as perennial habitat remains. Working with USFWS Habitat and Population Evaluation Team (HAPET) landcover data, our maps reveal substantial variation. Counties 
displaying the highest percentages of perennial habitat in North Dakota include Burleigh, Eddy, Emmons, Kidder, Logan, McHenry, McIntosh, Rolette, and Sheridan. Those in South Dakota include Aurora, Brule, Buffalo, Campbell, Hand, Hyde, Jerauld, Marshall, McPherson, Sanborn, and Walworth. Minnesota counties with high proportions of perennial habitat include Becker, Mahnomen, Otter Tail, and Roseau. Lower concentrations of remaining habitat are displayed along the shared boundary between the Dakotas and Minnesota, with the lowest distribution observed in the southwestern part of Minnesota and into the northern counties of Iowa. All but three Iowa counties in the PPR had perennial habitat percentages below 15 percent. Combining spatial and tabular data for lands in a protected (short- and long-term) status and/or managed for wildlife-friendly cover paints a slightly different picture. County percentages are much smaller (as was expected), with a few select counties displaying much more habitat than the rest. Those include Ransom County, North Dakota; McPherson and Marshall Counties in South Dakota; Kittson, Roseau and Marshall Counties in Minnesota; and Dickinson County, Iowa.

Lands enrolled in the Conservation Reserve Program (CRP) are included in the perennial-habitat proportion maps and are a key focus of the chapter given the prominence of the program in the northern Great Plains states. After peaking in 2007, CRP acreage in the PPR has declined by over 1 million acres, or roughly 18 percent. In 2010, just over 4.8 million acres of CRP remained in the region. With very strong commodity prices at a time in which many CRP contracts are set to expire, there is strong potential that CRP acreage will continue to decline. From 2011-2013 alone, nearly 3 million CRP-contract acres will expire within the four PPR states. An additional 1.8 million acres will expire between 2014 and 2017. Survey responses from CRP contract holders indicate a majority of them are either unsure or not likely to reenroll, with a majority of respondents noting they likely would put the land back into production (Hodur and others, 2004; Janssen and others, 2008). Tightened fiscal allocations in the upcoming Farm Bill are likely to challenge the prominence of the conservation program even further.

A number of findings are presented in chapter 2-The Prairie Pothole Region Economy and Economic Linkages to the Landscape. First, the role of the farm economy in the PPR was investigated. A fair number of farming-dependent counties exist in which farm occupations constitute 15 percent or more of the county employment base; the greatest number of such counties are in South Dakota (table 2-2). Sheridan County and Kidder County in North Dakota have the two highest farm-employment percentages of any county in the PPR, at around 35 percent. However, when examined regionally, farm employment accounts only for just over 6 percent of total employment in the PPR. For context, in 1969 farm employment was over 18 percent of the entire regional workforce. Current results show that farming has a much smaller employment footprint at the regional level, while still showing prominence at smaller, local scales. Concurrently, the USDA shows the off-farm income share of total farmhousehold income rose from about 50 percent in 1960 to more than 80 percent over the last 10 years (Fernandez-Cornejo, 2007). In reference to these trends, agricultural economist Stephen Deller and others (2003) note, "the commonly held belief that a healthy farming economy translates into a strong rural economy has been turned on its head; rather, a strong rural economy is a necessary condition for robust farm-household income."

Findings regarding the economic contribution of perennial habitat lands also were presented in chapter 2 . A vast amount of research documents the wildlife habitat and ensuing population benefits of the CRP. As an example, Reynolds and others (2007) modeled the habitat benefits of the CRP to migratory waterfowl in the PPR and concluded that program acres were responsible for an additional 1.9 million ducks per year. Conversely, there is an inventory of data showing the decline in species populations as CRP acres decline. Using data provided by the Iowa Department of Natural Resources, we were able statistically to confirm a strong correlation between pheasant populations and the number of hunting licenses sold. From a peak in 1973 until 2010, the number of upland bird hunters in Iowa declined by 80 percent, equating to nearly 250,000 hunters. The pheasant population and number of pheasant hunters in 2010 were the lowest in recorded history in the state. Applying spending profiles of upland game hunters in that region to these estimates and uploading them into an economic model that tracks linkages between sectors and the resulting ripple effect of spending, the model estimated that this loss in spending activity equates to just under 4,000 jobs, \$102 million in labor income, and around $\$ 170$ million in value added to the state's economy. ${ }^{1}$

Similar economic models were run for region-wide hunting and wildlife viewing on USFWS lands in the PPR. Modeling indicated that these outdoor recreational activities contribute close to 10,000 jobs, $\$ 760$ million in labor income, and $\$ 450$ million in value added to the region's economy. Outdoor recreation continues to be a major contributor to the area's multi-billion-dollar tourism industry, an industry that continues to grow in the face of declines elsewhere in the country (Hodur and others, 2008; North Dakota Department of Commerce, 2011). Empirical research has shown recreation-associated spending resulting from habitat conservation can offset significant portions of agricultural losses depending on geography and soil productivity (Bangsund and others, 2004).

Operational management and restoration activities also are a source of revenue streaming from conserved habitat. At the forefront, the USFWS oversees a number of properties through its National Wildlife Refuge System (NWRS) and

${ }^{1}$ See chapter 2 regarding assumptions and limitations of the estimation. 
works to restore additional habitat on private land through its Partners for Fish and Wildlife (PFW) program. Detailed budget information was used to model the contribution of NWRS operations to the region's economy. Actual receipts from a sample of private land-restoration projects were used to do the same for the PFW program. Together, the programs provide nearly 900 jobs, $\$ 40$ million in labor income, and \$50 million in value added within the region. ${ }^{2}$

Continuing down the path of chapter 2, chapter 3Land Use and Rural Development — synthesizes research findings regarding aspects of community well-being and rural development as they pertain to landscape conditions. It is understood that community well-being has both quantitative and qualitative dimensions. Community well-being relates to numerical statistics such as job and income growth, along with population trends, as well as concepts such as social capital (that is, ability to come together to address challenges) and quality of life.

Focusing initially on employment and income patterns, the report analyzes the role of the farming sector. It has long been expressed that a healthy farm economy equals a healthy rural economy. This viewpoint was upheld in conversations with county commissioners. Simply put, "Our community is in a healthy state given commodity prices are so good right now." Statistics show that rural communities in the PPR, however, are growing more and more dependent on off-farm employment and income (Deller and others, 2003; FernandezCornejo, 2007). Additionally, farm consolidation across the landscape is captured in agricultural statistics and verified by local stakeholders. Farm consolidation in stride with technological advances has increased production volumes while reducing demand for hired farm labor and displacing farmers and their families. A weak off-farm economy in an area experiencing farm consolidation is likely to fall into continuous outmigration and negatively impact local employment opportunities (Kulcsár and Bolender, 2011). Literature findings suggest the decline in farm employment largely is a result of changes in farming itself; not necessarily a result of outside stressors.

In terms of employment and migration impacts, empirical and qualitative research indicates people follow jobs just as much as jobs follow people. In-migration typically leads to greater demands for local goods and services, with business and job opportunities to follow. In that light, it is extremely important for rural-development policies to be geared not only toward attracting businesses and accompanying jobs, but also to pay great attention to retaining and attracting new residents. That begs the question, "what aspects are attractive to potential residents?" Certainly included are economic aspects such as job opportunities, relative wages, and cost of living, but also included are a suite of non-economic amenities that

\footnotetext{
${ }^{2}$ This estimate does not include economic values associated with visitation on National Wildlife Refuge lands. Carver and Caudill (2007) discussed this contribution.
}

incorporate environmental conditions, view-shed aesthetics, and outdoor-recreation opportunities. Recent questionnaires filled out by those moving to and from rural towns in the Great Plains (Cantrell and others, 2008; Rural Community Assistance Corporation, 2011) indicated outdoor-recreation opportunities and a desirable natural environment were key factors in decision-making. Similar replies are heard even more from the current generation entering the workforce (Ryan, 2007). While this contradicts neoclassical migration theory in which decisions were based solely on employment and income (Sjaastad, 1962), younger generations have expressed demand for a larger suite of amenities, with natural amenities and recreational opportunities atop many lists. It is anticipated that such amenity values will only increase in the future with growing incomes, leisure time, and population.

When discussing the appeal of living in rural areas of the PPR with local stakeholders, it was often conceived that they valued the "rural way of life" - namely pace of life, open landscape, outdoor-recreation opportunities, sense of community, and agricultural traditions. It was those aspects that related to quality of life in the eyes of local residents. This signifies that quantitative growth is not necessarily better. Recent experiences in northwestern North Dakota in the current oil and gas boom provide abundant supporting evidence. While employment and income are on the rise, so too are crime rates, road congestion, and cost of living. Those trends show that the overall effect of quantitative growth on well-being is, at best, ambiguous. To unambiguously serve the public interest, local rural-development policies must raise living standards, including pay and the quantity and/or quality of local amenities (Power and Barrett, 2001).

Concepts of sustainability and resiliency also are cemented into rural community health. Agriculture continues as a volatile industry experiencing booms and busts. This volatility has increased recently as prices are influenced by expanding global markets and both foreign and domestic legislation. Additionally, new fears arise that farmers are setting themselves up for another bust in the near future. The identified recipe for past bust cycles - financial leveraging in conjunction to debt structure - is starting to occur (Henderson and others, 2011; Henderson and Akers, 2012).

In recent decades, agricultural and regional economists have emphasized the economic diversity of rural places and negated long-term prosperity with static notions of sector prosperity (Barkely, 1993; Johnson, 1997, 2001; Isserman, 2001; Irwin and others, 2010). When speaking to two county commissioners in rural farming counties of Minnesota, one seemed much more convinced his county was in a healthy state, noting the presence of a packing facility and small-engine manufacturing plant, both of which were doing well and continuing as major employers. This response exemplifies the value of diversification to sustainable economic health. An important message on this front was documented by agricultural economists Wagner and Deller (1998), in which they suggested 
"policymakers pursue short-run strategies within the long-run policy of diversification," and "diversification policies should be viewed as the long-run envelope of the region's short-run efforts." In that respect, the simultaneous pursuit of growth (through specialization) and stability (through diversification) are not contradictory when viewed in the terms of short and long run. Our findings reiterate the need to consider long-term health when devoting resources to short-term growth. It is fine to have short-term strategies geared towards specialized growth; the key for long-term health, however, is to have diversity within those strategies.

Our conversations with local stakeholders identified fears regarding the decline in municipal revenues following land transfers between private owners and government and nonprofit agencies. The U.S. Fish and Wildlife Service (USFWS) is the largest federal landowner in the PPR. While tax-exempt, the Refuge Revenue Sharing Act (RRS) of 1935 allows the USFWS to make annual payments to local governments in areas where fee-title purchases have removed land from the tax rolls. Review of public documents shows, however, that such payments are on the decline. Authorized RRS payments are based on the larger of 75 cents per acre or 0.75 percent of the fair market value of the land, yet 2010 RRS payments to PPR counties equated only to 22.9 percent of that authorized level.

While tax revenues might be in decline for some public lands, one must also consider the cost side. Conserved open space can require fewer local government services when compared to other land uses, and thus a lower overall cost. Road infrastructure and maintenance form one example. For perspective, oil wells in northwest North Dakota typically require around 2,200 semi loads to service the well over its production lifetime (Yamanaka, 2012). Similar infrastructure costs were echoed by a county commissioner also noting the road and bridge damage accruing from overloaded grain trucks traveling county roads. Therefore, the net fiscal effect of government land acquisition may be lower than initially perceived. Additionally, conserved lands produce a variety of ecosystem services that can affect a county's budget sheet. For instance, conserved lands provide better soil and nutrient retention than tilled cropland (Gleason and others, 2008), which in turn, can impact water quality and amount of treatment necessary to meet drinking water standards. Water-storage capacity is another example in which protected wetland catchments mitigate damages from storm surges. Overall, local municipal revenue streams continue to be real and important areas of concern; one also must factor in the costs associated with various land uses.

In summary, agriculture has long been the economic engine of the region and remains important not only economically but also socially and culturally. However, this report reveals the health of the agricultural community in the region is interconnected in a number of ways with the rural nonfarm economy. This is the case now, possibly more than ever. Once, it was believed that a strong off-farm economy was dependent on a strong farm economy. Now, research has shown that a strong farm economy and the perseverance of family farms are just as, if not more, dependent on a strong off-farm economy and labor market. These findings suggest that local governing officials looking to support agriculture in the community must also invest their time and resources in strengthening the nonfarm rural economy. The off-farm economy is powered by demand for goods and services. At a local scale, this involves spending from local residents and outsiders attracted to the area. In order to sustain or increase such demand, local officials must take into consideration their area's endowment and the reasons people enjoy living in or visiting the area. It is well-documented that people choose to live in an area based on economic opportunity (that is, jobs, wages, and potential clientele) and area amenities such as schools and other public services, environmental conditions, landscape aesthetics, and outdoor-recreation opportunities. Policy makers must think holistically and understand the linkages between their decisions and aspects of community well-being.

\section{So, where does conservation in the PPR go from here?}

Given the prominence of farmland and conservation programs in the PPR, future land use will be dictated largely by farm policy and relative funding levels for conservation. As stated by one local stakeholder, "It comes down to simple economics. Funding levels and payments for conservation will have to become competitive with crop prices." The federal government, through programs like the CRP, is the major source of funding for conservation. With tightening fiscal budgets and details of a new farm bill being heavily debated, the future of federal investment in conservation is uncertain, with most signs pointing towards a decline. The 2011 cumulative enrollment in the CRP across the four PPR states was the lowest acreage total since 1989 (U.S. Department of AgricultureFarm Service Agency, 2012). It also represents the fourth consecutive year in which CRP acres have decreased.

High commodity prices have driven the price of land in the PPR to new heights, creating new dynamics for conservation investment. One conservation program director noted, "Our [traditional] business model no longer works." Conservation organizations have had to rethink their approach, establish new and strengthen existing partnerships, and become more innovative in their land-management policies. Contemporary conservation activities increasingly are conducted by publicprivate partnerships, a form of land conservation virtually unknown prior to the 1970s (Endicott, 1993). This is certainly the case in the PPR, where many nonprofits work hand-inhand with public agencies such as the USFWS and state fish and game agencies. Given the rising costs of conservation, those relationships likely will become stronger in the future. 
In addressing economic concerns, organizations have become more receptive to "working lands" programs. That approach includes offering grazing and haying contracts, recreational opportunities, and programs such as grassland banking, which incentivize rotational grazing. Such programs are designed to keep local producers in business and to maintain rural livelihoods, yet still meet ecological objectives. Additional revenues received by an organization supplement its overall budget, which includes costs associated with staffing, land stewardship and restoration, and in some instances, payment of local property taxes. With rising program costs and concerns over local revenue and employment, this mode of conservation is likely to continue into the future.

One conservation officer in the Dakotas noted he has observed both good and bad trends with respect to conservation. On one hand, he has observed conservation norms trending upwards - that is, livestock producers implementing much more sustainable grazing practices and farmers moving increasingly toward no-till practices as the ranchers and farmers have become more soil conscious. On the other hand, the conservation officer noted high commodity prices have made it profitable to put even very marginal lands into production. For the most part, such lands typically are ecologically sensitive, and this second trend raised a concern echoed by others in separate conversations: that it is far less cost-efficient to have to restore habitat than it is to protect it in the first place.

Conservation in the PPR, as in other places, will continue to be influenced by short-term economics. Folks in the region and beyond need to understand the dynamics both of production activities and of land conservation. It will be paramount for organizations, agencies, and municipalities to think more long-term to be truly cost-efficient. Future legislation regarding farm policy and energy dependence will continue to shape evolution of the Prairie Pothole Region landscape. 



\title{
Introduction
}

\author{
By William Gascoigne
}

Rural America has changed dramatically over the last century, experiencing both times of prosperity and decline. Over half of the U.S. population lived in a rural area at the start of the 20 th century, with only 20 percent residing in a classified rural area today (U.S. Census, 2010). The outmigration of younger populations from rural communities remains a constant issue for local governing officials. A declining tax base and concurrent rising costs to repair aging infrastructure adds another challenge to the policy decision framework. Reduced enrollment has forced schools to close or merge with other districts. Farm consolidation and technical advances have reduced the demand for local labor (Cochrane, 1993; Johnson and Rathge, 2006; White, 2008). On the positive side, record-high commodity prices have amplified farm income to new heights. These increased revenues can lead to farmers spending additional money within the region, while at the same time increased transportation of product has impacted local infrastructure such as roads and bridges. These dynamics present a challenge for municipal leaders, who are charged with promoting economic development (short- and long-term) and balancing municipal spending, while at the same time maintaining the rural character and way of life that is so important to area residents.

The Prairie Pothole Region (PPR) of the U.S. encapsulates most of the Northern Great Plains, including parts of North Dakota, South Dakota, western Minnesota, northern Iowa, and northeastern Montana. For the report, the regional boundaries of the PPR are defined by those designated by the Prairie Pothole Joint Venture ${ }^{1}$; however, for this analysis the PPR portion of Montana is excluded given various data limitations. The PPR is defined largely by its rural character. Of the 163 counties within the PPR, 148 are classified as nonmetro (USDA-ERS, 2003). This region has experienced extensive land conversion over the last century, with native prairie habitats replaced by agricultural lands. As of the mid-1990s, prairie grasslands have been identified as North America's most endangered ecosystem (Samson and Knopf, 1996). The region faces continued land-use dynamics as oil and gas production reaches new heights and agricultural production is influenced by growing global markets, increased demands for biofuel feedstocks, and technological advances that alter what, where, and how crops are planted.

\footnotetext{
${ }^{1}$ Given the format of data, counties boundaries identified by the Prairie Pothole Joint Venture were used to define the PPR and are displayed in Appendix A. Some portions of included counties fall outside of the actual PPR boundary.
}

With record-high commodity prices, some fear the endangered status of the prairie will only heighten as farmers look for new cropland acres. The historic volatility of commodity prices has raised concerns over the long-term impacts of such land-use change. The economic health of rural communities in agricultural regions has been inextricably linked to the 'boom and bust' cycles of commodity markets. A turbulent global economy and tightening fiscal environment at home have people at all levels wondering if a bust cycle is imminent. Given the uncertainty, fears have arisen over the intensity of land conversion to row-crop agriculture and the resiliency of nearby rural communities. Additionally, oil and gas production has grown exponentially, with over 8,200 petroleum wells in production within the Williston Basin of North Dakota (Mason, 2012; North Dakota Industrial Commission, 2013).

Further, the U.S. Department of Agriculture's (USDA) Conservation Reserve Program (CRP) - a cropland retirement program with close to 4.8 million acres in the PPR enrolled as of 2010 - faces an uncertain future in the upcoming Farm Bill. This uncertainly is compounded by the fact that a large majority of CRP enrollment contracts are slated to expire by 2017 (USDA-FSA, 2011). Along with reducing soil erosion, increasing nutrient retention, and sequestering millions of tons of atmospheric carbon, the CRP has provided improved habitat conditions for a wide array of species (Johnson and Schwartz, 1993; Riley, 1995; Carmichael, 1997; Swanson and others, 1999; Niemuth and others, 2007; Reynolds and others, 2007; Gleason and others, 2008). In turn, wildlife-related recreation levels have increased in many parts of the PPR, and with that, money spent within local communities (Bangsund and Leistritz, 2003; Bangsund and others, 2004; Sullivan and others, 2004). Land-use change will undoubtedly have an impact on rural communities and the potential socioeconomic effects must be reviewed and discussed.

Contemporary resource-management and ruraldevelopment planning increasingly emphasize the need for diversification and integration of resource-extractive industries with nonmarket-based recreational and amenity values that also tie into quality of life (Kwang-Koo and others, 2005). Many PPR communities are facing the challenge of promoting immediate economic growth while balancing long-term development and well-being. Some land covers such as perennial grassland provide the majority of their economic benefits indirectly. For instance, they can provide reduced runoff and 
enhanced water quality (reducing treatment costs), more sufficient mitigation to flooding and storm surges (lessening potential damages to crops, homes, and businesses), superior wildlife habitat and resultant recreation (bringing in outside money to rural areas). These indirect relationships often conceal or underplay the benefits of nonproduction lands and result in their support losing ground in policy discussions.

Ultimately, each community is unique in its environmental, social, economic, and fiscal endowments. One rural-development policy may work far better in one community than another, given their unique character. In addition, rural-development issues - migration patterns, job growth, balancing tax sheets - are diverse in themselves, although there can often be parallels. The balance between agricultural production, natural resource conservation, and rural community well-being is the lifeline of this region. It is the goal of this report to qualitatively and quantitatively discuss the economic impacts of land-use decisions in rural areas, with particular focus on the PPR. In doing so, research is investigated and findings are highlighted regarding the relationship between landscape conditions and rural community well-being. This study synthesizes empirical, crossdisciplinary research findings, includes primary economic contribution analyses, and is supplemented with stakeholder viewpoints expressed during informal conversations.

The report is organized into three chapters. Chapter 1 describes the historic and current land use in the PPR. The chapter includes a discussion on the evolution of farming in the region, insight into the expanse of oil and gas production, a map of perennial habitat proportions by county, and a discussion on the status of the CRP. Chapter 2 describes the economy of the PPR and economic linkages to the landscape. The chapter discusses the role of the farm economy and reveals the economic contribution of various activities associated with conserved-habitat acres. Chapter 3 focuses on rural development in the PPR and how land-use decisions affect various rural well-being attributes. This report concludes with an executive summary that includes a synthesis of lessons learned and a discussion on the future of conservation in the PPR. 


\title{
Chapter 1: Land-Use Dynamics in the Prairie Pothole Region
}

\author{
By William Gascoigne
}

The Northern Great Plains is a country of grass, space, and sky (Flores, 1996). The natural landscape was an environmental anomaly to early settlers coming from the south and east. Historically, the landscape of the PPR was composed primarily of short-, mixed-, and tall-grass prairie, interspersed with a wide variety of wetland ecosystems, and was once one of the largest grassland-wetland ecosystems on earth (Prairie Pothole Joint Venture, 2005). The ecological makeup of the region provided essential habitat for a wide array of species. Early western settlers noted the abundance and diversity of wildlife and its potential for hunting and grazing (Flores, 1996; Duebbert, 2003). The PPR (fig. 1-1) is still known for its ecological significance, producing 50-80 percent of North America's waterfowl, while only accounting for 10 percent of the available breeding habitat (Batt and others, 1989).

The PPR landscape also provides the necessary inputs for certain agricultural production. With the onset of western expansion, native prairie grassland was cultivated and wetlands were drained. Prime soil areas in the river valleys were the first to be cultivated, mostly planted to wheat. Some of the wheat farms, called bonanza farms, grew to enormous size ranging from 3,000 to over 75,000 acres (Herman and Johnson, 2008). Since that time, agriculture has evolved in the region in terms of farm size, crop mix, and certainly planting technology. With the evolution of the industry has come additional conversion of native prairie grasslands and wetlands. Native prairie is one of the most endangered ecosystems in North America and has undergone the greatest reduction in size of any ecosystem on the continent (Samson and Knopf, 1996). Recently, conversion rates of native prairie grassland to cultivated cropland have been higher even than historic averages in some PPR counties, reaching upwards of 3 percent (Stephens and others 2006; Stubbs, 2007). The intensity of land use conversion of late has even been brought forward to Congress through field hearings and constituent correspondence (Stubbs, 2007).

The vast network of agricultural operations interspersed among natural and commonly sensitive habitats has made the PPR an attractive area for conservation investment. The largest federal cropland retirement program - the CRP — has restored millions of private acres since its inception in the mid-1980s, with North and South Dakota consistently ranked in the top ten for total CRP acres. Enrolled acres, however, have been on the decline since 2007 and likely will decline further if program payments are not adjusted to keep up with rising commodity prices (Hellerstein and Malcolm, 2011).
A vast majority - 95 percent - of the lands in the PPR remain in private ownership. Of that in public ownership, state government and federal government agencies own and manage around the same amount of acreage, at about 1.2 million acres each. Of those acres in federal ownership, a large majority are owned and managed by the U.S. Fish and Wildlife Service (USFWS). The 1.03 million acres owned by the USFWS still only constitute 1.1 percent of the total land in the PPR. The National Wildlife Refuge System (NWRS) consists of public tracts that are managed for fish and wildlife species, while routinely incorporating multiple uses such as hunting, fishing, and wildlife viewing. There are 63 National Wildlife Refuges (NWR) in North Dakota alone, more than in any other state in the country.

Oil and gas development in the Williston Basin of North and South Dakota has increased rapidly, and industry experts are predicting the Bakken Formation to become the largest oil field in U.S. history (Mason, 2012). With expanding hydrocarbon production has come an increased demand for inputs, such as gravel, water, and sand, road and delivery infrastructure, and housing. Fragmentation of the landscape and its impact on wildlife populations, in particular, is a major concern of public land managers.

The current dynamics of land-use change in the PPR are immense. With rising demand for food, fiber, and fuel (especially domestically produced), more and more lands have become dedicated to commodity production. Farm-operation structure and production practices have evolved as well. The socioeconomic impacts of this land-use change are extensive (and discussed in more detail in chapters 2 and 3). This chapter provides a comprehensive summary of land-use change taking place within the PPR, as context to the discussion in the following chapters. In particular, the chapter outlines the evolution of farming in the PPR, the boom of oil and gas production, and the current distribution of perennial habitat acres. A discussion regarding future land-use predictions concludes this chapter.

\section{Farming in the Prairie Pothole Region}

Agricultural operations across the country have changed drastically over the past century. Early 20th century agriculture in the U.S. was labor intensive and responsible for employing close to half of the U.S. workforce (Dimitri and others, 2005). Production predominantly took place on a large number of small farms that averaged producing five different commodities during a growing season. That pattern contrasts 


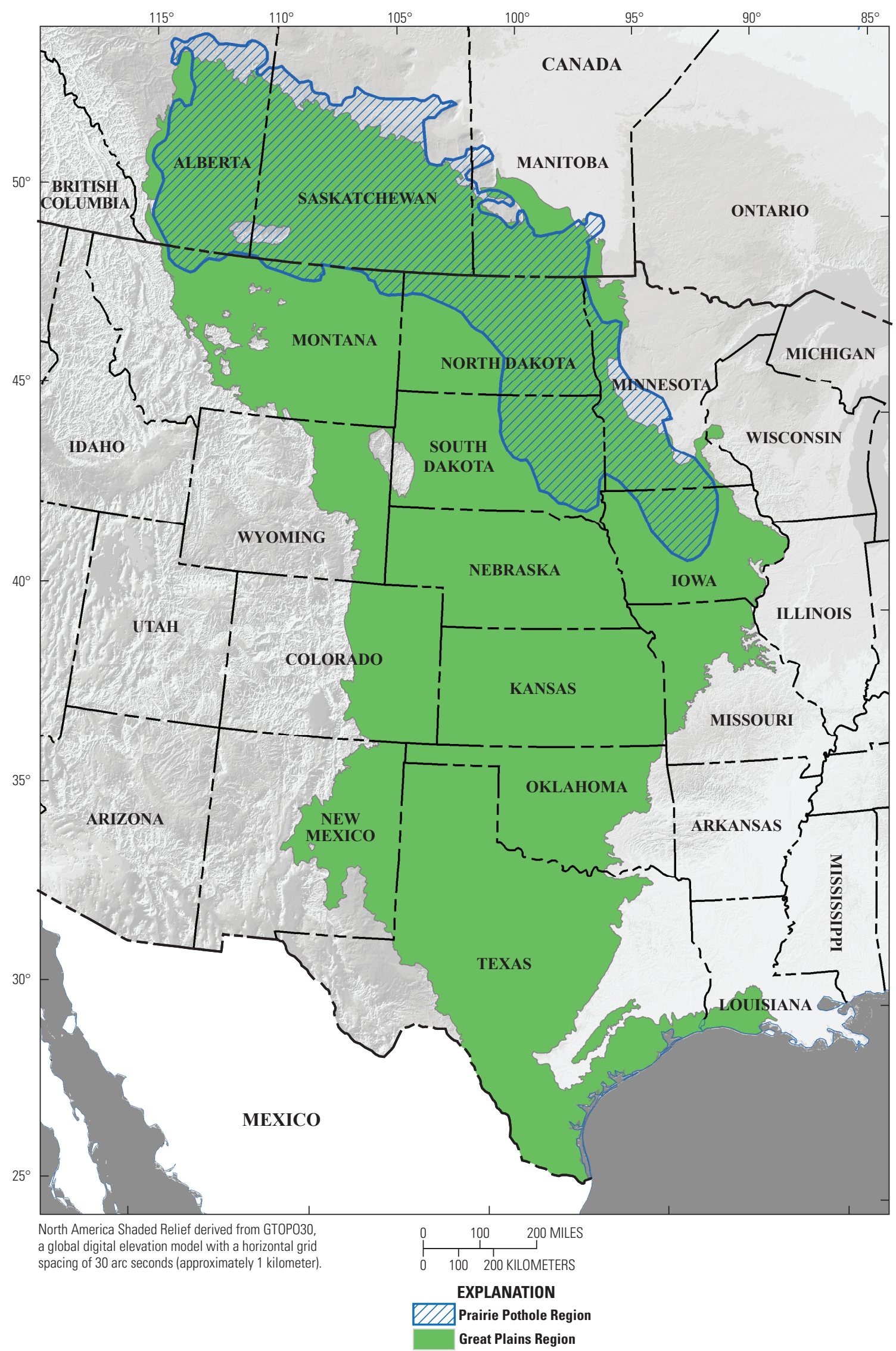

Figure 1-1. The Great Plains Region and Prairie Pothole Region of North America. 
dramatically with the agricultural sector of today, in which a high majority of production takes place on a small number of large, specialized farms (averaging only about one commodity per farm in year 2000) in rural areas where less than a fourth of the U.S. population now lives (Dimitri and others, 2005). The need for traditional farm labor has declined with the advancement of machinery, and farm price and income policies have reduced the risk of depending on returns from only one or just a few crops. All of this has taken place with almost no variation in the total amount of land being farmed. Figure 1-2 shows that the counties within the Great Plains, including those in the PPR, still have a very high percentage of their land in farms.

Overall, 90 percent of both North and South Dakota's total land area is in farmland, ranking both states in the top five in the country for this category. Of these farmland acres, 69 and 43 percent, respectively, are devoted to cropland production. Iowa also ranks in the top five in the country for total land area in farmland with an estimated 86 percent, of which 86 percent routinely is planted to crops (USDA-ERS, 2012).

Agriculture in the PPR over the last century has a unique history, going back to the bonanza farms in the Red River Valley originating in the late 1800s and lasting until the 1920s (Dahl and Allord, 1997). After years of drought, low grain prices, and competition for the labor force, those relatively large farms that typically concentrated on producing wheat gave way to the smaller family farms that had lower overhead, more diversification, and ultimately less risk. Over time, with expanding markets and transportation infrastructure, advances in crop and machinery technology, evolution of farm policy, and growing demands for various crops, the average number of commodities per farm has declined in the region. Once producing 7-12 commodities, the average producer in the PPR is now only planting 2-5 commodities (J.C. Hadrich, Colorado State University, custom query from North Dakota Farm Business Management Association 2010 Data Set and State Report, written commun., 2012). Table 1-1 displays the trends in number of farms, land (acreage) in farms, total cropland acres, harvested acres of corn (Zea mays), wheat (Triticum sp.), and soybeans (Glycine max), and lands enrolled in the CRP across the four PPR states over the last half century.

In each of the PPR states considered in table 1-1, the number of individual farms has decreased considerably since 1959. North Dakota, South Dakota, and Iowa have recorded fewer and fewer farms with each passing decade. The number of Minnesota farms decreased by nearly 65,000 (44 percent)

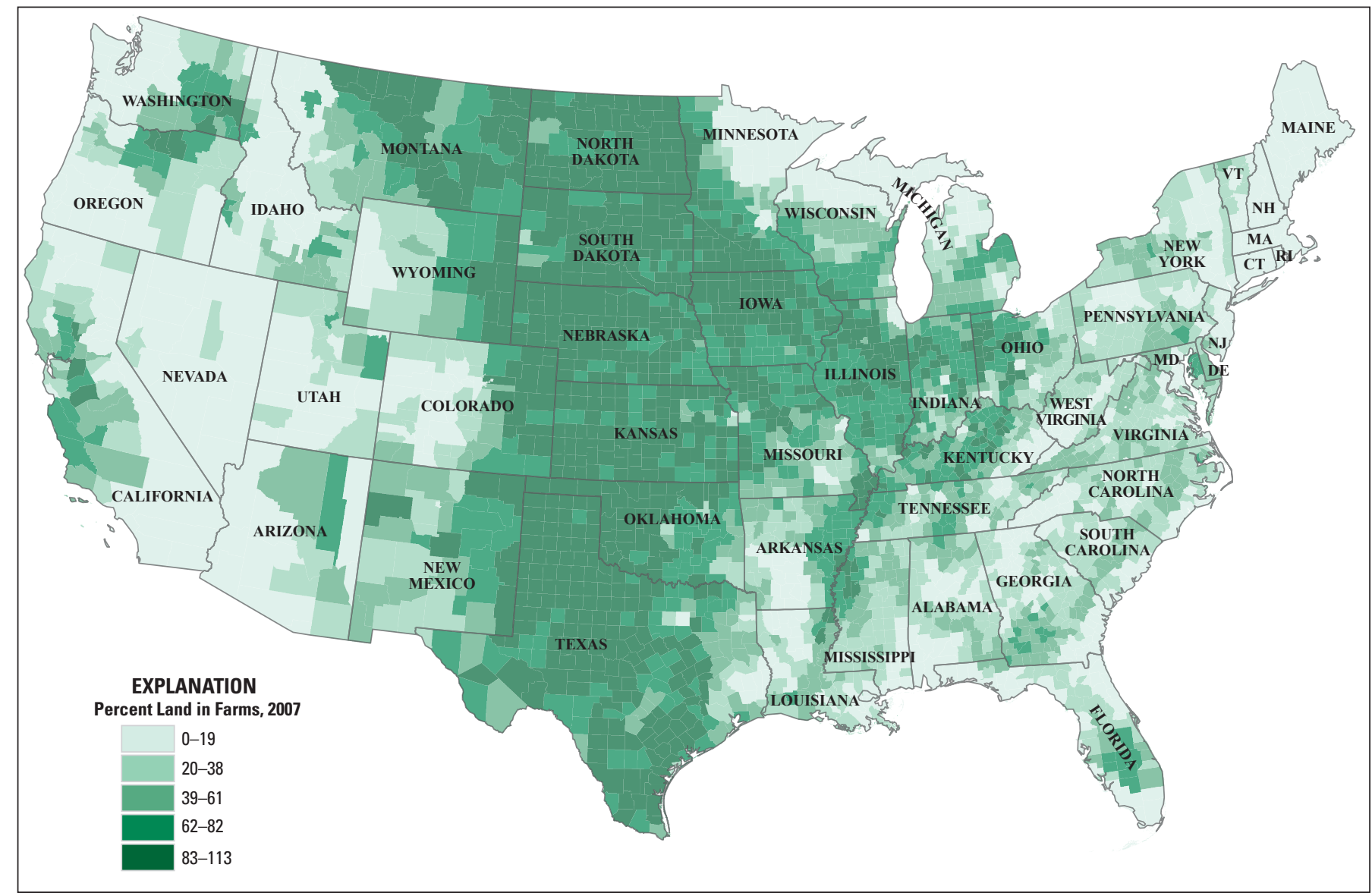

Figure 1-2. Percentage of land in farms by county for the U.S., 2007. Modified from U.S. Department of Agriculture Economic Research Service, Atlas of Rural and Small-Town America (2011b). Note: The indicated proportion of land area in farms may exceed 100 percent because some operations have land in two or more counties, but all acres are tabulated in the principal county of operation. [Abbreviations here include United States mail-code state abbreviations] 
Table 1-1. Farmland statistics for North Dakota, South Dakota, Minnesota, and lowa from 1959-2007.

[Abbreviations: NA, data not available; CRP, Conservation Reserve Program]

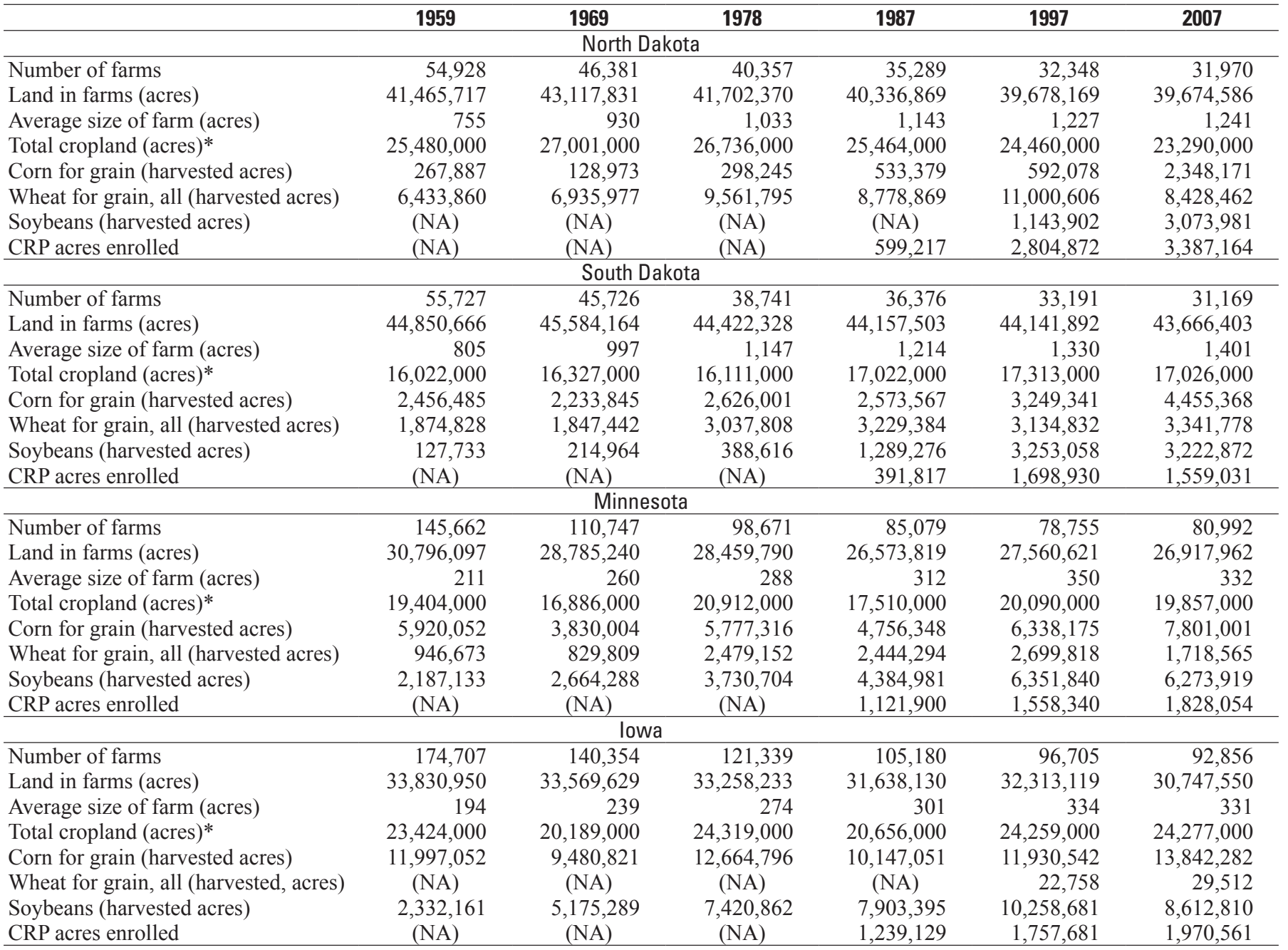

Source: U.S. Department of Agriculture, Agricultural Census Data.

*Data for Total cropland acres refer to cropland used for crops and includes cropland harvested, crop failure, and cultivated summer fallow. Data do not contain acres of cropland idled and cropland used for pasture. These data were obtained from the U.S. Department of Agriculture Economic Research Service and will vary slightly from those documented in the Census of Agriculture, which has a broader definition for this category.

since the middle part of the last century, while experiencing a relatively small increase from 1997-2007. Individual farm recordings have decreased the most in Iowa, with the state's inventory being reduced by nearly 82,000 (46 percent) within the last 50 years. However, the large reduction in the number of farms has not translated into a drastic reduction in the number of acres in farmland ${ }^{1}$ and those designated as cropland. Land in farms and those acres devoted to cropland have remained relatively constant or decreased very minimally in each of the four states when compared to 1959 levels. As of 2007, North Dakota farms encompassed 39.7 million

\footnotetext{
'The acreage designated as "land in farms" in table $1-1$ consists primarily of agricultural land used for crops, pasture, or grazing. It also includes woodland and wasteland not actually under cultivation or used for pasture or grazing, provided it was part of the farm operator's total operation. Large acreages of woodland or wasteland held for nonagricultural purposes were deleted in the referenced U.S. Department of Agriculture Census reports.
}

acres, South Dakota farms 43.7 million acres, Minnesota farms 26.9 million acres, and Iowa farms 30.7 million acres. With farmland acres at near historic levels and the number of individual farms decreasing substantially, the average size of individual farms in each state has increased with time. In the last 50 years, farm size in North Dakota, South Dakota, Minnesota, and Iowa increased by 64 percent, 74 percent, 57 percent, and 71 percent, respectively.

The mixture of crops produced across the landscape can have significant economic and ecological impacts within a region (which is the focus of chapters 2 and 3). The recent push for renewable energy from biofuels and higher-thanaverage market prices for corn and soybeans, with a growing portion of these crops being used as a bioenergy fuel feedstock, has impacted the crop mix planted by producers. Recent advances (and accompanying approvals by the USDA) in crop engineering, such as drought-resistant corn, likely will impact 
the crop mixture in the coming years. In 2007, the number of acres planted to corn in each of the four states was the highest ever recorded in their history. In the 10 years from 1997-2007, acres planted to corn increased by nearly 300 percent, or roughly an additional 2.2 million acres in North Dakota. From 2005-2007 alone, more than 3.2 million acres were converted to corn production in PPR portions of Iowa, Minnesota, North Dakota, and South Dakota, mostly coming from acres previously in small-grain production, CRP acres expiring and going back into production, and the conversion of native prairie (Brooke and others, 2009). Statistics for South Dakota show an even greater density of corn acres than the state bordering to the north. While South Dakota had 6.3 million acres less cropland than North Dakota, it has nearly double the amount of acres in corn. Each of the four PPR states added over a million new acres to corn production from 1997-2007.

Corn planting figures across the region have spiked even higher in the last few years. Compared to 2010, corn growers in 2011 planted an additional 850,000 acres in Iowa, totaling 14.2 million acres (USDA-NASS, 2011). Similarly, South Dakota planted an additional 650,000 acres of corn totaling 5.2 million acres, which is the largest percentage increase of any state in the country. Minnesota growers added 400,000 new corn acres for a total of 8.1 million, and North Dakota added 250,000 acres devoted to corn for a total of 2.3 million acres in 2011 (USDA-NASS, 2011). A recent USDA press release projects a 75-year-high planting to corn in 2012, with Iowa, North Dakota, and South Dakota expected to set new state records. North Dakota alone is expected to add 3.4 million acres to corn, up 52 percent from 2011 (USDA-NASS, 2012). Figure 1-3 displays the geographical distribution of corn production in North Dakota in 2006 and in 2011, with observed expansion in the northern and western portions of the PPR.

Soybean production in the region has also increased over time. North Dakota growers have more than doubled the amount of acres devoted to soybeans, with total annual acreage above 3 million over the last ten years. South Dakota, Minnesota, and Iowa maintained relatively constant soybean production levels from 1997-2007. However, 2011 estimates reveal increases across the four states. USDA crop production reports indicate Iowa growers planted an estimated 9.2 million acres in 2011, while Minnesota and South Dakota growers planted 7.2 and 4.3 million acres of soybeans, respectively (USDA-NASS, 2011). North Dakota soybean growers planted 4.35 million acres in 2011, a sizable increase from previous years and a new state-record high. While corn and soybean plantings expanded, ground devoted to wheat production in the PPR has decreased. From 1997-2007, the number of acres in wheat in North Dakota and Minnesota decreased by a combined 3.6 million. Figure 1-4 displays the geographical distribution of soybean production in North Dakota in years 2006 and 2011, again showing crop expansion to the west and north within the state.

With increasing yields for corn and soybeans, at a time of rising prices for the two commodities, many agronomists believe corn and soybean production will continue to swell at the expense of wheat. A North Dakota Extension specialist recently noted, "[corn] used to be about half as valuable as wheat, so you had to get twice the yield to stay even on gross returns... and with $\$ 7$ corn, it's difficult to justify it (staying with wheat)... because [corn] is two to three times higher yielding than wheat in the same environment" (Olson and Schmidt, 2011).

\section{Oil and Gas Boom in the Prairie Pothole Region}

Oil and gas production in the PPR has increased exponentially in the last few years (fig. 1-5). North Dakota recently surpassed Alaska as the number 2 producer in the nation, trailing only Texas in terms of oil volume (North Dakota Industrial Commission, 2013). In 2012, North Dakota oil production exceeded 500 thousand barrels per day (mbbl/d).

With the expansion of oil production have come many changes to the region and its rural communities. From a landscape perspective, fragmentation has been amplified as well-pad distribution and density have increased with production volume. Figure 1-6 displays the extent of well-pad development in the PPR of the U.S. and into Canada since 1925 through $2012 .^{2}$

The brown dots in figure 1-6 do not account for roads, holding tanks, and additional distribution infrastructure. New proposals have been submitted for large-scale pipelines and additional rail infrastructure for crude oil export. As of the end of 2012, there were over 8,200 active production wells in North Dakota, with close to 200 new wells going into production each month (North Dakota Industrial Commission, 2013). Some experts have estimated the potential for another 20,000-30,000 wells to be drilled in the next 10-20 years (Holywell, 2011). The carrying capacity of the Bakken Formation alone is estimated to be around 39,000 wells, with indications that it will prove to be the largest oil field in U.S. history (Mason, 2012).

The recent boom in petroleum production has brought about landscape stressors beyond well pads and fragmentation from roads. Demands for inputs such as water and sand have caused a range of new dynamics as well. Farmers are being pressured for their irrigation permits, which could result in changes in the crop mix of planted acreage or even in land going fallow (Kusnetz, 2012). The need for gravel for road networks and sand for the hydraulic fracturing process has sparked new mine development. Additionally, residential development is moving at an unprecedented rate trying to keep up with the influx of new residents attributed to the oil and gas boom. With the production projections over the next 10 years, it seems inevitable that these trends will continue to rise over the next decade and beyond.

\footnotetext{
${ }^{2}$ As noted, this map displays all permitted petroleum wells from 1925-2012. Some of these wells are no longer in production or could have been reclaimed in some way.
} 
Corn for Grain: Production North Dakota, 2006

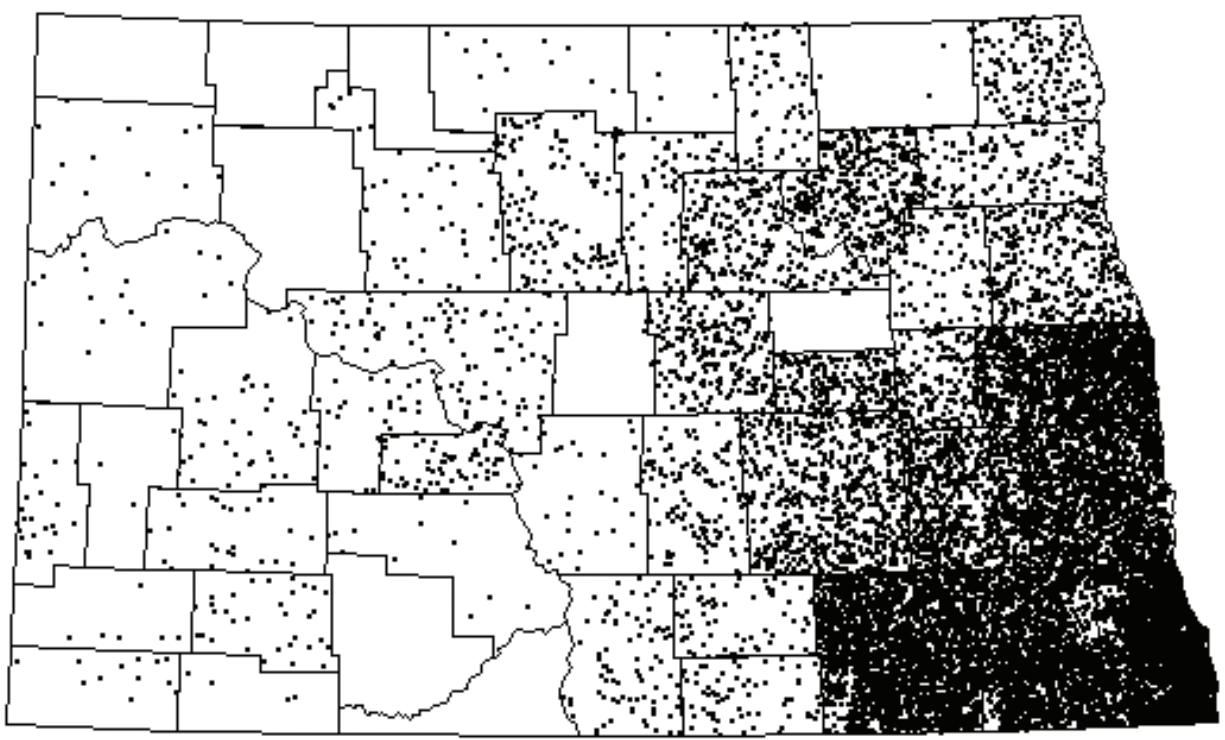

Corn for Grain: Production North Dakota, 2011

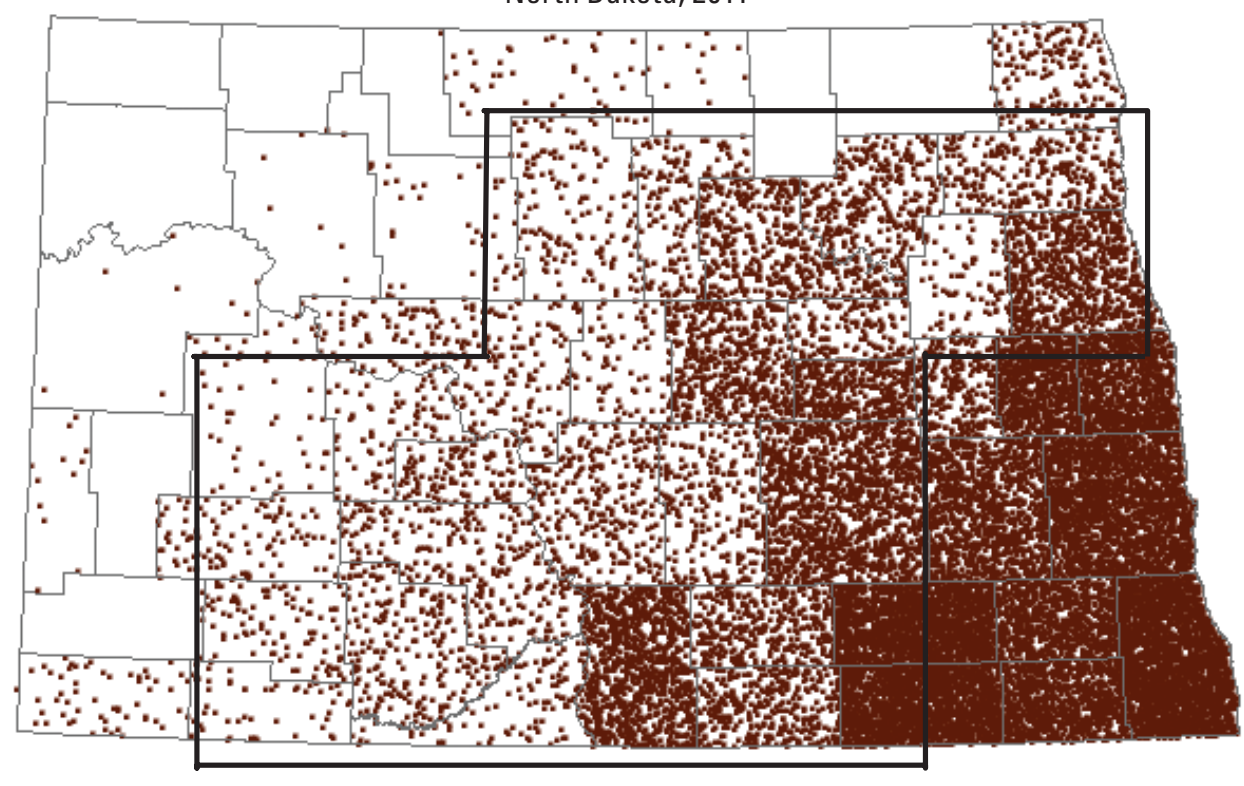

EXPLANATION

1 Dot $=10,000$ bushels. Dots randomly

placed within county. Blank counties represent none harvested or undisclosed data

Figure 1-3. Corn for grain production in North Dakota, 2006 and 2011; 1 dot equals 10,000 bushels. Dots randomly placed within county (boundaries represented by lines). Blank counties represent none harvested or undisclosed data. Box identifies area where majority of growth has taken place. Modified from U.S. Department of Agriculture National Agricultural Statistics Service, North Dakota field office (2011). 

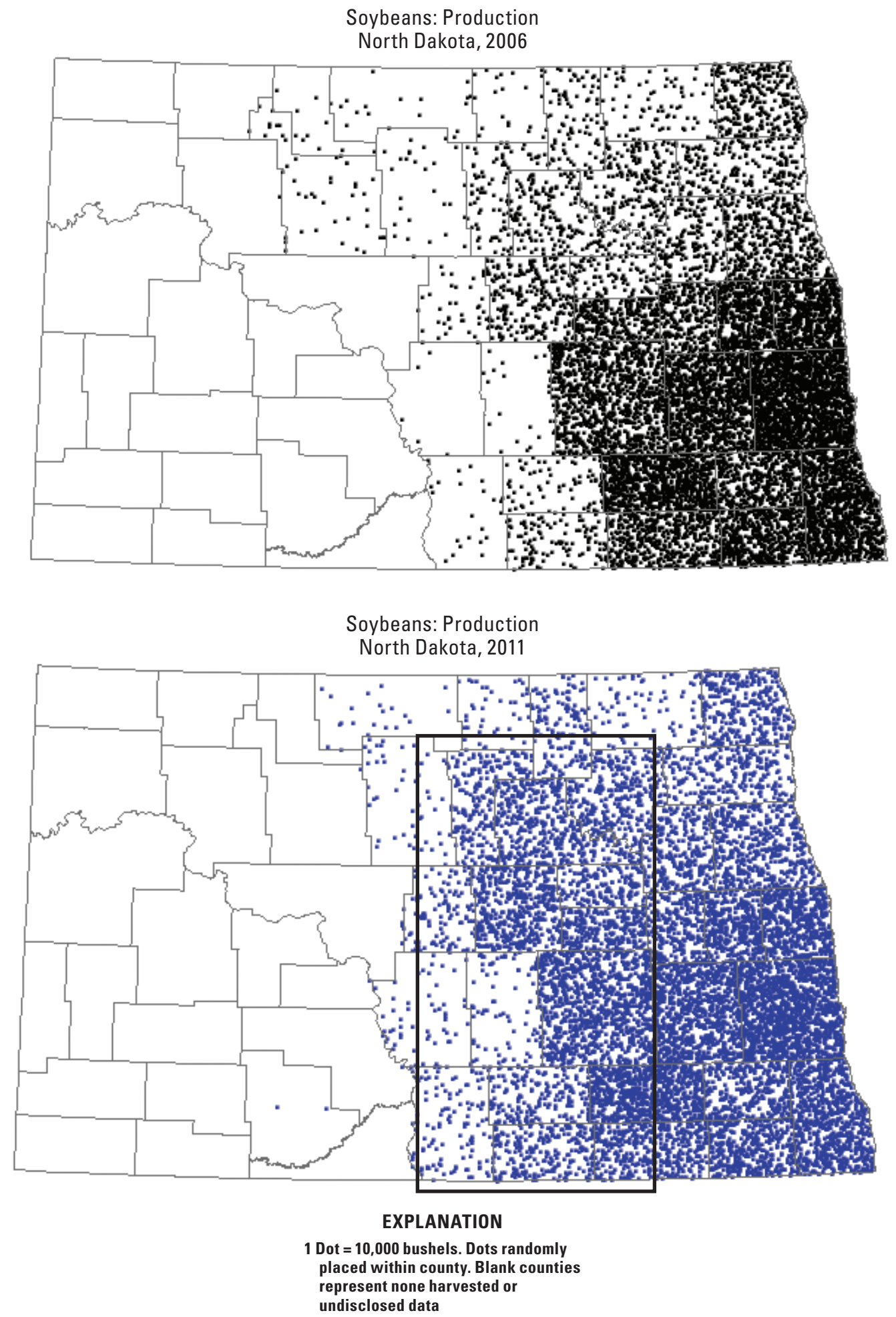

Figure 1-4. Soybean production in North Dakota, 2006 and 2011; 1 dot equals 10,000 bushels. Dots are placed randomly within county (boundaries represented by lines). Blank counties represent none harvested or undisclosed data. Box identifies area where majority of growth has taken place. Modified from U.S. Department of Agriculture National Agricultural Statistics Service, North Dakota field office (2012). 


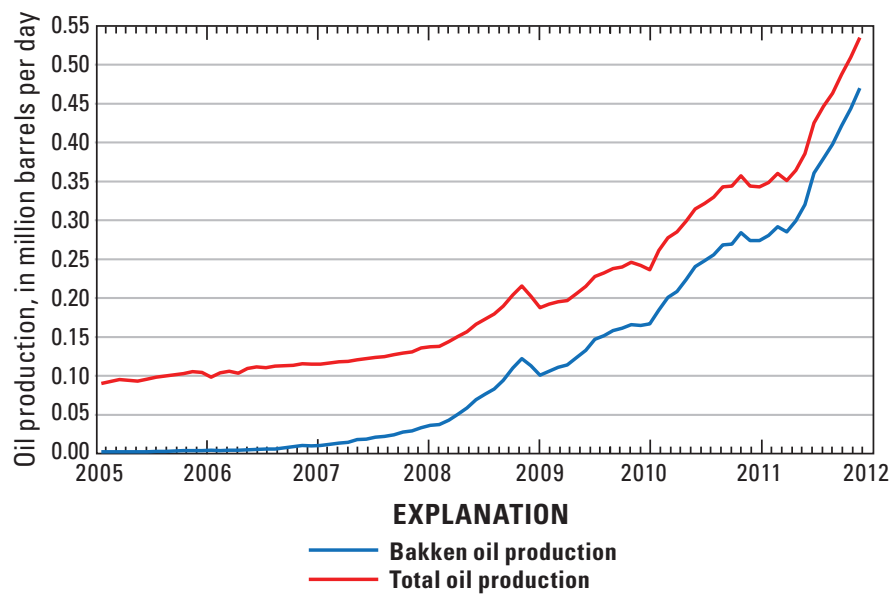

Figure 1-5. Oil production in North Dakota and within Bakken Formation, 2005-2011. Modified from Mason (2012).

\section{Perennial Habitat in the Prairie Pothole Region}

As noted, the PPR is a region that has experienced extensive land-use conversion from prairie grasslands and wetlands to lands devoted to agricultural production. A 1988 report to Congress by then-Secretary of the Interior Donald Hodel found that only about 7 million of the original 20 million acres of prairie wetlands remained (U.S. Government Accountability Office, 2007). In Iowa and Minnesota, less than 1 percent of those states' original prairie remains (Smith, 1998; Minnesota Geological Survey, 2011). The prairie grassland abundance is higher in the Dakotas; however, it estimated only a quarter of the original prairie in South Dakota is still in existence (Reynolds, 2006). Likewise, previous estimates indicate more than 50 percent of the PPR's wetlands in the U.S. have been drained or altered for agricultural production (Tiner, 1984). The ecological significance of prairie grasslands and wetlands, and the threat of conversion, has moved federal, state, and nongovernmental agencies involved in conservation to focus on the PPR.

At the federal level, the two most prominent agencies involved in conservation in the PPR are the U.S. Department of Agriculture (USDA) and the U.S. Fish and Wildlife Service (USFWS). The USDA heavily targets land in private ownership with an agricultural history, with programs typically designed around short-term and perpetual conservation easements. The USFWS owns and manages public land mostly through the National Wildlife Refuge System (NWRS) but also manages a significant amount of easements on private lands (also under the umbrella of the NWRS). The USDA's largest conservation program - the Conservation Reserve Program, or CRP — was born out of the Food Security Act of 1985 (Title XII, P.L. 99-198, 99 Stat. 1354, December 23, 1985), otherwise known as the 1985 Farm Bill, and has been reauthorized in all subsequent farm bills. The program was developed around the premise that farmers would voluntarily enroll highly erodible cropland and other environmentally sensitive acreage and convert it to a perennial vegetative cover in return for an annual rental payment. Conservation Reserve Program acreage across the four PPR states peaked in 2007 but has been declining ever since. Today, there remain more than 4.8 million acres enrolled in the program in the PPR, making it the largest conservation program in the region. Table 1-2 presents the 2007 and 2010 enrollment for North Dakota, South Dakota, Minnesota, and Iowa, with percentage change over that time. In just those three years, CRP acres in the four states declined by 18.7 percent, or roughly 1.6 million acres.

While some conservationists are critical of CRP acres in their ecological inferiority to native prairie, many have been quick to embrace the ecosystem services provided by the planted vegetation and have fought hard to keep program support. Other USDA conservation programs in the region include the Wetlands Reserve Program (WRP) and Grassland Reserve Program (GRP), yet those have a much smaller presence. Acres enrolled in the CRP are a major contributor to the distribution patterns of existing grassland habitat. CRP enrollments are typically structured as 10- to 15-yr contracts. A majority of contracts are slated to expire from 2011-2017. Table 1-3 provides the total acreage associated with those expiring contracts. It is observed that a majority of those acres are scheduled to expire in 2011 to 2013. Specifically, 2.98 million acres in the four states will expire by the end of 2013, leaving less than 2 million acres if there are no future general signups.

Hodur and others (2002) conducted a survey of North Dakota CRP contract holders to investigate land use intentions if their lands were no longer in the CRP. Survey results indicated 68 percent of CRP land would return to crop production if the program were no longer in existence. However, more than 80 percent of respondents said they would keep at least some of their land in the CRP if enrollment criteria and payments were unchanged. It should be noted that current cropland rental rates in North Dakota are significantly higher than when this survey was conducted in 2002, which might alter this response (USDA-NASS, ND, 2011). Janssen and others (2008) conducted a similar study of South Dakota CRP contract holders and found that 66 percent of respondents indicated they were unsure or not likely to reenroll in the program. Of those, 60-70 percent indicated they had intentions of converting that land back to crop production, mostly for corn, soybeans, and wheat.

Table 1-2. Enrolled Conservation Reserve Program (CRP) acreage in North Dakota, South Dakota, Minnesota, and lowa, in 2007 and 2010, and percentage change between those years. Modified from U.S. Department of Agriculture Farm Service Agency (2012).

\begin{tabular}{|c|c|c|c|}
\hline \multirow{2}{*}{ State } & \multicolumn{2}{|c|}{ Enrolled CRP acres } & \multirow{2}{*}{$\begin{array}{c}\text { Percentage } \\
\text { change }\end{array}$} \\
\hline & 2007 & 2010 & \\
\hline North Dakota & $1,970,561$ & $1,638,546$ & -16.8 \\
\hline South Dakota & $1,828,054$ & $1,640,550$ & -10.3 \\
\hline Minnesota & $3,387,164$ & $2,717,520$ & -19.8 \\
\hline Iowa & $1,559,031$ & $1,112,472$ & -28.6 \\
\hline Region total & $8,744,810$ & $7,109,088$ & -18.7 \\
\hline
\end{tabular}




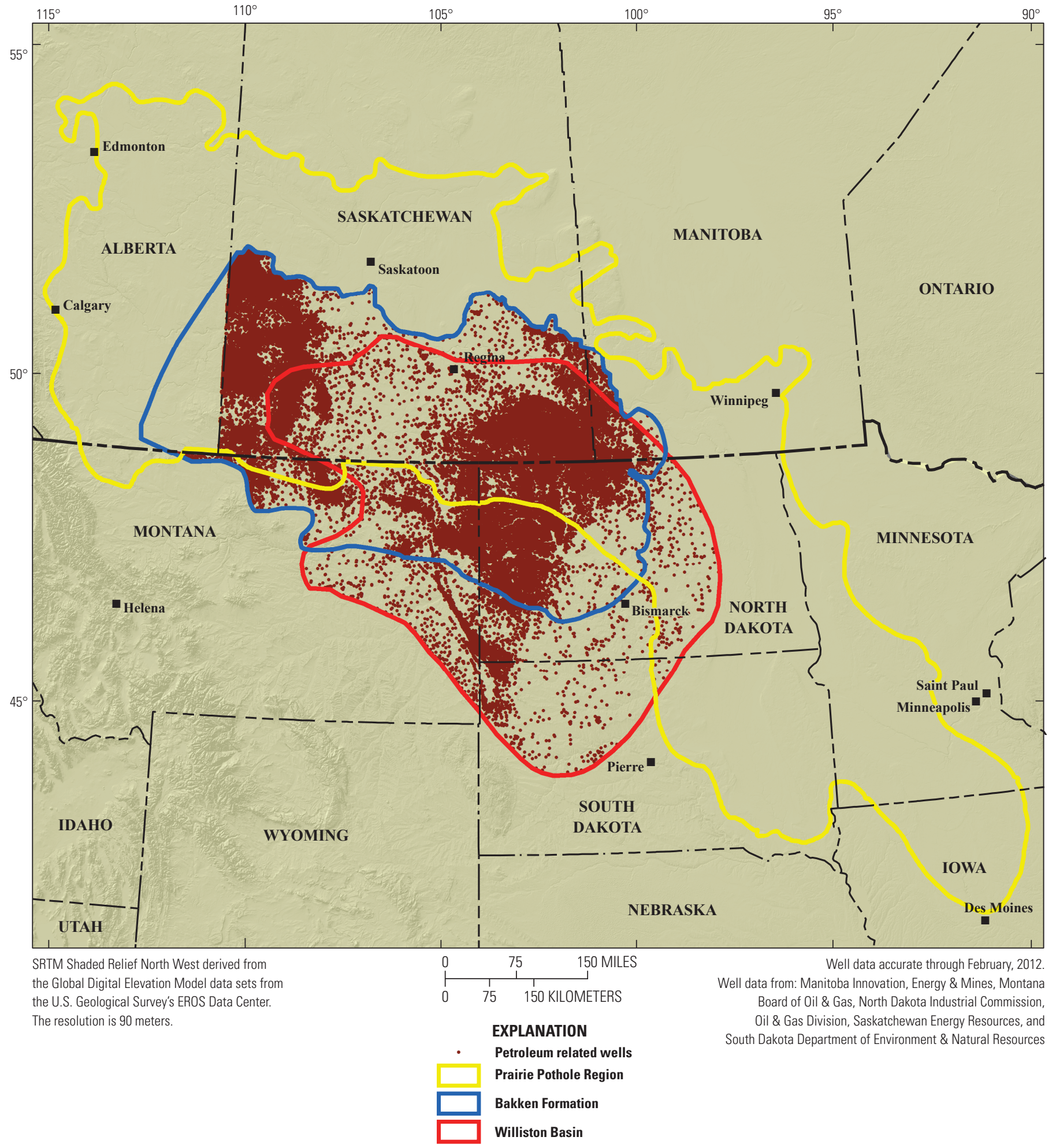

Figure 1-6. Map of the extent of the Bakken Formation and of the Williston Basin in the Prairie Pothole Region (PPR) of the United States and Canada. Brown dots represent the spatial distribution of oil wells in the region as of February 2012. Spatial well data were unavailable for the province of Alberta. Data compiled and merged by Tara Chesley-Preston, U.S. Geological Survey (2012). 
Table 1-3. Conservation Reserve Program (CRP) contract acreage expiring within North Dakota, South Dakota, Minnesota, and lowa, 2011-2017. Modified from U.S. Department of Agriculture Farm Service Agency (2011).

\begin{tabular}{lrrrrrr}
\hline & \multicolumn{7}{c}{ CRP contract expirations (acres) } \\
\cline { 2 - 7 } & $\mathbf{2 0 1 1}$ & $\mathbf{2 0 1 2}$ & $\mathbf{2 0 1 3}$ & $\mathbf{2 0 1 4}$ & $\mathbf{2 0 1 5}$ & $\mathbf{2 0 1 6}$ \\
\hline North Dakota & 386,955 & 839,965 & 258,764 & 148,535 & 53,619 & 39,239 \\
South Dakota & 125,185 & 226,911 & 107,088 & 71,874 & 45,739 & 58,037 \\
Minnesota & 127,535 & 292,429 & 130,246 & 207,841 & 101,634 & 90,803 \\
Iowa & 72,013 & 231,672 & 185,926 & 92,558 & 113,924 & 98,176 \\
Total & 711,688 & $1,590,977$ & 682,023 & 520,808 & 314,917 & 286,228 \\
\hline
\end{tabular}

Record-high commodity prices in the last few years are likely to entice an even greater proportion of landowners with expiring contracts to convert back to cropland (Hellerstein and Malcolm, 2011). That likelihood is supported by a recent modeling effort of future land conversion in the PPR based on price conditions (Rashford and others, 2010) and further supported by likely-to-bid/opt-out models that account for crop prices and rental payment levels (Hellerstein and Malcolm, 2011). Regardless of reenrollment acreage in the next few years, the CRP will remain the Nation's largest conservation program. The long-term fate of the program, however, is uncertain given rising commodity prices, tightening fiscal budgets, and uncertainties regarding details of future farm bills.

In contrast, the USFWS owns and manages mostly public lands through the NWRS. As noted, North Dakota has more NWRs than any other state in the country, with 63 . The NWRS in the PPR constitutes approximately 1 million acres dedicated to wildlife habitat. Waterfowl Production Areas (WPAs), as part of the NWRS, are found in almost every county in the PPR. The WPAs are purchased (either acquired through fee-title or perpetual easement) using revenue from the Federal Migratory Bird Hunting and Conservation Stamp (a.k.a. "Duck Stamp") and are targeted for their breeding and nesting habitat qualities for migratory waterfowl. Of all the WPAs nationwide, 95 percent are located in the PPR, constituting roughly 650,000 acres. They range in size, with the smallest less than an acre and the largest nearly 7,500 acres. The USFWS also maintains the Partners for Fish and Wildlife (PFW) program through which the agency works with private landowners to offer direct financial and technical assistance for restoring privately owned grassland and wetlands in return for habitat conservation over some contracted time period.

Although the region consists primarily of agricultural lands, there remains a significant distribution of land cover classified as perennial habitat ${ }^{3}$. Given the ecological and economic significance of these lands (discussed in detail in chapter 3), habitat and remote sensing specialists were summoned to formulate an aggregate distribution of perennial habitat acres in the PPR. Constrained by various data limitations, two separate distribution maps were produced to provide insight into general habitat cover (that is, the first map) and

\footnotetext{
${ }^{3}$ See Appendix B for land-cover classes that are included in the definition of perennial habitat.
}

acres specifically targeted through conservation efforts (that is, the second map). The first map (fig. 1-7) was produced using habitat-representative land cover classes within the most recent (2001-2006) USFWS Habitat and Population Evaluation Team (HAPET) datasets. Included classes pertained to existing grasslands (native and planted); forest and shrubs; lands used for hay production; temporary, seasonal, and semi-permanent wetlands, along with permanent wetlands such as lakes and rivers (see Appendix B for a detailed list of classes). These acres are displayed spatially in figure 1-7 and represented as a percentage of total county acres in figure 1-8.

We observe a high degree of variation in perennial habitat, with the highest percentages of perennial habitat found along the western PPR boundary of the Dakotas and on the northeastern PPR boundary in Minnesota. Counties displaying the highest percentage of perennial habitat in North Dakota include Burleigh, Eddy, Emmons, Kidder, Logan, McHenry, McIntosh, Rolette, and Sheridan. Those in South Dakota include Aurora, Brule, Buffalo, Campbell, Hand, Hyde, Jerauld, Marshall, McPherson, Sanborn, and Walworth. Minnesota counties with high proportions of perennial habitat include Becker, Mahnomen, Otter Tail, and Roseau. Counties along the shared boundary between the Dakotas and Minnesota show lower percentages of perennial habitat cover. The lowest distribution of perennial habitat is observed in the southwestern portion of Minnesota and into the northern counties of Iowa, along with some counties in the Red River Valley of east-central North Dakota and west-central Minnesota.

Given the extent of land-use change in the last six years (that is, since the USFWS HAPET data were collected), the most recent spatial and tabular data regarding federal, state, and nonprofit conservation-organization acres that largely constitute perennial habitat conservation were gathered and organized. That acreage includes federal efforts such as lands enrolled in the CRP, WRP, GRP, and the Conservation Reserve Enhancement Program (CREP); lands owned by USFWS through the NWRS along with USFWS grassland easement acres; state lands managed for recreation and wildlife production; and lands owned or under easement with NGOs such as The Nature Conservancy (TNC). (For a complete list of included acres by each state please reference Appendix B.) The distribution of these lands with a "conserved and/or protected" status is presented in figure $1-9$ as a percentage of total county acreage. 


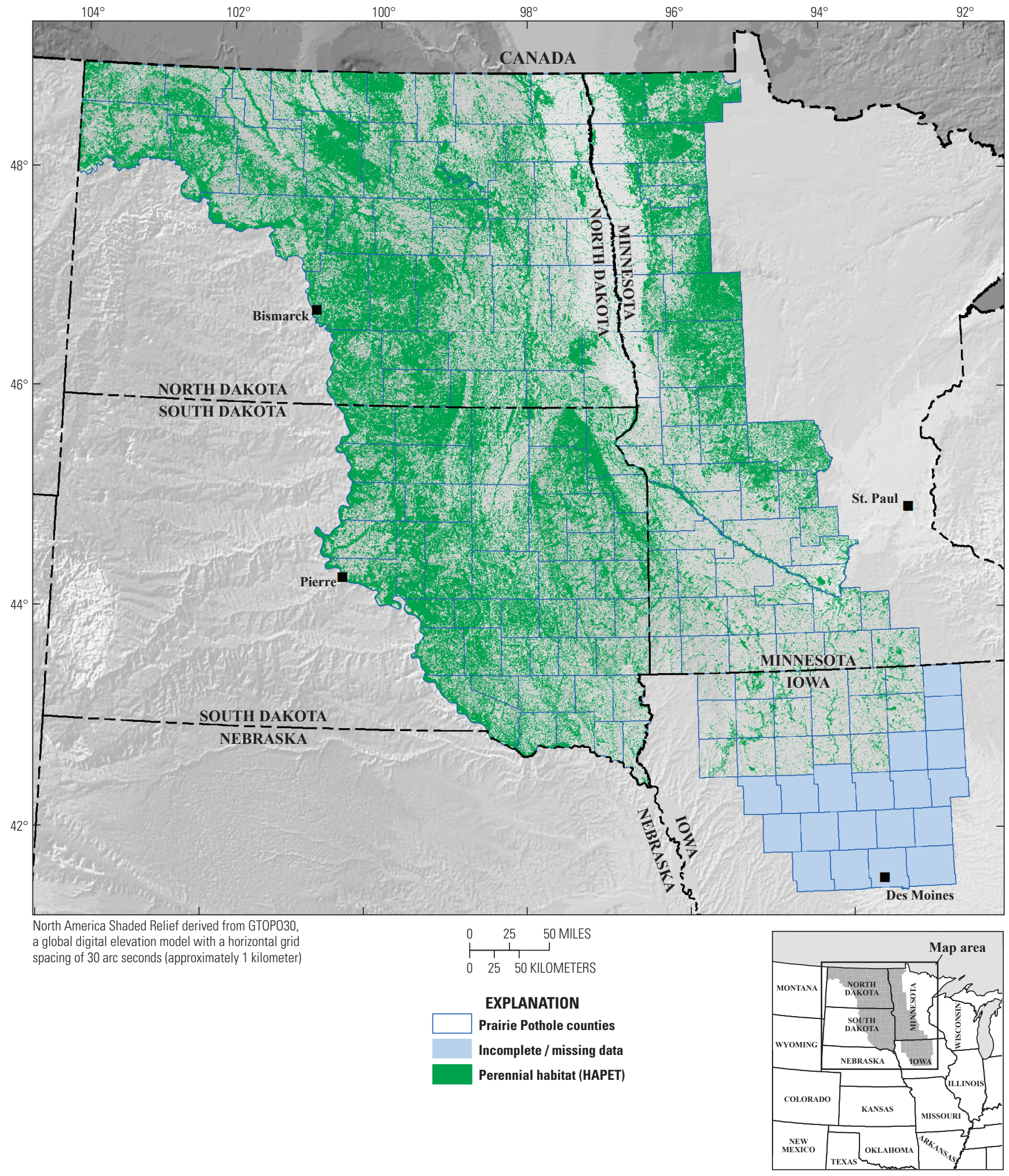

Figure 1-7. Perennial habitat distribution in the Prairie Pothole Region of the United States, based on 2006 U.S. Fish and Wildlife Service Habitat and Population Evaluation Team (HAPET) land-cover data (Fry and others, 2011). 


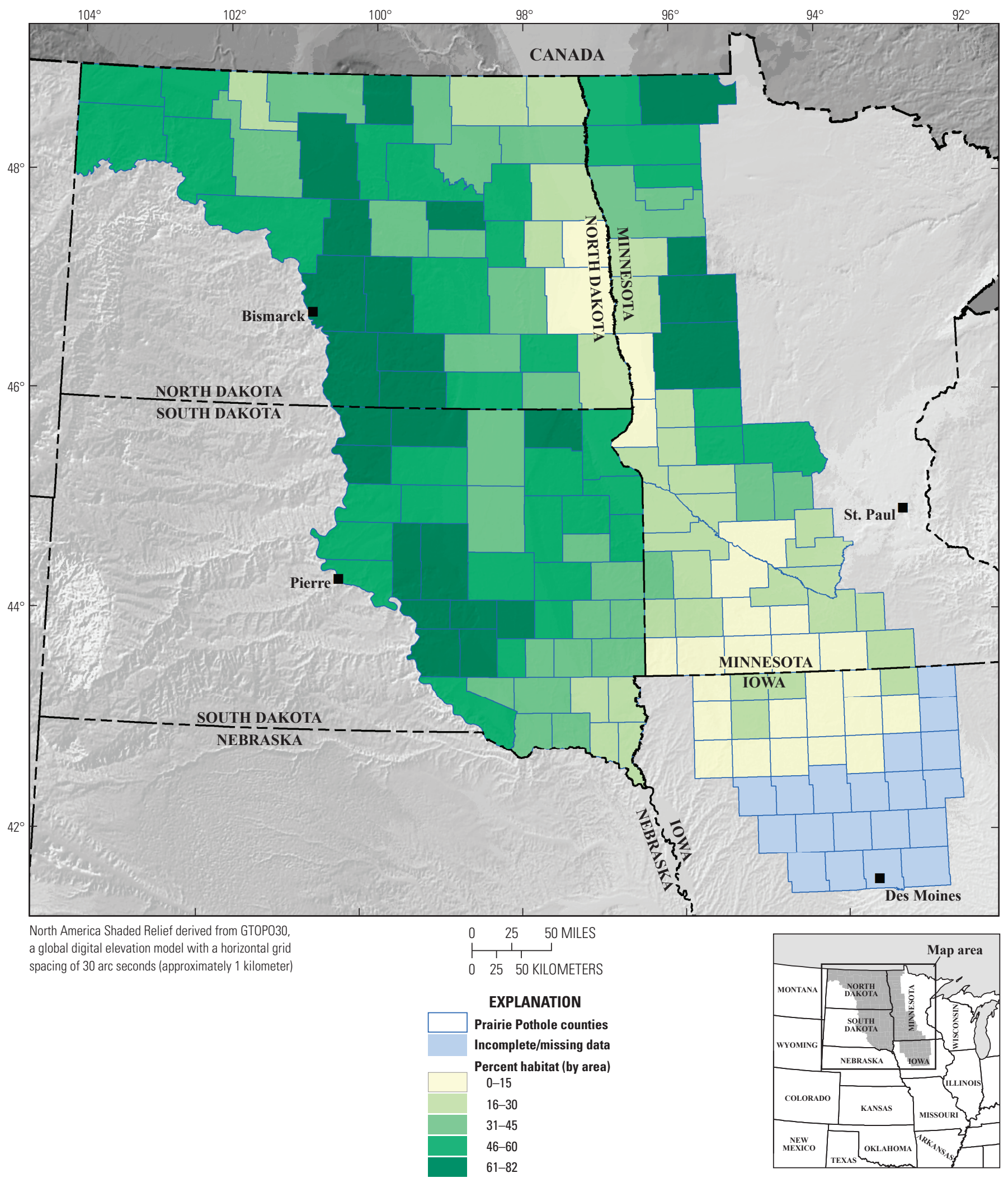

Figure 1-8. Percentage of county acres classified as perennial habitat in the Prairie Pothole Region of the United States, based on 2006 U.S. Fish and Wildlife Service Habitat and Population Evaluation Team (HAPET) land-cover data (Fry and others, 2011). 


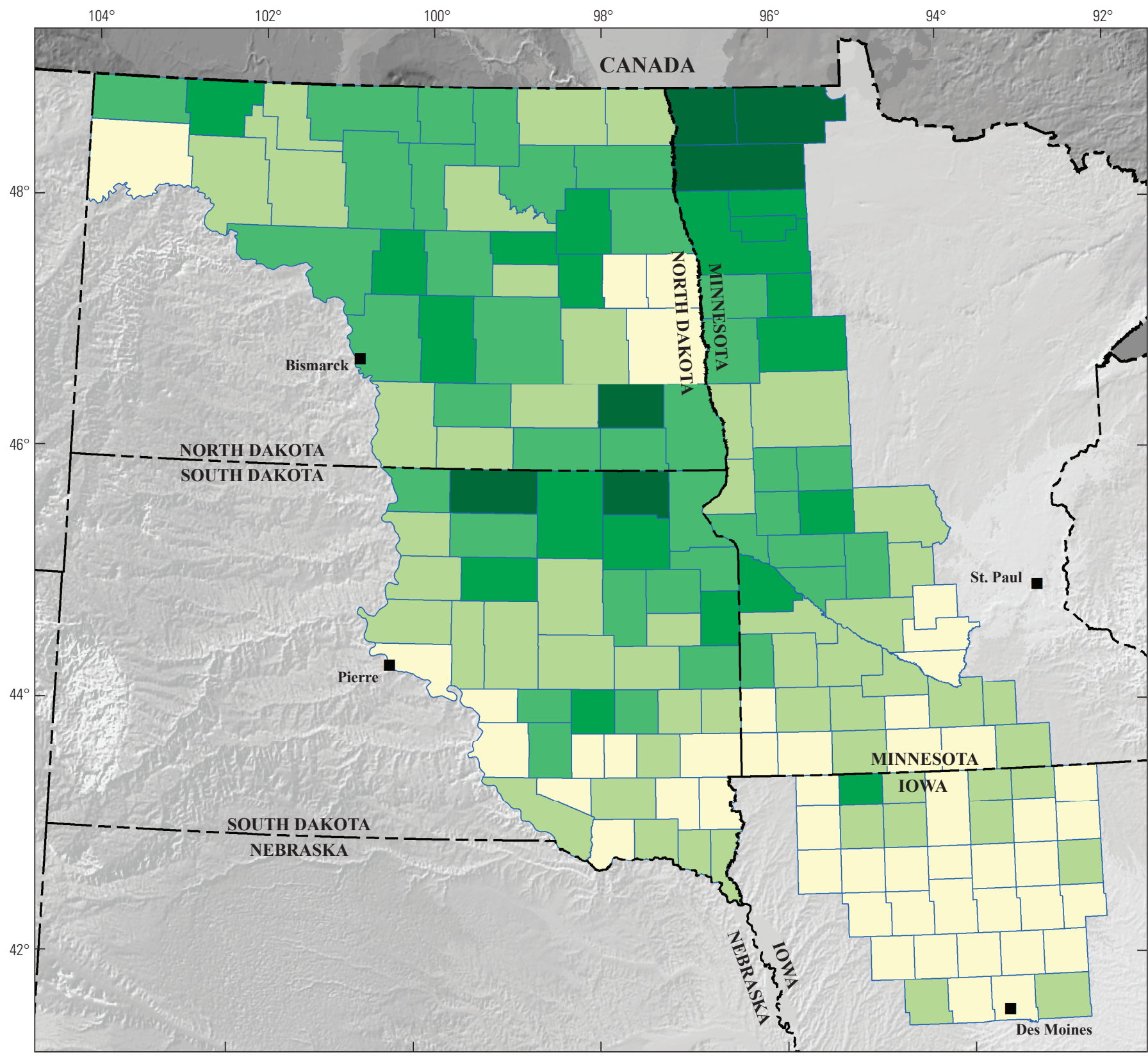

North America Shaded Relief derived from GTOP030, a global digital elevation model with a horizontal grid spacing of 30 arc seconds (approximately 1 kilometer)

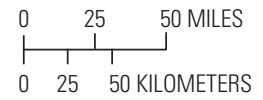

EXPLANATION

Prairie Pothole counties Percent protected or conserved

$1-5$

6-9

$10-14$

$15-20$

21-36

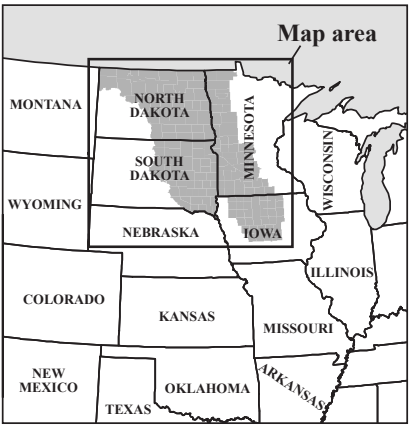

Figure 1-9. Perennial habitat acreage in the Prairie Pothole Region of the United States as defined by lands with a protected (short- and long-term) status ${ }^{1}$, conserved status ${ }^{2}$, or management for wildlife-friendly cover displayed as a percentage of total county acres. Reference Appendix B for sources.

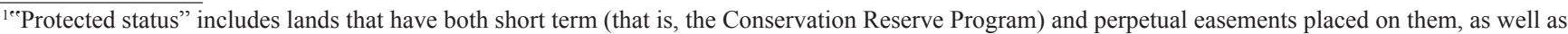
state parks, recreation areas, and other acreages that have been permanently protected.

${ }^{2 e c}$ Conserved status" refers to lands such as state timber lands that might be multi-use with managed production practices.
} 
We observe a fair amount of variation across the region, with most counties having less than 15 percent of their total acres in a conserved/protected habitat. Notable counties with the highest percentage of conserved/protected land include McPherson and Marshall, South Dakota; Ransom, North Dakota; and Roseau, Marshall, and Kittson in Minnesota. McPherson County and Marshall County in South Dakota have been a concentration point for USFWS private-land restoration efforts, with more than 100,000 acres and 50,000 acres enrolled in grassland easements, respectively. Those two counties also have strong enrollment in the CRP (roughly 28,000 acres in McPherson and 40,000 acres in Marshall) and lands owned by a federal or state agency (roughly 25,000 acres in McPherson and 40,000 acres in Marshall), which bring both counties' total percentage of lands in a conserved state to between 20-25 percent. Ransom County leads North Dakota, with around 88,000 acres in federal/state ownership and an additional 60,000 acres enrolled in the CRP. The three leading counties in Minnesota all maintain CRP enrollment of more than 100,000 acres. Marshall County (Minn.) has the most with more than 187,000 acres enrolled in the program. Additionally, Roseau, Marshall, and Kittson counties all have more than 75,000 acres in federal/ state ownership. Roseau County leads the way with more than 260,000 acres owned by the government. The three Minnesota counties have between 28 to 36 percent of their total acreage in a conserved or protected state (as defined by this study).

\section{Summary of Land-Use Dynamics}

The PPR has undergone vast change due to competing land uses. To summarize, the web of native prairie grasslands and pothole wetlands has been deemed North America's most endangered ecosystem (Samson and Knopf, 1996). Some statistics reflecting the extent of conversion noted earlier in this chapter include:

- The U.S. portion of the PPR has lost more than 70 percent of its original native prairie grassland (Young, 2008)

- By the late 1980 s only 7 million of the original 20 million acres of prairie wetlands remained (U.S. Government Accountability Office, 2007)

- Less than 1 percent of Minnesota's original prairie habitat is still in existence (Minnesota County Geological Survey, 2011)

- It is estimated that less than 0.1 percent of Iowa's original prairie wetlands remain intact (Smith, 1998)

- Only a quarter of South Dakota's original grasslands remain (Reynolds, 2006)
- Since the mid-1980s, the average rate of native prairie conversion has been 0.5 percent per year; however, the rate has grown to upwards of 3 percent in recent years in select parts of the region (Stubbs, 2007; Stephens, 2006)

- From 2005 to 2007 alone, more than 3.2 million new acres were planted to corn in PPR parts of Iowa, Minnesota, North Dakota, and South Dakota (Brooke and others, 2009)

- In the 10 years from 1997-2007, corn acreage in North Dakota increased by 300 percent (USDA, 2007 Agricultural Census).

While the overall number of farms has declined each decade, little change has occurred in the total number of acres devoted to crop production over the last half-century. Much of the conversion to agriculture took place early in the 20th century, and the relatively high conversion rates of native prairie have not translated into large increases in cropland. Agriculture in the PPR has seen its biggest changes in terms of crop mix. Strong grain and oil-seed commodity prices have resulted in record-high plantings of corn and soybeans. Forecasters seem to agree that this expansion will continue in the region with strong economic incentives and crop technologies aiding the movement.

Oil and gas development seems far from reaching a plateau. As noted, researchers have indicated the region could see another 20,000-30,000 wells drilled, more than 350 percent increase compared to current production levels. With increased production comes need for additional natural resource inputs and staging and transportation infrastructure, along with supplemental housing for field crews and their families.

Land conservation programs and organizations continue to focus on the PPR given its ecological significance and sensitivity. The CRP remains the dominant conservation program in the region, yet nearly 3 million acres of CRP in the PPR will be expiring by the end of 2013. With higher-thanaverage commodity prices and tightening fiscal budgets, the future of those acres is uncertain. However, all signs indicate the declining trend since 2007 will carry on into the future. The PPR will continue to be the cornerstone for the USFWS NWRS. Central to the wildlife refuge system mission, the PPR constitutes the most important breeding areas for migratory waterfowl and is likely to be the conservation focus area for investment of Duck Stamp dollars.

Recent statistics suggest land-use conversion to production is more than likely to continue in the region over the next few decades. The socioeconomic implications of such land-use change are at the center of discussion in the following two chapters. This chapter presented trends in land use to lay the foundation for relevance of such discussions. 


\title{
Chapter 2: The Prairie Pothole Region Economy and Economic Linkages to the Landscape
}

\author{
By William Gascoigne ${ }^{\mathrm{a}}$, Dana Hoag ${ }^{\mathrm{b}}$, Lynne Koontz ${ }^{\mathrm{a}}$, and Catherine Cullinane Thomas ${ }^{\mathrm{a}}$
}

The American rural economy over the past 35 years has experienced times of prosperity, disparity, and periods of stagnation (Deller and others, 2003). After strong growth in much of the 1970s, rural areas experienced a stall in employment and relatively weak growth in the 1980 s when compared to metropolitan areas. However, the recession of the early 1990s had a much softer impact on rural America than on metropolitan areas, at least in terms of job growth. Likewise, rural counties in the northern Great Plains maintained some of the lowest unemployment rates in the country following the recent recession of the late 2000s (USDA-ERS, 2011b).

The economy of the northern Great Plains is also said to be at a crossroad (Drabenstott, Freese and others, 2009). Once dominated by agriculture, this sector's contribution has been declining for decades (Johnson and Rathge, 2006). Farm employment as a percentage of the total workforce has been declining since the 1960s, yet this trend seems to have leveled out in the last five years (fig. 2-1). Higher-than-average commodity prices along with millions of acres enrolled in the Conservation Reserve Program (CRP) with enrollments set to expire in the next couple of years indicate a scenario of expanding agricultural production in the region. Aging babyboomers living in the Prairie Pothole Region (PPR) could lead to a significant turnover in land ownership, ultimately affecting the overall number of farms, average farm size, and land management practices. Local economies stand to be impacted if average farm size continues to increase and more families are removed from the rural landscape, especially if new landowners are from outside the region and retain their primary residence (Freese and others, 2009).

The oil and gas boom certainly has had both positive and negative impacts, bringing an infusion of jobs and reviving local businesses in the region, while also stressing municipal services and increasing crime levels (both criminal and environmental) (North Dakota Court System Annual Report, 2011). These land-use dynamics also stand to have an impact on wildlife species and corresponding recreation levels. Recreation and nature-based tourism continue to contribute significant dollars to the region and its local communities. In North Dakota alone, the tourism industry in 2010 contributed $\$ 4.62$ billion to the state economy, ranking third among

\footnotetext{
${ }^{a} U . S$. Geological Survey

${ }^{b}$ Department of Agricultural and Resource Economics, Colorado State University
}

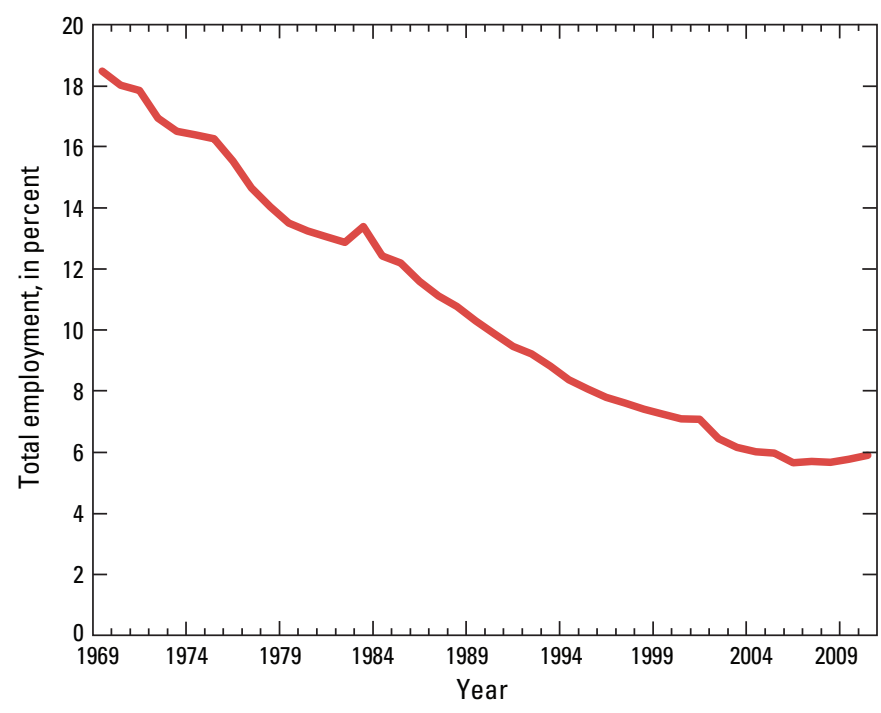

Figure 2-1. Farm employment by year as a percentage of total employment for the Prairie Pothole Region of the United States, 1969-2010. Modified from U.S. Department of Commerce Bureau of Economic Analysis (2010).

industries (North Dakota Tourism Annual Report, 2011). Outdoor, wildlife-based recreation is a major component of this larger industry, while also factoring into the more general perceived quality of life (Hodur and others, 2008).

Table $2-1$ provides a general breakdown of the PPR economy, identifying employment levels by sector. We observe that the major industries in the region are the retail trade, health care and social assistance, manufacturing and government and government enterprises (all greater than 8 percent employment). Farm employment in 2010 represented just over 6 percent of the total labor force in the PPR of the U.S.

The combination of retail trade, arts, entertainment, and recreation, and accommodation and food services - three sectors that reflect the tourism industry-make up over 18 percent of the total private labor force in the region. The North Dakota state tourism office estimated 1 in every 12 workers in 2006 owed their jobs to tourism.

While the economic influence of production activities such as farming and oil drilling are relatively straightforward, the economic ties to lands in a conserved state are much less distinct. This is largely due to the indirect nature of the economic benefits of such lands. For instance, lands enrolled 
Table 2-1. Total employment in the Prairie Pothole Region of the United States by sector, 2010. Modified from U.S. Department of Commerce Bureau of Economic Analysis (2010).

\begin{tabular}{|lrr|}
\hline \multicolumn{1}{|c}{ Industry } & $\mathbf{2 0 1 0}$ & $\begin{array}{r}\text { Percent } \\
\text { of total }\end{array}$ \\
\hline Total employment & $2,028,090$ & \\
\hline Wage and salary employment & $1,559,299$ & 76.9 \\
\hline Proprietors' employment & 468,791 & 23.1 \\
\hline Farm proprietors' employment & 100,932 & 5.0 \\
\hline Nonfarm proprietors' employment & 367,859 & 18.2 \\
\hline Farm employment & 127,371 & 6.3 \\
\hline Private (nonfarm) employment & $1,607,692$ & 79.3 \\
\hline Forestry, fishing, and related activities & 4,127 & 0.2 \\
\hline Mining & 8,640 & 0.4 \\
\hline Utilities & 3,995 & 0.2 \\
\hline Construction & 104,692 & 5.2 \\
\hline Manufacturing & 172,234 & 8.5 \\
\hline Wholesale trade & 79,606 & 3.9 \\
\hline Retail trade & 220,725 & 10.9 \\
\hline Transportation and warehousing & 47,036 & 2.3 \\
\hline Information & 27,831 & 1.4 \\
\hline Finance and insurance & 138,373 & 6.8 \\
\hline Real estate and rental and leasing & 57,092 & 2.8 \\
\hline Professional, scientific, and technical services & 66,505 & 3.3 \\
\hline Management of companies and enterprises & 12,023 & 0.6 \\
\hline Administrative and waste management services & 66,178 & 3.3 \\
\hline Educational services & 26,283 & 1.3 \\
\hline Health care and social assistance & 171,720 & 8.5 \\
\hline Arts, entertainment, and recreation & 31,268 & 1.5 \\
\hline Accommodation and food services & 114,395 & 5.6 \\
\hline Other services, except public administration & 99,974 & 4.9 \\
\hline Government and government enterprises & 293,027 & 14.5 \\
\hline Federal, civilian & 28,685 & 1.4 \\
\hline Military & 21,702 & 1.1 \\
\hline State and local & 242,604 & 12.0 \\
\hline & & \\
\hline
\end{tabular}

in the CRP have been found to have superior habitat suitability for waterfowl compared to cultivated lands (Reynolds and others, 2001; 2007). In turn, high waterfowl populations can attract new hunters and/or lead to more trips by existing hunters and to each group spending new money within an area. Similarly, conserved grasslands are associated with lower sedimentation rates than cultivated lands and have the potential to provide greater storm surge mitigation (Gleason and Euliss, 1998; Manale, 2000; Gleason and others, 2008). In this manner, conserved landscapes can reduce the financial burden on municipalities to treat drinking water and to minimize damages from flooding ${ }^{1}$. It is the goal of this chapter to further discuss aspects of the region's economy and to highlight these commonly indirect relationships to landscape conditions. This chapter includes a primary analysis of the economic contribution of hunting and wildlife viewing taking place in the PPR, the operational spending of the National Wildlife Refuge System (NWRS) in the region, the Partners for Fish and Wildlife (PFW) program in the PPR, and a case study highlight of a large-scale restoration activity which occurred recently within the PPR part of Minnesota.

\footnotetext{
${ }^{1}$ As was the case with New York City's water supply and their decision to invest in conservation in the Catskill Watershed (see Chichilnisky and Heal, 1998).
}

\section{The Role of the Farm Economy in the Prairie Pothole Region}

The rural economy largely has been synonymous with the farm economy. The agricultural sector has played an important economic role in the PPR since the beginning of the 20th century. In 2008, it was noted that this industry was more important to North and South Dakota's economy than to any other two states in the country, accounting for between 9-11 percent of the states' total gross domestic product (U.S. Dept. of Commerce Bureau of Economic Analysis, 2008). Cropland acreage has continued to increase in recent years given favorable grain and oil-seed crop prices. Cropland production in Iowa alone carried a market value of nearly \$20 billion in 2011, with cropland in North Dakota, South Dakota, and Minnesota equating to an additional \$26 billion (USDA-NASS, 2011). For decades, the agricultural sector was the dominant employer in the region. However, farm employment as a percentage of total jobs has been decreasing substantially over time. Figure $2-1$ reveals this employment trend from the late 1960 s to 2010 .

Accounting for nearly 20 percent of employment regionwide two generations ago, the farm industry is now responsible for directly employing only 6 percent of the entire labor force within the PPR. Reasons behind the decline are multifaceted, but many point to the technological advances in machinery and crop science that have reduced the need for hired farm hands (USDA-ERS, 1995; Johnson and Rathge, 2006; Irwin and others, 2010).

The Economic Research Service (ERS) of the USDA has defined farming-dependent counties as those which have either 15 percent or more of average annual labor and proprietors' earnings derived from farming, or 15 percent or more of employed residents working in farm occupations. Table 2-2 identifies the farming-dependent counties within the PPR portion of the four states considered in this report, based on employment statistics provided by the Bureau of Economic Analysis (BEA), as are used by ERS. Dotted lines identify the definition threshold, with counties above the threshold classified as farming-dependent and those below not so classified.

A majority of counties in North and South Dakota are considered to be farming-dependent by the USDA. Sheridan County and Kidder County in North Dakota have the two highest farm-employment percentages of any county in the PPR. Of 45 PPR counties in Minnesota, however, only 15 (or 33 percent) meet the national criteria for farm dependency. Likewise, only 8 of the 35 counties (or 23 percent) in the PPR region of Iowa meet the national criteria. As a state, Iowa has more people employed in farming and a greater overall production value, but county populations are much higher than in the Dakotas, diluting the employment dependence on the farm sector. When aggregated out to the PPR region of each state, the percentages of farm employment with respect to the total labor force are much smaller (see lower part of table 2-2). Farm employment constitutes 8.2 percent of total employment 
Table 2-2. Farm dependency of Prairie Pothole Region counties in the United States, 2010. Modified from U.S. Department of Commerce Bureau of Economic Analysis (2010). Dashed lines in table distinguish farming-dependent counties (above dashed line) with those that are not (below line).

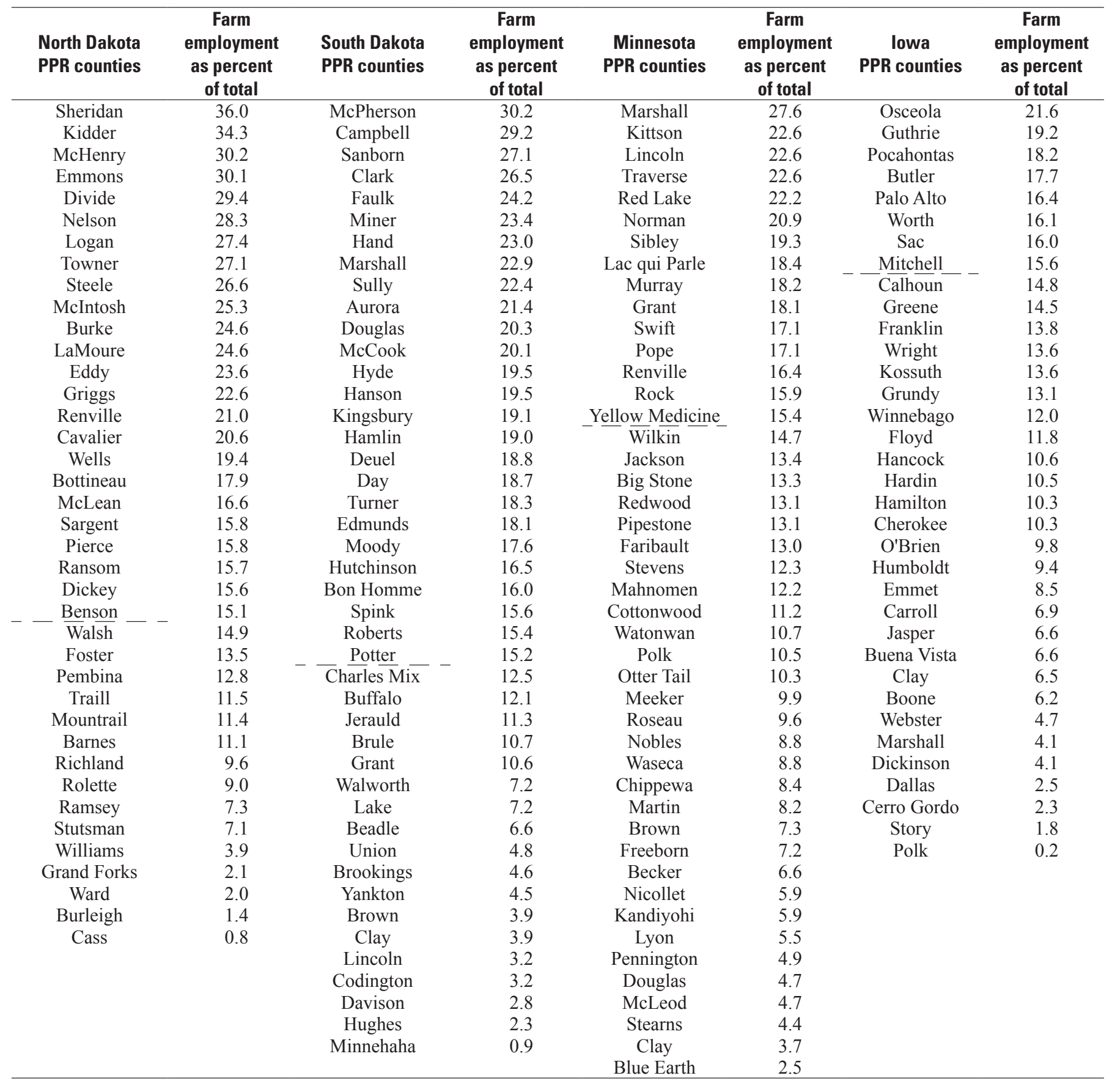


in the PPR part of Minnesota, while South Dakota, North Dakota, and Iowa sectors maintain percentages of only 5.8, 5.7, and 4.2 percent, respectively. These data show that farming has a much smaller influence on regional employment while still having some prominence at smaller, local scales.

Concurrently, off-farm income received by farm operators and their spouses has risen steadily over recent decades. The off-farm income share of total household income of U.S. farmers rose from about 50 percent in 1960 to more than 80 percent over the past 10 years (Fernandez-Cornejo, 2007). This statistic outlines the important relationship between the overall wellbeing of rural economies and the well-being of area farmers. The increasing average age of farmers in the region is another important trend. Retirement and mortality of the rural babyboom population over the next two decades could lead to large turnover in land ownership (Freese and others, 2009). There has been a substantial and increasing number of land purchases made for investment or recreational purposes by non-local buyers (Freese and others, 2009). Additional turnover also could lead to further farm consolidation, as has been observed over time. While the empirical literature modeling the impacts of increased farm size on the well-being of rural communities is mixed (see Deller and others 2003), candid conversations with local stakeholders in the region have indicated that farm consolidation has reduced the number of families out on the rural landscape. This likely has contributed to many rural communities having to consolidate school systems ([unidentified] Minnesota county commissioner, oral commun., June 2011).

While the market values of agricultural products are reaching all-time highs in the region, some local stakeholders have argued a large proportion of those dollars are not retained in the local communities (that is, are "leaked"), citing factors such as the increase in farm tenant leases to absentee landowners, decreasing nonproprietor farm employment, and increased reliance on specialized equipment manufactured outside of the region. However, there is no overall consensus in the literature regarding this trend, with the simple conclusion that the trend varies with the particular situation. It depends on factors noted above (for example, number of absentee landowners), the location and transportation infrastructure in the region, surrounding markets, the number of farm implement and supply dealers, the number of farm-related manufacturers, and a whole host of other variables including, more broadly, how the local region is defined. Smaller economies tend to have smaller economic ripple effects than larger economies (Deller and Williams, 2011). This is fairly intuitive given a small rural town is not likely to have all the supply dealers, transportation infrastructure, and processing facilities as compared to a larger defined region.

A more-refined approach to the multiplier theory touched on in the preceding paragraph might be found in the literature regarding farm structure. This was famously hypothesized by Walter Goldschmidt back in the 1940s, when he suggested larger, industrialized farming stood to have detrimental impacts on rural communities (Goldschmidt, 1947). Looking into the relationship between farm structure and economic well-being, Lobao (1990) found that, where industrialized farming takes hold, the potential for future economic wellbeing tends to decline. Lobao and Stofferahn (2007) examined over 50 studies looking into community effects of industrialized farming and found that nearly 60 percent of those studies found largely detrimental effects. Research performed by Marousek (1979) and the USDA (Harris and others, 2008) also found that as farms get larger, more complex, and more specialized, the more often they need to purchase inputs from outside the local area. The findings indicate that rural areas stand to experience more spending leakage as farm size increases.

Additionally, higher commodity prices do not necessarily translate into higher profits. That is to say, gross farm income is far different than net farm income (the part the farmer gets to keep). In the late 1920s when farming was much more labor-intensive and there were far fewer inputs to production, the ratio of gross farm income to net farm income was 1 dollar:49 cents, or for every dollar handled by the farmer, he/ she kept 49 cents (Levins, 2000). By 1960 the economics of agriculture changed profoundly as hybrid seeds were patented, mechanized equipment transformed efficiency of the farm, and chemical inputs provided greater yields, virtually skyrocketing the cost of inputs that ate into the bottom line of net farm income. Around the mid-century point, farmers were keeping just over a penny on the dollar. Since then, the ratio of gross farm income to net farm income has increased somewhat; over the last decade, farmers kept about 25 cents on every dollar earned (USDA-ERS, 2011a).

Agriculture in the PPR remains a prominent employer in the regional economy, and farm-household income levels are on the rise. While the micro-level, local impacts of agricultural revenues and spending are not definitive, the overall level of spending from agricultural enterprises seems to be up. As one county commissioner put it, "Things are pretty good. The local [automotive] dealer is sure selling a lot of pickup trucks." Beyond basic economics, agriculture has current and historic ties to the social and cultural makeup of the region. Such aspects can hold significant value to area residents, including those not involved in agriculture, and can add to the rural way of life that tends to attract visitors and new residents in various age classes.

\section{Economic Contributions of Perennial Habitat Lands}

In a national policy of directing land settlement, due consideration should be given to the needs, both national and local, for land to be devoted to crops, pasture, and forests *** Another important consideration is the economic value of wild life *** [the land's] value in the natural state as breeding places for fish, birds, and fur-bearing animals should be adequately considered. The recreational value of wild lands, as well as their direct economic value in the wild state, should not be overlooked. 
Clearly, the interests involved are too great to be left to chance *** Nor can such interests be left entirely to the individual States, for it frequently appears to be to the interest of a particular State to attract settlers from other States, with little reference to the bearing of such action on the national needs for the various uses of land or to whether the change is for the better from the standpoint of welfare and efficiency of the settlers.

- Lewis Gray and others, Agricultural Yearbook, 1924

At a time of competing interests on PPR land, it is important to understand and consider the economic value associated with all land uses. The above quotation by agricultural economist Lewis Gray ${ }^{2}$ makes note that this total value must include lands in a conserved or natural state, as the economic contributions of these lands can be significant. However, the economic contribution of perennial habitat lands is much less understood than that of production activities. In part, this is because the economic links back to the landscape often are indirect, and the services provided by the landscape typically are 'non-market' and 'public' in their nature; or in other words, services provided the ecosystems are not typically traded within a traditional market setting (for example, trucks sold at a dealership with an attached price tag), the benefits received by one person do not diminish the benefits received by others, and others cannot be effectively excluded from their benefits (for example, scenic view-sheds). While these characteristics create a need for economic valuation, they make it more difficult to assign values as there is no marketplace in which one can observe and reference relative prices. Nonetheless, nearly all of these services can be looked at from a humanistic viewpoint with underlying economic values. For instance, one can begin telling the story of the economic importance of natural grasslands when identifying the superior role they play in reducing runoff and contributing to mitigation of destructive flooding, or explaining the importance of groundwater recharge to a farmer who depends on an aquifer for irrigation water, or describing habitat benefits of conservation practices that result in more game birds for hunters to pursue, resulting in more people traveling to and spending money in an area. It is the link between ecological processes and human wellbeing that defines ecosystem services and provides context for valuing various land-use decisions (Daily and others, 1997; Millennium Ecosystem Assessment, 2003).

We estimate there to be around 9.3 million acres of perennial habitat classified as conserved or protected remaining in the PPR, a region that constitutes more than 91 million acres across the four U.S. states included in the analysis. The highest county proportions of these lands are near 30 percent, mostly located in northwestern Minnesota (on the outskirts

${ }^{2}$ Lewis Gray was an agricultural economist, long employed by the Bureau of Agricultural Economics in the U.S. Department of Agriculture, with a particular research interest in agricultural incomes and land use. He set the themes for land-utilization policies for the New Deal era through his seminal study in the 1923 USDA Agricultural Yearbook. of the actual PPR boundary), and include conserved acreage with standing timber (that is, non-prairie). Chapter 1 and figures $1-7,1-8$, and $1-9$ provide more detail on the amount of perennial habitat remaining the in PPR, as well as methodologies used to calculate totals.

Lands enrolled in the Conservation Reserve Program (CRP) represent 52 percent of the estimated conserved perennial habitat in the PPR. The CRP was developed around the premise that farmers would voluntarily enroll highly erodible cropland and other environmentally sensitive acreage and convert it to a certain vegetative cover in return for an annual rental payment. The program grew, in part, out of the realization that 11 percent of all cropland was accounting for 53 percent of soil losses on non-irrigated agricultural lands in the U.S.; that is to say, a relatively small amount of acreage was highly erodible (Muir, 2008). It was thought that enrollment of such acres would indirectly improve water quality and wildlife habitat as soil loss and sedimentation were minimized. Rental contracts for the CRP acreage ranged in length from 10-15 years, providing time for ecological recovery. Additionally, there was potential as well for the program to act indirectly as a price support for U.S. farmers by reducing the amount of land in production at a time when supply was greater than demand for major grain crops. The original target for the program was 44 million acres, which represented 11 percent of U.S. cropland in 1985. By 1993, over 35 million acres were enrolled, of which 8.7 million, or 25 percent of the nationwide total, were in the PPR states of North Dakota, South Dakota, Minnesota, and Iowa. The 2008 Farm Bill reduced the acreage cap for the CRP to the current 32 million acres, a 7 million-acre decrease from the previously allotted cap. However, at a time of record-high commodity prices when many CRP contracts are expiring, the current cap does not seem to be a limiting factor.

Impacts of the CRP on landowners, surrounding communities, agricultural markets, and the environment continue to be the focus of much research. The research findings regarding the impacts of the CRP can, by and large, be applied more generally to restored public grasslands (such as USFWS grasslands) and nongovernmental organization (NGO) lands (for example, The Nature Conservancy), given the similarity of restoration procedures, management practices, and the general structure of the planted grass. Research findings regarding the CRP should be (and sometimes are) recognized more broadly as impacts of restored habitat or idle grasslands.

As noted, the central idea of the CRP was to reduce soil erosion and accompanying nonpoint-source pollution. A study assessing various levels of ecosystems services on conservation program lands, cropland, and native prairie in the PPR estimated that restoration of cultivated cropland to perennial cover (under the Conservation Reserve Program and Wetland Reserve Program) reduced total potential soil loss by $1,940,254$ tons per year (tons $\cdot \mathrm{yr}^{-1}$ ) on 682,048 acres of upland habitat around wetlands (Gleason and others, 2008). For the same area, researchers estimated that nitrogen and phosphorous losses would be reduced by 5,622 tons $\cdot \mathrm{yr}^{-1}$ and 
75 tons $\cdot \mathrm{yr}^{-1}$, respectively. Assuming that reduction in annual losses remains static, Gleason and others (2008) estimated a cumulative soil-loss reduction of 23,314,050 tons and a cumulative reduction in nitrogen and phosphorus losses of 66,971 and 879 tons, respectively, since lands in the PPR had been enrolled in conservation programs.

Such potential reductions are significant and have important economic implications. Soil erosion and sediment flows not only impact the production capacity of the landscape for agriculture but can influence water flows for flood and drought mitigation, energy production, transportation efficiencies, recreation levels, and treatment costs to meet water-quality standards. Hansen and Ribaudo (2008) released a study and an accompanying database that estimate the per-ton benefit values for reduced soil erosion. Their study is a progression of work done by the USDA Economic Research Service (USDAERS) since the late 1980s and incorporates fourteen different categories of soil-conservation benefits estimated at the county level. Updating their database values to 2012 dollars (U.S. Department of Labor Bureau of Labor Statistics, 2012), soil-reduction benefits for counties within the defined PPR boundary average $\$ 3.59$ per ton. Multiplying that figure by the soil-reduction estimates derived by Gleason and others (2008) produces an annual soil-reduction benefit of around $\$ 6.9$ million for CRP and WRP acreage in the PPR. While this transfer of values may be generalized and not detailed enough for specific policy analysis, it does provide context for discussion and identifies the relative magnitude of such values.

Restored lands have provided high levels of other ecosystem services as well. Lands that have been planted back to long-term vegetative cover have been documented to sequester higher levels of atmospheric carbon when compared to cultivated cropland. Research suggests that wetlands and grasslands in the PPR historically were sinks for atmospheric carbon, but cultivation associated with agriculture has shifted their function to net sources of atmospheric carbon (Follett and others, 2001; EPA, 2003; Euliss and others, 2006). Gleason and others (2008) measured the average difference in soil organic carbon (SOC) between wetland catchments that had been cultivated for cropland and those that remained in native vegetation, as a measure of CRP potential to sequester atmospheric carbon. Using published carbon sequestration rates for restored grasslands, these scientists (Gleason and others, 2008) indicate PPR wetland catchments enrolled in the CRP and WRP have the potential to sequester 244,960 tons $\cdot \mathrm{yr}^{-1}$, for an estimated total of 2,989,411 tons since the lands were restored. Furthermore, the authors determined that an additional 788,034 tons of vegetation organic carbon (VOC) could be sequestered in the plant biomass in wetland catchment areas. In addition to sequestering atmospheric carbon, native and restored grassland habitats have been found to reduce emissions of other greenhouse gases, such as nitrous oxide $\left(\mathrm{N}_{2} \mathrm{O}\right)$ and methane $\left(\mathrm{CH}_{4}\right)$ (Mosier and others, 1991; Chan and Parkin, 2001; Merbach and others, 2002).
Greenhouse gases have an obvious role in the global climate-change discussion, involving a wide array of potential impacts with regards to emission scenarios. Markets established for carbon-credit trading are ambiguous and prices seem to be influenced heavily by political/legislative insinuation, rather than by actual societal values. Given uncertainty regarding future impacts, estimated values based on direct costs to society range across the board. The U.S. government recently assembled a working group of experts on this particular valuation, which ultimately proposed a central value of $\$ 21$ ton of $\mathrm{CO}_{2}$ (U.S Government Interagency Working Group on Social Cost of Carbon, 2010). Societal values provided by carbon sequestration and conserved grasslands within the PPR could garner significant payments for these credits as future impacts unfold and markets develop.

Probably the most published ecosystem service and associated benefit of perennial habitat lands is the habitat suitability for game and non-game wildlife species, and the subsequent increase in recreation participation and enjoyment levels. The CRP alone has been extremely influential on particular wildlife population levels (see Allen and Vandever (2012) for a comprehensive review). It is not of great surprise that hunter activity corresponds to wildlife population levels. Simply put, hunters tend to hunt more when there are more animals to hunt, and vice versa. Not only do species population levels directly influence the amount of recreation available (through the number of hunting permits issued by state fish and game offices), but also indirectly as they factor into the quality of the hunting experience. Reduced wildlife populations can result either in fewer hunters wanting or able to hunt (a quantity effect) and/or the same number of hunters hunting less often (a quality effect) as success rates presumably are lowered. The same is true with wildlife viewing. Both quantity and quality effects from decreasing population levels likely will result in less money being spent on various goods and services associated with that activity. Sullivan and others (2004) estimated that if CRP contracts ended (in 2001) 51 percent of CRP lands would return to crop production, and spending on outdoor recreation would decrease by as much as $\$ 300$ million per year in rural areas. Similarly, Bangsund and others (2004) focused on the CRP's contribution to hunting activity in rural areas of North Dakota and estimated that the CRP was responsible for $\$ 12.8$ million (2004 dollars) in annual recreational revenues in just sixteen rural counties.

Of game species impacted, restored grassland and wetland efforts have had a tremendous beneficial impact on migratory waterfowl, ring-necked pheasants (Phasianus colchicus), and white-tailed deer (Odocoileus virginianus). The PPR is often referred to as the "Duck Factory," as the region historically has produced 50-80 percent of North America's waterfowl, while accounting only for 10 percent of the available breeding habitat (Batt and others, 1989; Young, 2008). Permanent cover established through restoration efforts provides attractive and more secure nesting habitat for upland-nesting ducks (Kantrud, 1993). Nest success has been 
determined to be the most important variable in maintaining waterfowl population levels (Hoekman and others, 2002). Declines in duck nesting success in the PPR generally have coincided with the conversion of grasslands to cropland in the region, with researchers finding duck nesting success to be related negatively to the proportion of the landscape annually cultivated (Greenwood and others, 1995; Reynolds and others, 2006). Reynolds and others (2001) studied the impact of CRP lands in the PPR on duck production and found that CRP cover was the preferred nesting habitat for five of the major upland-nesting species. Reynolds and others (2007) used their findings and refined modeling techniques to estimate that the CRP was responsible for 1.9 million additional ducks produced annually in the PPR during the period 1992-2004. These results bring the total incremental increase in waterfowl production attributed to the CRP to 25.7 million in that 12-year period.

The ring-necked pheasant, an upland game-bird species, also has benefited from perennial habitat established through cropland retirement programs and restoration efforts (Erickson and Wiebe, 1973; Eggebo and others, 2002; Nielson and others, 2006). The precursor to the CRP - the Soil Bank - provided improved habitat throughout the Midwest starting in the mid-1950s. Referencing the response in South Dakota, Dahlgren and Linder (1967) noted, "Thevalue of good habitat to the pheasant population can be seen by comparing the population of the mid-'50s, four to six million birds, with that at the height of the Soil Bank, eight to eleven million. Good cover nearly doubled the pheasant numbers." A repeated survey of Minnesota landowners with CRP lands in 1997 and 2006 showed 94 percent (1997) to 98 percent (2006) believed that the CRP improved pheasant habitat in the vicinity of their farm (Mitchell and Kimmel, 2009). The same question was asked to landowners without CRP lands, which resulted in a large majority (70\% in 1997 and 85\% in 2006) agreeing with the assertion that CRP had improved pheasant populations. A three-year study counting and monitoring pheasant crowing in eastern South Dakota (Eggebo and others, 2002) revealed more crowing pheasants on CRP fields than on any other cover type in the study area. That study confirmed extensive utilization of CRP fields by the upland game bird.

It is widely asserted that the two most important variables to pheasant populations are the amount of available habitat and the severity of weather conditions (that is, snow in winter and rain in the spring). While characteristic severe weather conditions limit the region's overall pheasant population, perennial habitat cover can increase the carrying capacity (Leier, 2009). In this respect, pheasants can recover more quickly from harsh winters. Lier (2009) provided these discrete statistics:

North Dakota had several relatively mild winters in the early 1980s. Without CRP or any other longterm land-idling program, the pheasant harvest increased from about 60,000 in 1979 , following two severe winters, to 141,000 in 1984 . With CRP, hunters bagged about 136,000 roosters (male pheasants) in 1997 following the worst winter in three decades. Since then, annual harvest has increased gradually to more than a half-million birds. In summary, without CRP $-60,000$ to 141,000 in five years. With CRP $-136,000$ to 517,000 in five years.

From 2007 to 2010, Iowa had the largest percentage decrease in CRP acreage of the four PPR states in the analysis, at almost 29 percent (table 1-2). That decrease has been compounded with loss of acres in hay and small-grains (that is, acres that provide some degree of habitat for pheasants). The state has seen its pheasant population decrease, on average, since the late 1960s alongside the decrease in these particular habitat acres (fig. 2-2).

Figure 2-2 shows the increase in acreage devoted to corn and soybeans, which largely mirrors the decrease in conservation program acres and acres in hay and small grains. The large dips in the pheasant population tend to correspond with severe weather events. As noted, the role of good perennial habitat is to help guard against such events and to provide quality nesting cover to allow populations to recover. Iowa has seen a steady decrease in pheasant numbers since 2003 . The pheasant count in 2010 was the lowest count in the state's history since it started recording population levels.

Upland game hunting in Iowa has decreased with the decline of pheasant populations (fig. 2-3). Once involving more than 300,000 hunters, the upland hunting level in Iowa (including residents and nonresidents) in 2010 was near 60,000 . The number of licensed pheasant hunters observed in 2010 was the lowest in the state's history since recordings began in the early 1960s. A simple regression analysis of Iowa hunting levels (resident and nonresident hunters) as a function o pheasant population levels shows the two variables to be highly correlated in a positive way $\left(p=0.01 ; R^{2}=0.64\right)$. That is, Iowa pheasant hunting activity is largely determined by pheasant populations, and hunting levels mirror changes in population, rising when pheasants increase, and decreasing when the birds decline

The highest hunting activity levels for pheasants in Iowa took place during the 1973 season. Since that time, Iowa has lost nearly 248,000 pheasant hunters; an 80 percent decline. That loss certainly has economic significance. Using the spending profiles from Bangsund and Leistritz's (2003) survey of upland game hunters, this reduction in hunting activity translates into the loss of $\$ 227.8$ million annual direct expenditures (2011 dollars) ${ }^{3}$. When run through an economic input-output model ${ }^{4}$ that tracks linkages between sectors and resulting ripple effects of spending, it is estimated that this loss in spending activity equates to nearly 4,000 jobs, $\$ 102$ million in labor income, and around $\$ 170$ million in value added when considering both direct and indirect effects. That is to

\footnotetext{
${ }^{3}$ In this calculation we assumed the historic average split of resident and nonresident hunters ( 75 percent: 25 percent), calculated from hunter data provided by Iowa DNR.
}

${ }^{4}$ IMPLAN (MIG, Inc.), V. 3, 2009 county-level data. 


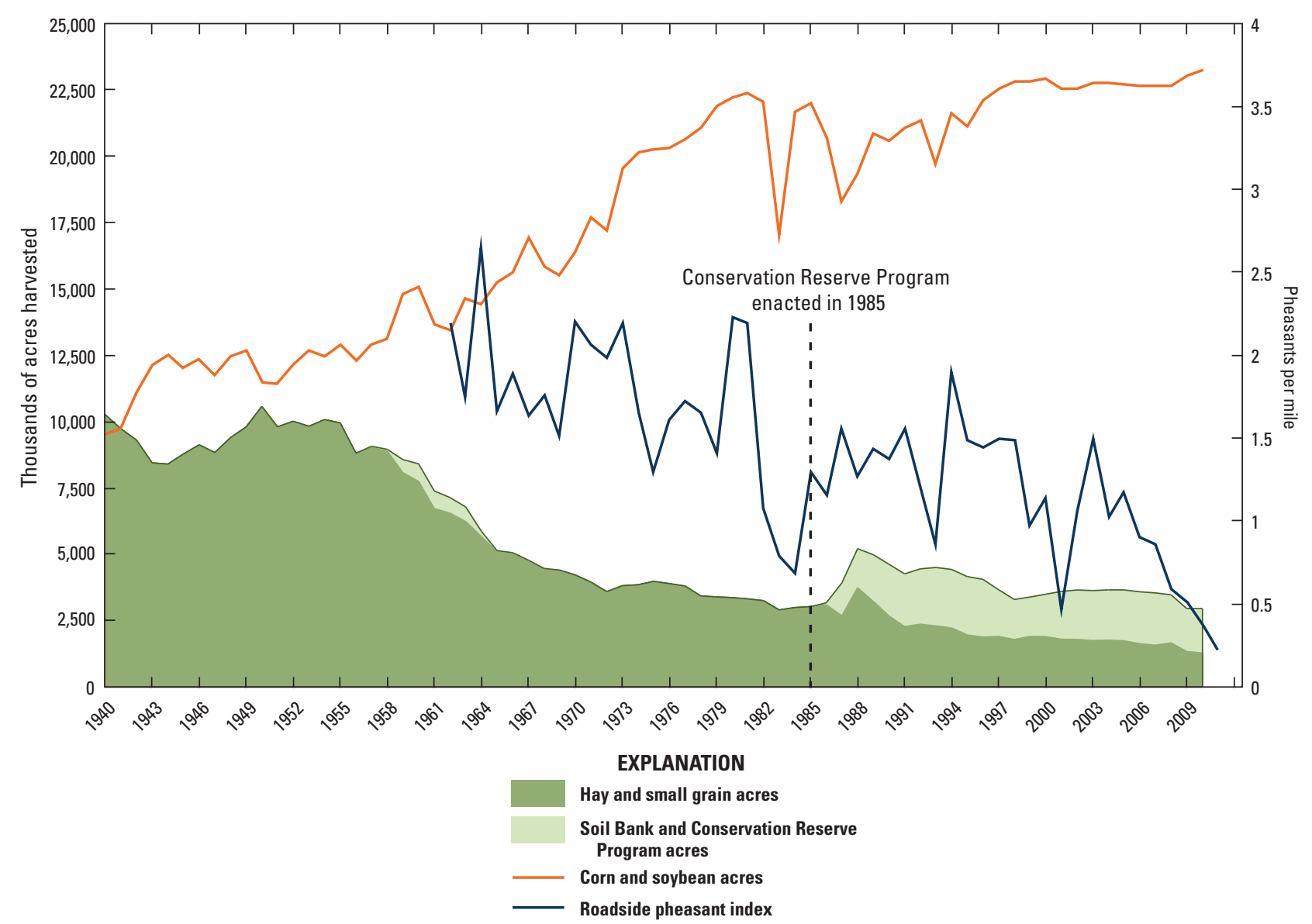

Figure 2-2. lowa conservation program acres, corn/soybean acres, and pheasant-count figures, 1940-2011. Modified from lowa Department of Natural Resources (2010). Conservation program acreages are stacked above hay and small-grain acreages.

say, if Iowa were able to attract an additional 248,000 pheasant hunters and reach historic levels, it would create that estimated level of economic activity. This modeling technique does not account for any structural changes (that is, new businesses emerging) from such an expenditure shock, which could result in even larger economic impacts. Alternatively, these job and income effects would take time to formulate and could be smaller if economic sectors weren't in place to foster the job growth from such a spending increase. This modeling technique does not account for substitution effects from other recreation activities nor between businesses within the region which would then be indicative of a transfer of payment and not new additional economic activity. Furthermore, it is not posited here that the loss of habitat is the sole reason for the decline. The significant correlation back to habitat conditions, however, cannot be denied and reflects previous research findings that show a positive relationship between conservation program acres and healthy pheasant populations (Erickson and Wiebe, 1973; Riley, 1995).

Similar to pheasants, deer populations are sensitive to winter conditions and rely on suitable habitat in which to shelter during harsh conditions. Greg Link, a conservation and communications division chief for the North Dakota Game and Fish Department notes, "We needed good winters to get the populations we had, but with tough winters, you really need that good cover. As you reduce the habitat base, you just have less ability to rebound. It takes a long time" (Dokken, 2011). During the mid-2000s, with over 3 million acres enrolled in the CRP and relatively mild winters, deer populations in North Dakota reached record highs. Harsher winters in recent years and higher doe-harvest management objectives, however, compounded with loss of more than 300,000 acres of CRP (and other perennial habitat) in the state since 2007, have contributed to large reductions in deer herds in various parts of North Dakota (Dokken, 2011; Grovenburg and others 2012a, 2012b; W. Jensen, North Dakota Game and Fish Department, 2012, oral commun.). Grovenburg and others (2012b) found restored grasslands in South Dakota to be utilized highly by white-tailed deer fawns, and those acres reduced the need for deer to migrate, during which they become more susceptible to predators. Bill Jensen, a big-game biologist for the North Dakota Game and Fish department, noted that these patterns also have been observed in his state. Aerial surveys during harsh winters have shown the extensive use of CRP lands and other perennial habitat, such as upland zones of wetland catchments (W. Jensen, North Dakota Game and Fish Department, 2012, oral commun.). 


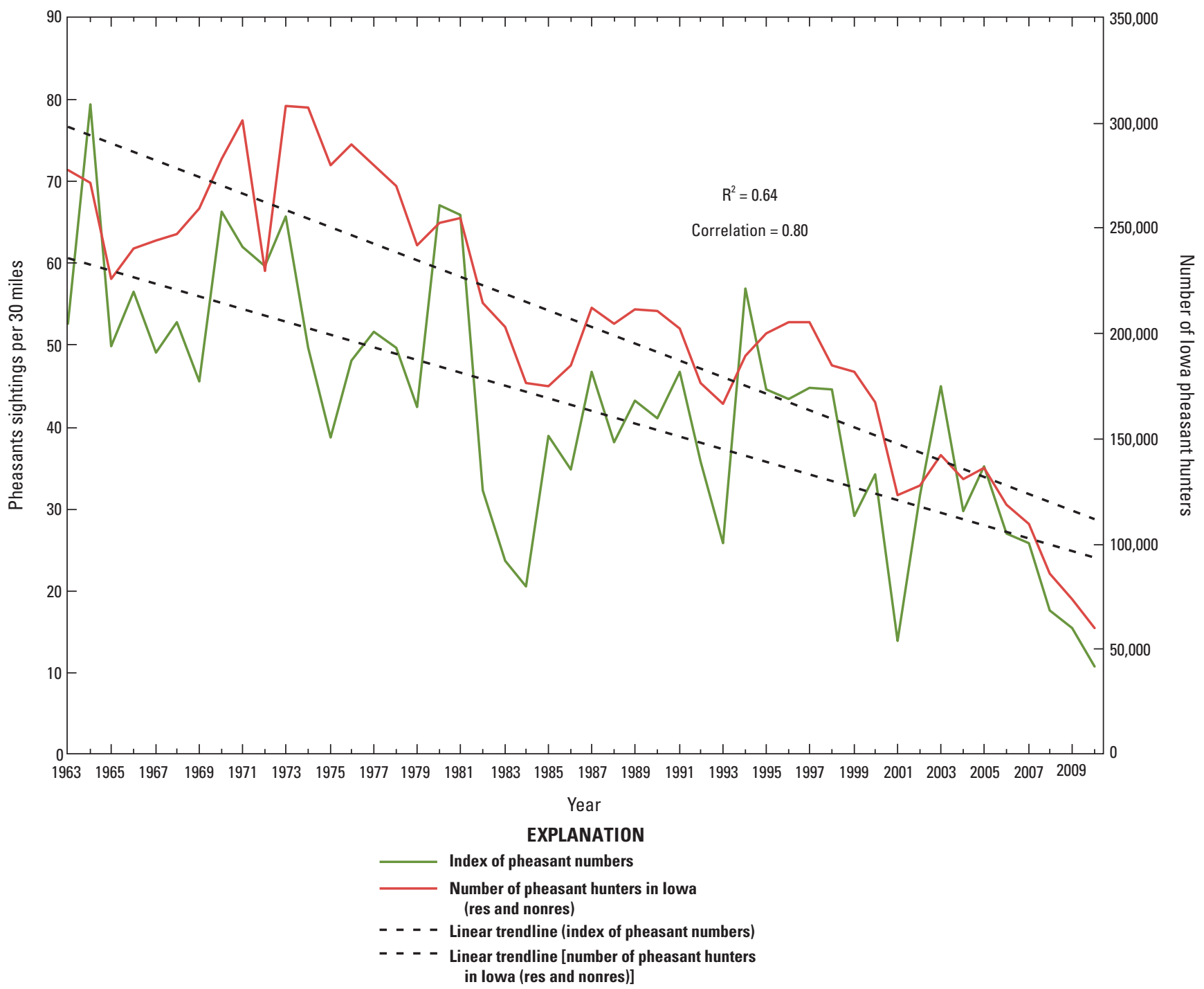

Figure 2-3. Correlation between pheasant populations and number of upland game hunters in lowa, 1963-2010. Data modified from lowa Department of Natural Resources (2010). [Abbreviations: res, residents; nonres, nonresidents; \#, number]

While deer numbers in any one year are affected by a suite of factors, wildlife biologists in the PPR have observed long-term trends suggesting the decreasing amount of perennial grasslands and alterations to wetland habitats through tile drainage have had major effects on overall deer population, as well as on migration patterns of mule deer (Odocoileus hemionus) off the prairie landscape west to the Badlands (W. Jensen, North Dakota Game and Fish Department, 2012, oral commun.). Determining hunting-license allotments also is multifaceted but ultimately boils down to meeting species population goals. It is projected that in 2012, North Dakota will likely offer fewer than 100,000 deer licenses. That would be the lowest number of licenses issued in the state in over a decade.

The number of acres enrolled in the CRP also has large impacts on the amount of land available to hunters, given the ties CRP acres have to hunter-access programs in the region. For instance, more than a third of the million acres in North Dakota's hunter-access program-PLOTS - is also enrolled in the CRP. Similarly, South Dakota has over 1.27 million total acres in the state's Walk-In Area (WIA) hunter-access program, which specifically targets lands enrolled in the CRP. A CRP contract is a mandatory requirement for enrollment in Minnesota's private lands hunter-access program. These programs provide landowners a financial incentive to keep continuous tracts of land in wildlife habitat and to allow public hunting access to their private lands. The revenues are in addition to existing CRP/WRP/CREP payments. Those programs have been very successful within the region given the strong majority of lands are in private ownership. It was documented in 2009 that 37 percent of resident hunters and 29 percent of nonresident hunters used the South Dakota WIA access program (South Dakota Game, Fish and Parks, 2011). If perennial habitat acres continue to decrease, that likely would lead not only to reductions in wildlife populations but also could translate into significant losses of land available to residents and nonresidents on which to hunt. Hunting activity could shift elsewhere or disappear altogether, along with the dollars spent. 
While agriculture and other production land uses remain important economic engines, the literature cited and analyses documented in this chapter demonstrate that conservation lands also retain economic value of significant proportions. Recreation values alone have been documented to offset a substantial portion of agricultural losses from retiring cropland (Bangsund and others, 2004) and are vital to the multibilliondollar tourism industry in the region. Alterations to ecosystem functions and to the services provided can have economic significance and should be considered when making related policy decisions.

\section{Economic Contribution of Hunting and Wildlife Viewing in the Prairie Pothole Region}

Consumptive (for example, hunting) and nonconsumptive (such as wildlife viewing) recreationists tend to spend significant dollars on travel, lodging, food and drink, and necessary equipment. Additionally, a large majority of those dollars (in the case of the PPR) are spent in rural areas (Bangsund and Leistritz, 2003). Once recreationists arrive in an area, they often spend money on additional, non-recreationrelated items. It is not uncommon to see local motels in the small rural towns with "no vacancy" signs come late summer and into fall. The PPR portion of South Dakota alone attracted an estimated 79,600 people from out of state to hunt pheasants in 2010 (South Dakota Game, Fish and Parks, 2010). Some local municipalities are well aware of this economic surge and have started to develop festivals and cultural events appealing to the recreational community both during and outside hunting seasons. Examples include Goose Fest in Kenmore, North Dakota; Duck Fest in Bowdon, North Dakota; Pheasant Fest in Plankinton, South Dakota; Festival of Birds in Detroit Lakes, Minnesota; and the Annual Potholes and Prairie Birding Festival in Carrington, North Dakota, among many others. Hodur and others (2004) surveyed attendees of the 2004 Potholes and Prairie Birding Festival and documented that participants spent on average $\$ 280$ (inflated to 2011 dollars) during the course of the four-day event. Data collected at that festival by Hodur and others indicate that if a town in North Dakota were able to attract 1,000 nature tourists, the total (including direct spending effects and secondary ripple effects) expenditure impact within the state would equate to more than $\$ 535,000$ in sales and be expected to support about six jobs within the area economy. ${ }^{5}$

Estimates have been produced for the economic contribution of hunting, fishing, and wildlife viewing for the four PPR states considered for this report; they have been done, however, at the individual state level (Leitch and Baltezore, 1993; Bangsund and Leistritz, 2003; Fry and others, 2011). Additionally, some of the national efforts that estimate state-level impacts are limited in sample sizes and expenditure categories,

\footnotetext{
${ }^{5}$ These spending impacts are based on visitation and spending patterns of folks attending the 2004 Potholes and Prairie Bird Festival (Hodur and others, 2004).
}

and studies lump hunters who may have hunted with different methods of take (for example, rifle versus archery) and/or sought different species. All such variations can affect modeling accuracy. Our analysis attempts to focus on the regional economy of the PPR and the particular land-use dynamics and activity patterns taking place within that economy. Furthermore, the analysis aims to identify the specific contributions of activity levels taking place separately on public and private lands. We do so by employing expenditure profiles from Bangsund and Leistritz's (2003) survey of North Dakota hunters ${ }^{6}$. Those expenditure profiles were chosen given their much larger sample size and breakdown for individual hunting license types (rifle, archery, muzzleloader); both sample size and license breakdown greatly increase the accuracy of the estimation. While the Bangsund and Leistritz (2003) survey was distributed specifically to license holders who hunted in North Dakota (that is, residents and nonresidents), the moderate assumption is made that those who hunted in North Dakota resemble those who are hunting (and spending dollars) in South Dakota, western Minnesota, and northern Iowa.

Spending profiles regarding average daily expenditures for the three primary types of hunting - deer, waterfowl, and upland game - were matched with estimates of the number of hunting days, and also separated by species, method of take (in reference to deer hunting only), and residency (resident or nonresident). ${ }^{7}$ Hunting activity levels typically are measured at the state level, given accumulated licensing figures and variation in travel patterns. Some states have begun to track hunter distribution at smaller scales (that is, county-level and/or specified hunting units), given new requirements for harvest registration and license sales specific to hunting units. Estimates for hunting days were generated from a myriad of sources in efforts to use the most applicable, recent, and reliable data available. Those data sources are organized by state and displayed in Appendix C. Estimates were refined to the county level before aggregating to the PPR level of the four states.

Data regarding nonconsumptive wildlife viewing are much more limited. In particular, participation levels are harder to monitor given that no license is required for most nonconsumptive activities. The National Wildlife Refuge System (NWRS), under the authority of the USFWS, has a strong presence in the PPR and provides great opportunities for wildlife viewing. The USFWS, through various methods, produces annual estimates of visitation to NWRs and additional sites within Wetland Management Districts in the Refuge Annual Performance Plan (RAPP). We rely on the

\footnotetext{
${ }^{6}$ Per-day spending estimates are displayed in Appendix C. For complete breakdown of spending patterns, see Bangsund and Leistritz (2003).

${ }^{7}$ State-level spending profiles were refined to the regional level by consulting with state wildlife agency representatives familiar with hunting activity and spending patterns. After consultation, we did not alter spending amounts in PPR counties in North Dakota, South Dakota, and Iowa. Minnesota estimates were refined given the presence of the Twin Cities and the likelihood that some spending took place outside of the PPR in those metropolitan areas. Appendix C provides more detail on that refinement.
} 
RAPP dataset to estimate conservatively the nonconsumptive visitation levels in the PPR. Visitation figures for local and non-local participants are matched with spending profiles for nonconsumptive recreationists provided by the Economics Division in the USFWS and produced for the fiscal year (FY) 2011 Department of Interior Economic Contribution Report.

Once recreation levels and expenditure data are acquired, those data are uploaded into a regional input-output model to account for all economic influence. Given the interdependencies of the economy, spending in one sector can have impacts on many others, ultimately equating to direct, indirect, and induced effects. Direct effects include the jobs, wages, and economic activity created by upfront spending. For instance, when recreationists directly spend money at restaurants, the owners might have to increase their staffing to keep up with the higher customer level. The restaurant will also have to order additional supplies from their suppliers, who then might have to increase their ordering and inventory as well (that is, indirect effects). Induced effects are brought about when additional wages paid to employees are spent within the local community. Indirect and induced effects are known as secondary effects, accounting for the multiplier or ripple effect on initial spending. The sums of the direct and secondary effects describe the total economic contribution of associated spending.

Expenditures were analyzed using the IMPLAN (Impact analysis for PLANing) modeling software ${ }^{8}$ (MIG Inc., 2009). IMPLAN is a computerized database and modeling system that provides regional input-output analysis of economic activity in terms of industrial groups and various sectors. The model explains the flow of goods and dollars from commodity suppliers, to manufacturers, to intermediaries, and finally to the end user. Regional economic effects from the modeling effort are reported for the following categories:

- Employment represents the number of jobs generated in the region. IMPLAN estimates for employment accommodate full-time, part-time, and temporary jobs.

- Labor income includes employee wages and salaries, including income of sole proprietors and payroll benefits.

- Value added measures contribution to gross domestic product. Value added is equal to the difference between the amount for which an industry sells a product and the production cost of the product, and is thus net of intermediate sales.

Model results for the three primary hunting activities and nonconsumptive wildlife viewing are presented in table 2-3.

The total (that is, direct, indirect, and induced) economic contribution of hunting is divided into variable and fixed costs. Variable costs refer to nondurable items that were purchased by hunters over the course of the season. These are items that cannot be used over and over, such as ammunition, guiding fees, and lodging. Fixed costs refer to durable items that have

${ }^{8}$ IMPLAN version 3 software was used with 2009 county-level data. the potential to be used over the course of many seasons, and even in other activities. Examples include binoculars, clothing, and decoys. The durability of such items makes it more difficult to model the annual contribution of such purchases; they do represent, however, a significant proportion of hunter expenditures. Additionally, by averaging over a representative sample, an approximate overall level of annual purchases for durable goods can be estimated [as was the case with the spending profiles in Bangsund and Leistritz (2003)]. When considering all expenditures and both direct and secondary effects, it is estimated that hunting activity in the PPR is responsible for annually contributing just over 8,800 jobs, $\$ 245$ million in labor income, and \$408 million in value added to the regional economy. Nonconsumptive recreation taking place on NWRS lands was estimated to contribute an additional 550 jobs, $\$ 15.6$ million in labor income, and \$26 million in the value-added category.

Hunting on public lands - an area comprising less than 5 percent of the lands in the PPR - contributed 25 percent of the total number of jobs, labor income, and value added from hunting activities. This figure indicates that public lands in the PPR are an important source of hunting opportunity, while representing only a small proportion of the total land area. With CRP acres and private land-access program acres likely to decline in the next few years, the potential exists for hunters to depend even more on public lands for their recreation.

The economic values estimated in this section of this report were modeled very conservatively. Efforts were taken to avoid overinflating associated spending and to use the most reliable, region-specific data. Additionally, estimates for the economic contribution of hunting do not take into account all hunting activity taking place in the region. For instance, due to data limitations, estimates do not include pronghorn hunting (North and South Dakota); big game hunting for elk, moose, bear, or mountain lion; spring or fall turkey hunting; predator hunting for coyotes and such; nor do they account for other small-game hunting activities besides upland game and waterfowl. Those additional hunting activities certainly add to the overall spending taking place and create additional employment and revenue not included in table 2-3. Bangsund and Leistritz's (2003) study of hunting in North Dakota estimated that turkey hunters alone were spending around \$2.3 million (2011 dollars) in the state each year.

This economic contribution analysis also does not account for other fish- and wildlife-related recreational opportunities that are influenced by habitat conditions. Trapping for furbearers continues to be a popular activity that generates considerable spending in the region (Leitch and others, 1993; Hodur and others, 2002). Likewise, this analysis does not model the contribution of resident and nonresident angling in the PPR, estimated to be even larger than hunting contributions. In North Dakota alone, angling is estimated to support around 8,000 full-time-equivalent employees (Bangsund and Leistritz, 2003). Changing land use surely can have impacts on fish populations and the overall quality of an angler's experience, ultimately affecting levels of spending in rural areas. To 
Table 2-3. Total (direct and secondary) economic contribution of hunting and wildlife viewing to the United States Prairie Pothole Region economy.

\begin{tabular}{lccc}
\hline $\begin{array}{c}\text { Total (direct and secondary) economic contribution } \\
\text { to the PPR regional economy }\end{array}$ & $\begin{array}{c}\text { Employment } \\
\text { (jobs) }\end{array}$ & $\begin{array}{c}\text { Labor income } \\
\text { (millions of dollars) }\end{array}$ & $\begin{array}{c}\text { Value added } \\
\text { (millions of dollars) }\end{array}$ \\
\hline & Hunting & 150.2 & 246.0 \\
\hline Variable costs & 5,000 & 95.0 & 162.7 \\
Fixed costs & 3,800 & 245.3 & 408.7 \\
Total (all activity on public and private lands) & 8,800 & 60.5 & 100.9 \\
Public lands-specific (of total) & 2,200 & 15.6 \\
\hline \multicolumn{3}{l}{ Nonconsumptive wildlife viewing } \\
\hline U.S. Fish and Wildlife Service lands only & 550 & 26.0 \\
\hline
\end{tabular}

reiterate, the nonconsumptive estimates in table $2-3$ account for activity only on NWRS lands across the four PPR states. It does not include nonconsumptive recreation taking place elsewhere, such as on state and county park lands, other federal lands, and private acreage. Those negated impacts (due to data limitations) could be substantial and certainly are influenced by changes in land use and resource availability. In summary, our estimates account only for a percentage of the recreation taking place in the PPR that is tied to habitat conditions. It was our intention to show the relative economic significance provided by the population's recreational activities within the region.

\section{Economic Contribution of the U.S. Fish and Wildlife Service National Wildlife Refuge System Operations and the Partners for Fish and Wildlife Program in the Prairie Pothole Region}

The restoration, maintenance, and oversight of conservation lands can require extensive resources. This includes the hiring of personnel to implement and manage the project, the hiring of individuals to do the actual restoration work, and the funds to purchase the material necessary to complete the job. The U.S. Fish and Wildlife Service (USFWS) is an agency heavily involved in conservation in the PPR. Through their National Wildlife Refuge System (NWRS), the USFWS owns and manages 72 NWRs as well as an extensive suite of Waterfowl Production Areas (WPAs) within the PPR. These are public lands managed for wildlife species, while also incorporating visitation and commonly many other uses such as hunting. Additionally, the USFWS is involved in restoration efforts on private lands through their Partners for Fish and Wildlife (PFW) program. The PFW program was designed to complement many of the traditional USFWS easement programs by offering restoration and enhancement agreements for shorter time periods. The program provides direct financial and technical assistance for restoration activities, with agreement from the private landowner that the land won't be converted for a period of time. These efforts look to restore wetlands and other fragile lands that typically are marginal in production value but high in ecological value.
Using fiscal-year 2011 funding data, the economic contribution of the NWRS operational expenditures and the PFW program to the PPR economy was modeled. USFWS staff members were consulted regarding nonsalary expenditures to determine how those dollars were being spent. For example, it was determined what percentage of nonsalary expenditures went specifically to leasing heavy machinery from area dealers, buying seed from local vendors, and arranging waterdelivery systems from nearby retailers. Itemized receipts from a sampling of restoration projects in the region were examined to estimate similar percentages for dollars spent on restoration through the PFW program. The various expenditures were matched with representative industry sectors and modeled in IMPLAN. Labor and wage data for the model were handled to produce anticipated conservative estimates. The estimates for the NWRS operations include refuge revenue-sharing payments made to PPR counties in lieu of property taxes. The model results are displayed in table 2-4.

The operational spending of the NWRS is estimated to support 720 full-time jobs in the region, in addition to providing \$32 million in labor income and nearly \$39 million in value added to the economy. Again, this does not account for the economic activity generated by all the visitors to refuge lands.

Table 2-4. Total (direct and secondary) economic contributions of U.S. Fish and Wildlife Service National Wildlife Refuge System operations and the Partners for Fish and Wildlife Program.

\begin{tabular}{lccc}
\hline \multicolumn{1}{c}{ Impact type } & Employment & $\begin{array}{c}\text { Labor income } \\
\text { (millions } \\
\text { of dollars) }\end{array}$ & $\begin{array}{c}\text { Value added } \\
\text { (millions } \\
\text { of dollars) }\end{array}$ \\
\hline \multicolumn{4}{c}{ National Wildlife Refuge System Operations* } \\
\hline Direct effect & 525 & 25.8 & 26.5 \\
Indirect effect & 20 & 0.9 & 1.4 \\
Induced effect & 175 & 6.0 & 10.9 \\
Total effect & 720 & 32.7 & 38.9 \\
\hline \multicolumn{4}{c}{ Partners for Fish and Wildlife Program } \\
\hline Direct effect & 100 & 3.2 & 3.3 \\
Indirect effect & 20 & 0.4 & 0.5 \\
Induced effect & 40 & 2.2 & 4.0 \\
Total effect & 160 & 5.8 & 7.8 \\
\hline
\end{tabular}

*Note: Table includes only operational expenditures and not the impacts generated by visitors or other activities on refuge lands. 


\section{Case Study Highlight: Glacial Ridge Restoration and Subsequent National Wildlife Refuge, Polk County, Minnesota; Economic Impacts}

The Agassiz Beach Ridges landscape is located in the Red River of the North watershed of northwestern Minnesota and falls within the larger Prairie Pothole Region (PPR) of the United States. The prairie of the Great Plains has been identified as North America's most endangered ecosystem and the PPR portion alone is responsible for producing 50-80 percent of the continent's waterfowl, while accounting for only 10 percent of the available breeding habitat. It is estimated that less than 1 percent of Minnesota's historic native prairie remains intact, with much of the remnant prairie scattered in small clusters. Restoration of key sites within this landscape has been identified as the most important strategy to create a contiguous expanse of prairie/wetland mosaic and to improve the ecological functioning of these systems.

In the fall of 2000, The Nature Conservancy (TNC) purchased the 24,000-acre Glacial Ridge property near the town of Crookston, Minnesota. Native cover and the natural functioning of over 90 percent of the property (22,000 acres) had been degraded or eliminated, primarily through conversion to row-crop agriculture, wetland drainage activities, and gravel-mining operations. The purchase and subsequent restoration of this property provide native habitat and connect nearly 7,800 acres of existing native prairie and wetland communities. The project has become part of a mosaic of protected lands in the area, connecting several other ownership parcels that harbor native plant communities. In addition to supporting wildlife, the project has water-quality benefits to the nearby town of Crookston and likely contributes to flood control along the Red River of the North. The TNC group subsequently transferred the property to the U.S. Fish and Wildlife Service (USFWS). The Glacial Ridge property makes up the majority of the new Glacial Ridge National Wildlife Refuge (NWR). The Glacial Ridge NWR was established in October of 2004 and has a planned final size of 37,756 acres. The Glacial Ridge restoration project has been identified by the USFWS as the largest tallgrass prairie and wetland restoration project in U.S. history.

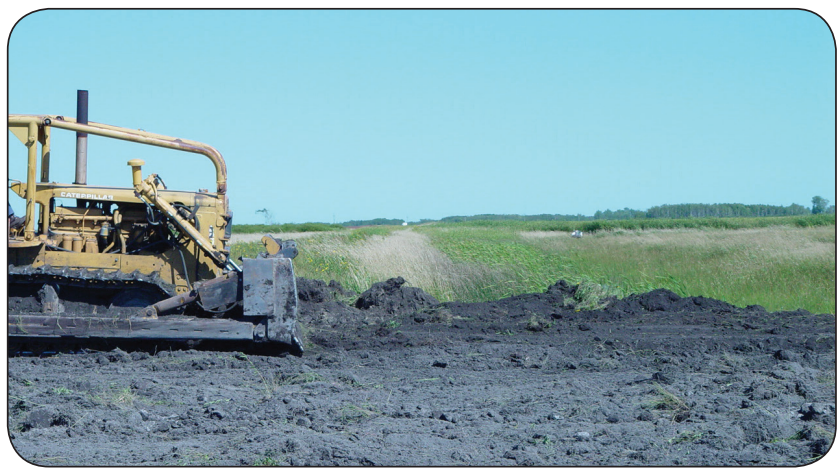

A bulldozer fills a drainage ditch as part of a wetland restoration on the Glacial Ridge property. Photograph by Jason Ekstein, The Nature Conservancy, 2005.

Economic Impacts. - Restoration of the Glacial Ridge property began in 2001 and concluded in 2011. Through funding provided by more than 20 partner agencies/organizations, including significant contributions from the USFWS and U.S. Department of Agriculture's Natural Resource Conservation Service, restoration and management activities brought substantial and consistent economic benefits to the surrounding rural counties in northwestern Minnesota each year over the course of this 11-year project. Yearly project expenditures averaged about $\$ 2.2$ million (2011 dollars). These expenditures directly supported six jobs in the local communities surrounding the property and provided $\$ 476,000$ in local labor income (salaries, wages, and benefits) each year. It is estimated the Glacial Ridge project indirectly supported nine additional jobs each year, which provided $\$ 363,000$ in local labor income. The Glacial Ridge project also supported the creation of new small businesses. Each year the project purchased over $\$ 430,000$ worth of native plant seed from local vendors. Four new seed supply businesses and a new seeding and mowing business were created to meet this substantial new demand. Other local vendors have expanded as a result of the new demand, with two new seed-storage sheds built at one company and new seed-cleaning equipment purchased at another. 
The PFW program in the region is estimated to contribute 160 jobs each year. Model results for labor income and value added generated by the program are $\$ 5.8$ million and $\$ 7.8$ million, respectively. Combined, system operations and restoration efforts through the USFWS NWRS and PFW program are estimated to contribute around 850 jobs each year just within the economy of the PPR. Again, those estimates don't include the job and income effects from visitation, recreation, and other permissible uses.

As with our recreation estimates, the contributions presented in table 2-4 certainly do not account for all the habitat restoration and maintenance taking place in the region. The analyses presented simply show the economic contribution of a few select programs with a presence in the PPR. Other programs that employ habitat restoration such as the Conservation Reserve Program (CRP) and Wetland Reserve Program (WRP) undoubtedly add to these figures.

One final point that should be discussed when addressing the value of perennial habitat lands, which is not captured in the analyses above, is the concept of net economic benefit or consumer surplus. These concepts refer to the fact that people are often willing to pay much more than they currently must pay. To further clarify, most recreational activities or natural amenities such as scenic view-sheds do not carry a market price per se, such as does an item you would buy at a grocery store. Instead, modelers commonly rely on revealed behavior to appraise values, such as the out-of-pocket money people spend to travel to go hunting or camping at a particular spot (for example, gas, lodging, food, equipment, licenses, etc.). Those expenditures, however, do not represent the total value people have for a particular activity, place, or amenity. A net economic benefit, or consumer surplus, arises when folks are willing to pay more than they currently must. People typically maintain a much higher value for recreational experiences and the ability to pass on such experiences to future generations than the cost expressed through current purchases. When considering the value of certain natural amenities that don't have clear market attributes, this net economic benefit should be recognized as well. 


\title{
Chapter 3: Land Use and Rural Development
}

\author{
By William Gascoigne ${ }^{\mathrm{a}}$ and Rex Johnson ${ }^{\mathrm{b}}$
}

Rural development has been an on-going effort for decades. This effort spans from the floors of the federal legislature all the way to town-hall meetings. The policy discussion around rural development in America has been at the center of academic and professional careers and the mission statements of many nonprofit organizations. While there seem to be significant resources devoted to this agenda, rural communities in much of the U.S. continue to witness decline in economic indicators vital to sustainable community health. Decreases in the available workforce, increases in farm consolidation, higher median age, outmigration of younger generations, and deteriorating infrastructure are observable trends. Even after 70-plus years of federal farm policy efforts heavily targeting the agriculturalists residing in rural towns, the prosperity imbalance between rural and urban America continues to widen (Miller and Rowley, 2002). These trends have garnered additional research into the larger issue at hand, with researchers typically focusing on one or a small subset of influential drivers. In this chapter, we summarize and analyze findings regarding rural-development trends as they pertain to landscape conditions. Two main questions are investigated. First, how is rural community well-being tied to landscape conditions? And second, does investing in a community's ecological health result in greater community well-being?

In addressing the first question, this report aims to provide an extensive review of research findings as they pertain to aspects of community well-being. Examples include job and income growth, migration patterns, and community resiliency. Linkages to the landscape include those that are direct (for example, cleaner environment directly impacts personal health, as an aspect of well-being) and indirect (for example, naturebased tourism can reflect levels of land-use conversion and may impact various jobs in that industry). The findings of this chapter build on the discussion points presented in chapter 2 .

The second question proposed is much more challenging to answer. The fact is, rural communities are quite diverse. In this respect, investing in natural resources - as with any rural-development strategy — may be appropriate and successful in one community but not in another. Research investigating why some rural communities prosper while others do not shows there is an array of influential factors (Aldrich and Kusmin, 1997; Isserman and others, 2007). These include

\footnotetext{
U.S. Geological Survey
}

${ }^{b}$ U.S. Fish and Wildlife Service current population size, educational attainment proportions across populations, distances to urban centers, natural resource endowments, and the fundamental character of the economic base. Some of these attributes are outside the realm of public policy and uncontrollable, such as local climate conditions and topography (see, for example, Cromartie, 1998). Ultimately, each community must assess their own assets and move forward in ways in which those assets are strengthened.

Perhaps the biggest challenge to answering this question is the fact that there is no universal definition of "community well-being." This makes statistical analysis very difficult, prone to modeling error, and it produces results that are quite arbitrary (Deller and others, 2001). In an attempt to define this term, researchers have looked into correlations with income levels, outmigration patterns, poverty levels, unemployment rates, and a handful of other variables (for example, DuffyDeno, 1998; Deller and others, 2001; Lewis and others, 2002; Goe and Green, 2005; McGrannahan, 2008; Eichman and others, 2010). These variables commonly are economically based and make up only a portion of this larger concept of community well-being. We instead aim to address this question more qualitatively and to present findings from the literature for review. Additional insight was gathered from informal conversations with local stakeholders.

While these questions are explored, it is important to understand how rural communities have evolved. Over time, the rural economy became synonymous with the farm economy. However, the number of farming-dependent counties in the U.S. has been shrinking (fig. 2-1 and table 2-2). Additionally, many researchers have concluded that technological innovations in the production process have resulted in lower labor inputs, leading to farm consolidation and continuous outmigration from agriculturally dependent communities (Bender and others, 1985; Albrecht, 1986, 1993; Beale, 1998; Johnson and Rathge, 2006; White, 2008). Agriculture in rural America, and in the PPR in particular, remains a very important component to the rural and national economies. However, more rural areas rely less and less on production agriculture, especially when it comes to the employment base (Drabenstott, 2003; Irwin and others, 2010). Additionally, a growing percentage of farm-household income is coming from off-farm sources (Fernandez-Cornejo, 2007). From a ruraldevelopment standpoint, it has been reiterated that policies targeting rural America must go beyond agriculture (Drabenstott, 
2000; Whitener and Parker, 2007; Irwin and others, 2010), and recent analytical research on quality-of-life fluctuations revealed even farmers in the Midwest felt a higher dependence on farm income was negatively associated with levels of quality-of-life (Arbuckle and Kast, 2012).

Economic development - as a major component of rural development - has both quantitative and qualitative dimensions. Quantitatively, economic development entails a growing economy with an expanding population, employment opportunities, and monetary income along with a higher dollar volume of business activity (Power and Barrett, 2001). Qualitatively, it leads to rising standards of living that contribute to the overall quality of life for a region's residents. This may take the form of higher household income, but it also includes improvements in public services and environmental and social amenities that may be equally or more valuable. These economic dimensions are also cyclical in nature. For instance, increased employment and associated wages can provide more disposable income for area residents to spend on recreational activities, with additional demands placed on providing and/or preserving those opportunities. On the other hand, research has shown that people often choose to reside in an area with abundant natural amenities, with companies and job opportunities soon to follow (Rudzitis and Johansen, 1989, 1991; Duffy-Deno, 1997, 1998; Power and Barrett, 2001; Dearien and others, 2005). This is especially true with the current generation entering the workforce (Power and Barrett, 2001; Ryan, 2007).

\section{Employment and Income Effects}

Land and resource management policies and programs are widely believed to shape the fortunes of local natural resource industries, farming included. Because these industries have been viewed historically as the engines driving local economic activity, many view policies and programs looking to retire cropland and/or protect native lands as undermining the local economy and destroying good jobs. Concerns have been expressed that such policies will cause higher levels of local unemployment, lower income levels, and generally lower overall economic well-being. At the same time, current research suggests that structural changes in the U.S. economy, and rural areas in particular, have reduced the economic role of production agriculture (for example, Walzer and Deller, 1996; Drabenstott, 2001; Johnson, 2001; Deller and others 2003).

The theory that a healthy farm economy equals a healthy rural economy is a concept that has been around for the last century. However, over that time period there have been significant changes to the structure of both the farm economy and the makeup of rural America. A majority of rural residents in the middle of the 20th century were engaged in farming in some respect. It was understandably contended that rural growth was led and determined by export demand for agricultural products (North, 1959). Following that logic, traditional economic models would have estimated a complete collapse of the nonfarm rural economy as a result of the sustained decline of the agricultural export-based employment since that time (Irwin and others 2010). Such collapse, however, was not observed (Deller and others 2003; Kilkenny and Partridge, 2009). Again, this broad notion of dependency would indicate nonfarm employment mirrors the growth and decline in farm proprietorship and employment (as measures of economic growth). Agricultural economist Steven Deller and others (2003) examined these relationships and found that the link between a declining farm sector and rural economic growth becomes blurred. Specifically, those authors determined for the past 30 years that the farm and nonfarm rural economies appear to have moved in opposite directions, at least in terms of employment growth and especially of late. The empirical results from Deller and others (2003) suggest that a higher level of dependency on production agriculture, either overall dependency or a greater portion of large farms, reduces growth rates of the rural U.S. economy. Additional research by Monchuk and others (2005) produced similar results.

Additional literature indicates that the farm economy is becoming more dependent on the health of the rural economy (Pulver and Rogers, 1986; Deller and others, 2003; Gardner, 2005). Gardner (2005) concluded that the integration of farm and nonfarm labor markets was largely responsible for slowing the decline in the number of farms. Of the 2.2 million farms nationwide, more than half depend on nonfarm income to remain financially viable (USDA Census of Agriculture, 2007). The proportion and amount of off-farm income received by farm operators and their spouses has risen steadily over recent decades. As noted in chapter 2, the off-farm share of total household income of U.S. farmers rose from about 50 percent in 1960 to more than 80 percent over the last 10 years (FernandezCornejo, 2007). Multiple variables are responsible for that trend, including technological progress that has lessened on-farm labor needs and the rising costs of farming inputs. This statistic highlights how a healthy, diversified rural economy is undeniably important to farming. As noted by Deller and others (2003), "the commonly held belief that a healthy farming economy translates into a strong rural economy has been turned on its head; rather, a strong rural economy is a necessary condition for robust farm household income."

Research into the impact of conserved/protected habitat on job and income growth indicates mixed results across locales, economic sectors, and research approaches. From an empirical perspective, natural amenity-based economic development appears to be an important determinant in employment and income growth (Kwang-Koo and others, 2005). A growing body of literature suggests natural amenities are correlated positively with economic growth variables (Duffy-Deno, 1997, 1998; Rudzitis and Johnson, 2000; Deller and others, 2001, 2005; Power and Barrett, 2001; Monchuk and others, 2005). For instance, Monchuk and others (2005) analyzed regional growth patterns in the Midwest and found recreational amenities - both those created locally and those 
provided by the federal government- - had a positive and significant impact on county economic growth (as defined by per capita income). Looking more specifically into the impact of protecting land, Kroeger (2008) revealed that out of eight studies looking at income/output impacts from protecting natural landscapes, six indicated positive impacts, two concluded insignificant impacts, and no studies showed negative impacts. Similarly, of 11 studies looking at employment impacts of protecting land, nine determined positive impacts, two had insignificant results, and none indicated negative employment effects.

In terms of the CRP, program payments can be a way for landowners to diversify their income. Those payments are not susceptible to harsh weather events or the daily ups and downs of a global economy. Also, the program targets highly erodible, environmentally sensitive lands that likely are more marginal in terms of crop production. Furthermore, the classical economic concept of "Willingness to Accept" suggests that landowners wouldn't enroll their lands if they would be better off farming those acres. Assuming they are profit-maximizers, while also accounting for risk and other operational attributes, landowners wouldn't enroll if they didn't think they could make more money or achieve as much value with those certain acres in tillage agriculture. Mortensen and others (1989) reported that around 80 percent of contract holders surveyed agreed that CRP benefited them financially, and 20 percent indicated the program enabled them to continue farming. With near record-level commodity prices and uncertainties revolving around government funding for conservation, these results may not represent future viewpoints.

While empirical evidence shows positive correlations between economic growth and conserving and/or protecting specific natural landscapes, other research cases exist in which no significant correlations were determined; some show certain economic sectors were impacted negatively. For instance, Lewis and others (2002) ran a model that examined the relationship between employment growth and nonmetro county proportion of protected lands (that is, national or state parks and forests, wilderness areas, and wildlife refuges) in northeastern New York and northern New England. The study results suggest that the share in conservation lands had no direct effect on employment growth. Eichman and others (2010) reviewed the Northwest Forest Plan (Federal policy series, adopted 1994), which reallocated 11 million acres of federal land from timber production to protecting oldgrowth forest species, and found evidence that land protection directly reduced local employment growth. Additionally, some research indicated retiring lands through the CRP can have negative job growth impacts on various economic sectors (Martin and others, 1988; Van der Sluis and Peterson, 1994, Bangsund and others, 2004; Strege, 2009). Needless to say, the job- and income-growth effects of protecting land are not uniform. Local impacts will be determined by existing social and economic structure, as well as the specific parcel under proposal.

\section{Population and Migration Patterns in the Prairie Pothole Region- Cause and Effects}

Rural depopulation continues to be a major concern in the rural-policy community. Nearly half of the Nation's 2,050 nonmetro counties lost population through net outmigration between 1988-2008, with nearly a third of those counties losing 10 percent or more (McGranahan and others, 2010). Figure 3-1 shows that most of this decline has taken place in the Great Plains, including the PPR in the northern portion (fig. 1-1). There is, however, no single underlying cause or policy solution to this social endemic. In some counties with a long history of high outmigration, the loss is exacerbated by "natural decrease," an excess of deaths over births in an area with an aging population (McGranahan and others, 2010). In such a case, community officials must gear their efforts not only to maintaining their younger residents but also to attracting younger citizens from outside the area.

Again, the research largely suggests that no single set of characteristics differentiates high outmigration counties (for example, Cromartie, 1998; McGranahan, 1999; Irwin and others, 2010; McGranahan and others, 2010; Chi and Marcouiller, 2011). While some rural counties experiencing outmigration struggle with high unemployment, low education, and high poverty, a majority of rural counties suffering from population decreases have a relatively well-educated resident base and below-average unemployment rates when compared to other parts of the country. McGranahan and others (2010) examined the relationship between poverty and high net outmigration and found that this relationship only held true within counties with poverty levels over 25 percent; on average, outmigration of the working-age segment was not tied significantly to poverty levels. Outmigration commonly is related to relatively uncontrollable variables such as geographic isolation and lack of natural amenities tied to an area's climate conditions (Cromartie, 1998; McGranahan, 1999; McGranahan and others, 2010).

Research on rural America from USDA shows that while new rural jobs attract people, it is equally true that migration to rural areas promotes job growth (McGranahan and Sullivan, 2005). Gottlieb (1994) concluded that there was little evidence that amenities directly induce employment growth, but instead, amenities attract migrants into an area who demand additional goods and services and thereby create new job opportunities. Additional research looking into migration patterns in the Mountain West also supports these findings that people often choose to live in a particular area based on non-employment characteristics such as natural amenities and quality-of-life attributes, with jobs to follow as that labor market grows (Power and Barrett, 2001). These migration patterns hold especially true with the generation following the Baby Boomers, a generation which traditionally followed job opportunities and tended to reside closer 


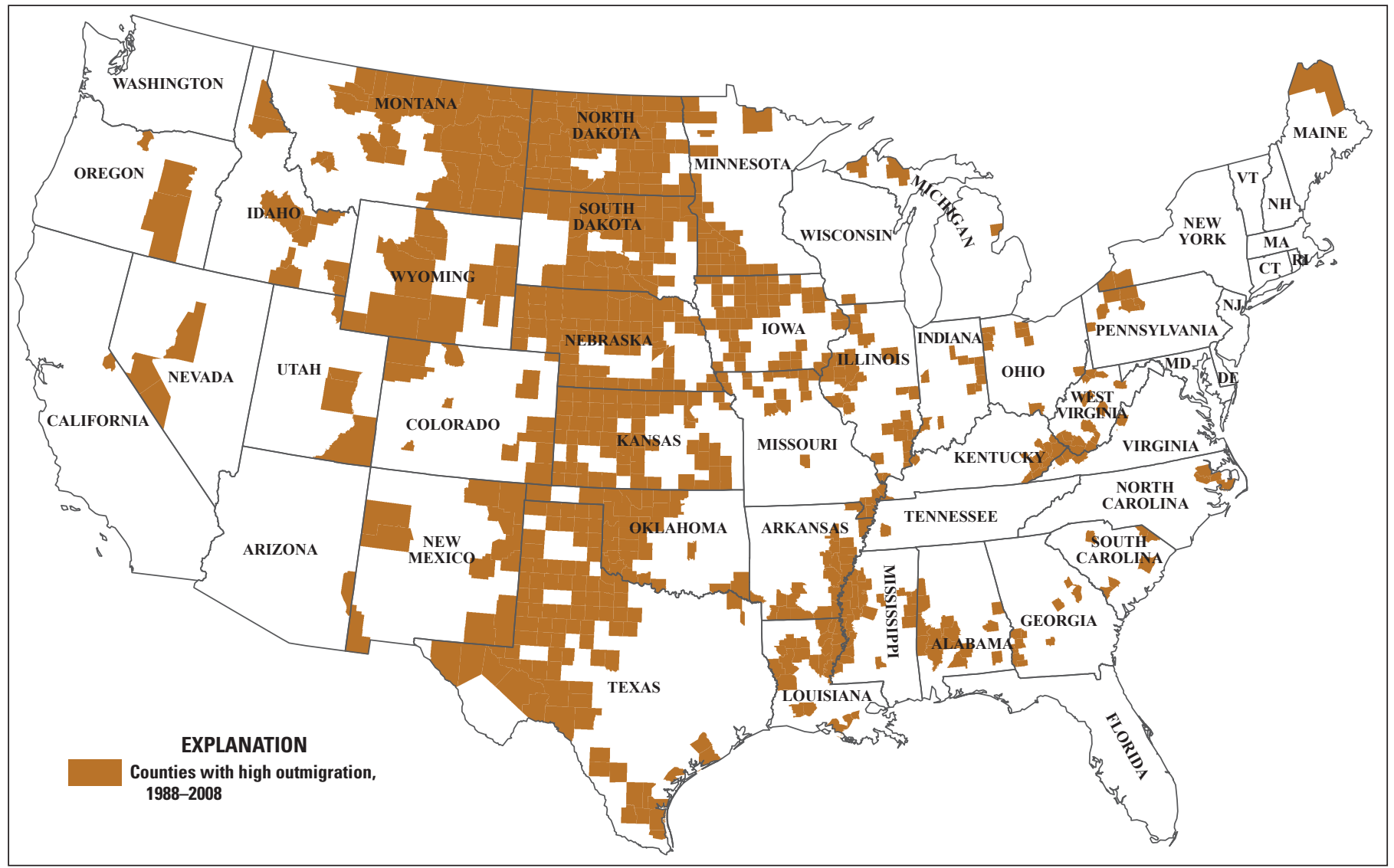

Figure 3-1. United States counties with high outmigration levels from 1998-2008. A county is classified as high outmigration if it had 10 percent or higher population loss from net migration. Modified from U.S. Department of Agriculture Economic Research Service, Atlas of Rural and Small-town America (2011). [Abbreviations here include United States mail-code state abbreviations]

to respective birthplaces (Ryan, 2007). This goes against neoclassical migration theory in which decisions were based solely on employment and income (Sjaastad, 1962). Younger generations essentially are demanding a larger suite of amenities, with natural amenities and recreational opportunities atop many lists. This demand is largely a reflection of the increased mobility of younger generations along with rising standards of living (Domon, 2011).

Additional research has been done on migration decisions as they relate to landscape conditions and preferences. McGranahan (2008) draws on landscape-aesthetics research to examine how landscape features have shaped rural county migration in the U.S. since 1990 and suggests that the elements of preferred landscapes have been major factors in recent rural migration. The results of his research show that landscape features influenced migration directly, with people being drawn to areas with a mix of forest and open land, water area, topographical variation, and relatively little cropland. Other empirical examples include Johnson and Stewart (2007), who found that between 1990 and 2000, the population residing in counties containing national forest land grew by 19 percent, compared to 13 percent for the country as a whole, mostly from net immigration. Gundars Rudzitis (1996) analyzed counties adjacent to federally designated national wilderness areas and found population growth patterns well above the national average. Results of two other national-level studies (Deller and others, 2001, 2005) and a northern Lakes States regional analysis (Lewis and others, 2002) also found that areas with greater shares of protected lands were associated with a higher likelihood of growth in population.

Cantrell and others (2008) asked new migrants to Nebraska's rural panhandle how important different factors were in their decision to move to the area. Forty percent of respondents previously living in a metropolitan area and 30 percent of nonmetro migrants indicated their intentions to move to an area with a more desirable natural environment. Likewise, 25 percent and 30 percent of metro and nonmetro respondents, respectively, indicated a key factor to them moving to the area was to find an area that offered more outdoor recreation opportunities. This was also a response heard from individuals migrating out of the rural town of Hugo in Colorado's eastern plains. Among employment opportunities and housing concerns was the response that there were declining outdoor recreation opportunities (Rural Community Assistance Corporation, 2011). These results indicate that, depending on which lands are removed from production and 
the land cover that follows, conservation programs such as the CRP could support rural community viability by enhancing scenic and recreational appeal for potential migrants, tourists, and current residents.

During conversations with county commissioners located in the PPR, many noted their sons or daughters have moved away. They have cited both economic (that is, job opportunities and higher wages) as well as social factors (for example, "more things to do," access to sports teams, and other forms of entertainment). The harsh economic climate of late likely has placed greater emphasis on economic variables, as witnessed in the new in-migration figures in parts of North Dakota mirroring the increase in oil and gas production in the region and the increase in job opportunities that have followed. This in-migration has occurred in a region that has suffered from outmigration for decades and was an area identified as a Rural Economic Area Partnership, vying for federal funding to address development issues. In that light, economic opportunities certainly carry weight.

Numerous researchers have pinned outmigration to advances in farm technology (Simon, 1947; Bender et al, 1985; Albrecht, 1986, 1993; Beale, 1998; Johnson and Rathge, 2006; White, 2008; Irwin and others, 2010; Domon, 2011). That is, new technology has increased efficiency and reduced the demand for labor, thereby reducing employment opportunities in agriculture-dominated regions such as the PPR (fig. 2-1). Gains in efficiency also are seen through farm consolidation. While consolidation typically increases production volumes, it concurrently displaces farm populations (Kulcsár and Bolender, 2011). When there is a relative lack of alternative employment opportunities, as is commonly the case in farm-dependent counties, outmigration typically occurs (Johnson and Rathge, 2006). Such outmigration can spark a cycle in which demand for local goods and services is reduced and ultimately more outmigration is observed (see table $3-1$ ).
Reductions in agricultural labor demand also have made it more difficult for the next generation to take over the farm, especially when there are multiple siblings. High commodity prices recently have increased the profitability of farming, yet those prices are commonly paralleled by high prices for land. The high land prices can create a challenge to future farming generations and inhibit retention of younger folks interested in working in the industry. Research has shown that government payments have had little effect toward diminishing outmigration patterns in rural areas (Goetz and Debertin, 1996; McGranahan and Sullivan, 2005; Whitener and Parker, 2007). For example, the high level of farm payments in the late 1990s did little to eliminate long-term outmigration from farming areas. Research shows that counties with heavy dependence on farm payments have had some of the highest rates of population loss, even during periods when most other rural areas were gaining population. As noted, this loss might have more to do with changes in farming itself than other variables. Furthermore, mainstream theory in agricultural and policy economics suggests government payments get treated as a source of income and ultimately get capitalized into land prices. Their effect becomes marginalized and relatively ineffective in addressing farm profitability and incentivizing younger generations to stay in the business. Empirical research supports this theory to a certain degree with recent estimates indicating that between 35-45 percent of the marginal-subsidy dollar ends up in increased rental rates (Kirwan, 2009).

Ultimately, in choosing were to live, most people value both economic opportunity (that is, jobs, wages, and potential clientele) and such area amenities as schools and other public services, environmental conditions (clean air and water), open space and landscape aesthetics, and opportunities for outdoor recreation. Such attributes constitute an area's quality of life. It is not uncommon for people to weigh the non-income attributes just as highly as or higher than potential income

Table 3-1. Estimates of city population required to support an indicated number of establishments of selected business types, North Dakota, 2000. Modified from Coon and Leistritz (2002).

\begin{tabular}{|c|c|c|c|c|}
\hline \multirow{2}{*}{ Business type } & \multicolumn{4}{|c|}{ Number of establishments } \\
\hline & 1 & 2 & 3 & 4 \\
\hline Eating places & 212 & 344 & 483 & 890 \\
\hline Grocery stores & 702 & a & a & a \\
\hline Farm and garden machinery and equipment & 579 & a & 612 & 706 \\
\hline Farm supply stores & 575 & 623 & 819 & 1,089 \\
\hline Lumber and other building material shops & 1,020 & 1,167 & 2,140 & 3,929 \\
\hline Home furniture & 1,640 & 2,589 & 4,647 & 7,815 \\
\hline Radio, television, and consumer electric stores & 1,602 & 4,712 & 7,823 & 10,933 \\
\hline Florists & 1,287 & a & 3,373 & 4,171 \\
\hline Drug stores & 1,022 & 2,141 & 3,763 & 5,886 \\
\hline Family clothing stores & 1,928 & a & a & a \\
\hline
\end{tabular}

${ }^{a}$ Not estimated because the data set contained insufficient numbers to support reliable estimates in these categories. 
levels. In making decisions on where to live and work, people will choose the mix of market and nonmarket characteristics they regard as best for their families and themselves. This is a classical economic proposition, which simply becomes a balancing act. In this light, if wages and employment opportunities were to decline, it would be paramount for a community to try to increase factors of quality of life. This is not to say that good wages and a high quality of life are always mutually exclusive. Instead, the takeaway point is that people value more than just wages and will make decisions on where to live based on a myriad of variables. A community has the potential to experience declines over time if it becomes too narrowminded. As noted by author John Cromartie (1998):

Public efforts to enhance and protect the quality of social and natural environments are also essential in declining communities, even though they may be perceived as putting intolerable burdens on fragile public budgets. Great Plains counties often are in decline because they do not have local qualities and characteristics that allow them to attract and hold residents. To allow the local and social and natural environments to deteriorate can only make things worse and delay any recovery. Poor schools, run-down public and private infrastructure, polluted water or air, toxic waste deposits, or other threats to public health and safety simply dig the community into a deeper hole. The importance of local amenities can be seen clearly even on the Great Plains. The areas in that region that have been able to resist general decline are those with natural amenities that have allowed them to recruit population and economic activity despite declining opportunities in agriculture.

Additionally, many people live in the PPR for its rural way of life and small-town amenities. Needless to say, high quantitative growth is not necessarily better. This is apparent in recent growth in the Williston Basin of northwestern North Dakota from expanding oil and gas development. While job growth and outmigration patterns are no longer of concern, there have been significant increases in crime (both criminal and environmental), shortages in housing availability, and tremendous strain placed on various municipal services. The North Dakota state court system's annual report shows criminal filings in the Northwest Judicial District of the state jumped by nearly one-third, from 5,581 cases to 7,390, from just 2010 to 2011 (North Dakota Court System Annual Report, 2011). Criminal filings are accelerating even more into 2012 , with first-quarter figures showing a nearly 50 percent increase compared to the first three months of 2010. Traffic cases are up almost 75 percent, further bogging down clerk offices and judges (Nowatzki, 2012). These trends show that the overall effect of quantitative growth on well-being is, at best, ambiguous. Instead, to directly serve the public interest, rural localdevelopment policies must raise living standards, including pay and the quantity and/or quality of local amenities (Power and Barret, 2001).
The amount of research devoted to understanding rural development and outmigration patterns is well deserved. The impacts of outmigration flows are widespread and diverse. Fundamentally, maintaining population levels is critical to maintaining business proprietors, schools, and other amenities. Coon and Leistritz (2002) examined 161 communities in North Dakota to determine the minimum population level required to support various types of businesses at an acceptable return or profit, what also is referred to as "threshold population level" (table 3-1).

Results from Coon and Leistritz (2002) indicate how even small decreases in population can impact the market threshold for local businesses. Larger decreases can have a destructive cyclical effect; that is, as people leave, towns tend to grow more economically unstable, making it tougher to initiate rural community-development projects that could make the area more appealing to current and future residents. The ability to come together as a community to face challenging issues, encapsulated in concepts of social capital and civic engagement, often wanes, becoming more and more daunting to relieve (Coleman, 1988; The Saguaro Seminar, 2000). When speaking to a South Dakota county commissioner about the well-being of rural communities, he immediately alluded to the value of such concepts, noting his community's ability to raise and support a scholarship fund at the local high school, something he thought was very indicative of a healthy community. This perspective towards the importance of community vitatlity was recently documented quantitatively by work at Iowa State University (Arbuckle and Kast, 2012).

Furthermore, population levels are obviously tied to the tax base. While municipal service demands theoretically decline as populations decrease, this is not always the case. Some utilities are not as disposable as others. Schools, government buildings, and other municipal responsibilities cannot simply be 'turned off,' and reductions typically are not proportional. This is especially true when there are large surges in populations and municipal demands with anticipated declines in the future. This is one of the major concerns with development around the oil and gas production boom that inevitably has a timeline, with workers and their tax revenues likely to fall in the future.

\section{Community Sustainability and Resiliency}

As described in chapter 2, the rural economy over the past 40 years has been compared to a roller coaster (Deller and others, 2003). Rural areas experienced relatively strong economic growth in the 1970s, 1990s, and mid-2000s, yet employment was stagnant in the late 1970s and much of the 1980s as employment grew in more urban parts of the country (Deller and others, 2003). More recently, many rural areas endured the national recession from 2009-2011 fairly well, with relatively low unemployment rates throughout 
the northern Great Plains (U.S. Department of Agriculture Economic Research Service, 2011b). Many rural communities continue to struggle, however, with outmigration, farm consolidation, deteriorating infrastructure, and respective municipal balance sheets. The harsh economic climate of late has increased the need for immediate job creation; rapid development, however, initially can strain local communities and be difficult to sustain. The oil-production boom has local governing boards in the Williston Basin struggling to balance job growth, manage crime, and meet municipal service demands, while not overinvesting in long-term infrastructure nor allowing rampant environmental degradation.

The 1980 decade was very turbulent for farm communities in the Midwest. The financial calamity in agriculture during that period caused many farmers to lose their operations, and local businesses struggled to stay in business. Authors Rand Conger and Glen Elder interviewed Midwestern farmers and local stakeholders following that period, providing the insight for the book, Families in Troubled Times (Conger and Elder, 1994). In the book, the authors note the following observation: "The message seems clear. As a citizenry, we will need to become more capable of adapting successfully to economic uncertainty and change." In other words, these authors touched on the importance of resiliency as it pertains to the long-term, sustainable health of rural communities.

A standard concept in investing is that diversity essentially reduces risk, and from an early age, one commonly hears the expression, "Don't put all your eggs in one basket." Diversification is described in the investment world as a riskmanagement tool that works to hedge against other investments, which ultimately reduces the risk inherent in any one investment (Farlex Financial Dictionary, 2012). This is an investment concept that not only applies to Wall Street finance but also to individuals investing in their own operation or business, community leaders in charge of investing, managing, and promoting private and public operations, and even people investing in conservation and species survival. Citizens of the PPR are more than aware that threats to their economic well-being come in many forms. Those include institutional and policy changes, more general economic shifts in supply and demand, and certainly such natural events as floods and droughts. As diversification reduces risk to such threats, it also enhances adaptability (Grigsby, 2001).

One also hears the analogy, "Risk equals reward." This references the boom cycles of timely investments in particular arenas, a concept often inherent in entrepreneurs with limited capital and a near-term outlook or investors with a stockpile of capital who are able to absorb financial blows (Hoag and Parsons, 2010). Ultimately, the appropriate analogy to follow is usually dependent on a number of factors, including an area's current endowment (natural and otherwise) and management timescale. For those in charge of investing in the long-term health of rural communities in the PPR (or anywhere else for that matter) they must ask themselves, "How risky do we want to be?"
Wagner and Deller (1998) suggested that the simultaneous pursuit of growth (through specialization) and stability (through diversification) are not contradictory when viewed in terms of the short and long runs. They suggested that, "policymakers pursue short-run strategies within the long-run policy of diversification," and, "diversification policies should be viewed as the long-run envelope of the region's short-run efforts." When examined closely, the concept of diversity is not absent of specialization but instead reflects the presence of multiple specializations (Malizia and Ke, 1993). For instance, it might make sense for an area to focus on establishing certain production agriculture if that is its true competitive advantage. Over time the area could initiate other short-term strategies such as expanding the commodity base to include alternative commodities (livestock or even fallow ground), introducing value-added processing, and promoting input supply industries. One could add further diversity by then promoting industries complementary to uncultivated lands such as ecotourism and recreation. Those specializations will then support additional industries and so on. Again, short-term strategies can be geared towards specialized growth; however, the key for longterm health is to have diversity within those strategies.

When separately discussing the current health of rural communities in southwestern Minnesota with two respective county commissioners, they both agreed it was healthy, "given that commodity prices are so good right now." To them, the health of their community was highly correlated to crop prices and relative farm income, two variables that are tied largely to outside factors beyond one's control and two variables that rarely remain stagnant. Agriculture tends to be a volatile industry, notoriously experiencing ups and downs, more notably referred to as "booms and busts." The expanding global economy has resulted in new and growing markets, while also making local revenues susceptible to additional variables beyond one's control.

A review of the boom and bust cycles in agriculture has identified correlation to debt structure within farm operations (Henderson and others, 2011). As enterprises experience good returns and land values begin to increase, operators generally will invest in additional infrastructure and equipment and feel comfortable taking on the additional debt. Existing debt is sometimes used to finance new investments. It is this situation with growing debt and leverage following strong prices, low interest rates, and rising land values in which there tends to be a bust cycle soon to follow (Henderson and others 2011). In the last few years, prices have been strong, export activity has surged, and interest rates have reached all-time lows. While this seems to be the recipe for past bust cycles, the extent will likely depend on the ability of farmers to maintain financial leverage while confronting narrowing profit margins in the near future, as is expected. A recent report from the Federal Reserve Bank of Kansas City (Henderson and Akers, 2012) indicates farm lending is rising as capital spending and farmland investments continue to increase of late. This begs the question, "Is the farming industry setting itself up for another bust in the near future?" 
In recent decades, agricultural and regional economists emphasized the economic diversity of rural places and negated long-term prosperity with static notions of sector prosperity (Barkely, 1993; Johnson, 1997, 2001; Isserman, 2001; Irwin and others, 2010). One of the same two county commissioners in Minnesota mentioned above seemed to be much more convinced his county was in a 'healthy' state, noting the presence of a packing facility and small-engine manufacturing plant, both of which were doing well and continuing to be major employers. This response is on par with suggestions of Wagner and Deller (1998) and the value of diversification to sustainable economic health.

\section{Local Tax and Fiscal Considerations}

One of the major concerns regarding land conservation is the issue of property taxes and the inherent revenue stream for municipalities. Local governments collect revenue through intergovernmental transfers, property taxes, sales taxes, personal income taxes, and other charges such as permitting. Municipalities depend on these revenues to fund community services such as fire and police services, schools, infrastructure, and other public amenities. Property taxes constitute the largest source of local governments' own revenue (Urban Institute and Brookings Institution, 2008). When land ownership is transferred to the government or to nonprofit entities, the responsibility to pay property taxes on that parcel is waived. However, lands under federal ownerships typically do provide some payment in lieu of taxes (known as "PILT" payments). Additionally, nonprofit organizations working in the PPR such as Ducks Unlimited (DU) and The Nature Conservancy (TNC) have opted to pay property taxes in certain instances (for example, the Glacial Ridge restoration project in Polk County, Minnesota), or in the case of DU, on all of their properties.

The U.S. Fish and Wildlife Service is the largest federal landowner in the PPR. The Refuge Revenue Sharing (RRS) Act of 1935 allows the USFWS, although tax exempt, to make annual payments to local governments in areas where fee-title purchases have removed land from the tax rolls. Under provisions of the RRS Act, local counties receive an annual payment for lands that have been purchased by full fee-title acquisition by the USFWS. Payments are based on the larger of 75 cents per acre or 0.75 percent of the fair-market value. The exact amount of the annual payment depends on Congressional appropriations, which in recent years have been substantially less than the amount required to fully fund the authorized level of payments. For the years 2001 through 2009, RRS payments averaged 46.5 percent of the full 0.75 percent of the fair-market value and declined seven times in that time period. In FY 2009, actual RRS payments were 30.7 percent of authorized levels and in FY 2010 actual RRS payments were 22.9 percent $^{1}$ of authorized levels, indicating an ongoing downward trend. With tightening federal budgets, RRS payments may continue to dwindle in the future.

Conservation easements are another tool used by conservation organizations and agencies. A conservation easement is a voluntary legal agreement entered into between the landowner and a conservation entity. Under the agreement, the landowner receives financial compensation and/or incentives to forego certain rights on the land, such as future development and certain production practices. The landowner maintains ownership of the land and the rights to sell or bequeath the property, while the agreed-upon restrictions remain in perpetuity. Because the land remains in private ownership under a conservation easement, the property remains subject to municipal taxes. Tax laws and the assessment of land vary by state; conservation easements, however, typically do not have substantial impact on municipal revenues.

While protecting lands through federal fee-title ownership likely will reduce municipal revenues, those lands commonly require fewer local government services and would thus represent lower overall costs to local governments (American Farmland Trust, 2010). Therefore, the actual net fiscal effect of government land acquisition may be lower than initially perceived. When talking to a county commissioner in southwestern Minnesota about the challenges his county currently faced, he was quick to point out the declining infrastructure, namely roads and bridges. He discussed how the recent increase in grain production was straining the county's transportation infrastructure, as more semi-trucks and large machinery were traveling county roads not designed for such weight. Similar effects have been described up in northwestern North Dakota from the surge in trucking related to oil and gas production (Holeywell, 2011). For perspective, each oil well requires, on average, 2,200 semi-truck visits to service the well over its lifetime (Yamanaka, 2012). With over 8,200 active oil wells in North Dakota alone (as of 2012), that equates to more than 18 million truck loads just to service current production levels. Overall, local municipal revenue streams continue to be a real and important area concern; one must, however, also factor in the alternate costs associated with various land uses.

\section{Conclusions Regarding Land Use and Rural Development}

There are many aspects to rural development, with landuse decisions being one of them. It is important for policy makers to realize how land-use decisions relate to economic variables such as jobs, income, and population patterns, as well as to dynamic issues such as community resiliency. In

\footnotetext{
${ }^{1}$ This percentage was calculated using actual payments made to counties within the Prairie Pothole Region and may vary slightly from the national average.
} 
the past, agriculture has always been the starting point for discussing the rural economy, and for good reason. Ruraldevelopment specialists, however, have recognized that agricultural policy alone no longer can address the economic challenges facing most rural Americans (Drabenstott, 2001, 2003; Whitener and Parker, 2007, Irwin and others 2010). Modern rural-development policy must go beyond agriculture and take sight of other aspects of rural communities, while considering long-term health.

The impacts of protecting and restoring natural landscapes can vary across regions, timeframes, and economic sectors; however, research shows there are often economic gains to be had. Continued conversion of fragile grasslands and wetlands not only pose environmental threats but also threatens rural economies and their potential development, as is recognized by the Center for Rural Affairs (2012). Rural development has both quantitative and qualitative dimensions. Economic growth and in-migration in rural areas undoubtedly provide positive benefits. Other qualitative aspects of community well-being, however, have been brought to the forefront by the recent and ongoing oil and gas boom in northwestern North Dakota. Policy makers must think holistically, recognize potential impacts from land-use decisions, and be willing to adapt to socioeconomic trends developing in response to local conditions. Ultimately, land-use and economic diversity enhance a community's ability to adapt.

Empirical research has shown that jobs follow people just as or more often than people follow jobs. The recent economic climate has certainly illuminated the value of and need for employment opportunities. Nonetheless, as people move to an area they create additional demand for goods and services that leads to additional business and employment opportunities. In that respect, policy makers must focus not only on attracting businesses to an area to spark economic growth but also must concentrate on attracting (and retaining) laborers to an area.

Research shows the importance of maintaining natural amenities and providing outdoor recreational opportunities to residents and potential migrants. This is particularly true with the current generation entering the workforce. Increased mobility and rising standards of living have young adults weighing these 'non-economic' variables just as much or more than income levels. As McGranahan and Sullivan (2005) reported, "Young adults with children (or older adults in retirement) will not flock to rural areas for high income. Instead, they will do so to seek a high quality of life, which encompasses schools, community life, pleasant landscapes, and opportunities for outdoor recreation, all of which will contribute to the economic vitality of the area." Rural areas in the PPR have great potential to promote their natural view sheds, area wildlife, and outdoor recreation opportunities as resources for further economic development. Area amenities are expected only to increase in importance and economic value into the future as demand for outdoor recreation grows with rising incomes, urbanization, leisure time, and population levels (Monchuk and others, 2005; Otto and others 2007). Without maintaining and/or enhancing the availability and quality of various amenities, rural communities in the PPR likely will continue to witness the outflow of young, educated persons (Otto and others, 2007).

Two questions were investigated in this chapter. First, how is rural community well-being tied to landscape conditions? And second, does investing in a community's ecological health result in greater community well-being? Discussion points and empirical results laid out in this chapter, as well those in chapter 2 , show clear relationships between landscape conditions and rural community wellbeing (economic and otherwise). We focus primarily on the relationship between natural landscapes and well-being, as those linkages (especially economically speaking) commonly go unnoticed. This emphasis is not intended to downplay the relation production lands have with rural communities. Working landscapes and employment in traditional industries such as farming are very important to rural communities in the PPR. This chapter aims to provide additional knowledge regarding the impact of conservation and the role of landscape diversification.

As noted at the beginning of the chapter, the second posed question is more challenging to answer than the first. Numerous peer-reviewed empirical studies have shown job growth and income influenced by the level of natural amenities provided in an area. Additionally, a number of quantitative and qualitative studies show that factors such as outdoor recreational opportunities are extremely important to individuals in choosing where to live and work. However, one must use caution when applying the results from one particular place and time to the entire PPR and to all included communities. The difficulty around this question largely is due to the ambiguity of the term "well-being," which can vary by person and town. Without a clear definition, it is hard to measure changes and identify statistical relations necessary to answer such a question. Local policy makers must be aware of what constitutes well-being for their residents, and prospective residents and must understand the dynamics of land-use change. This is no simple feat. We hope the information provided in this chapter helps with this understanding and adds insight useful to local decision makers. 



\section{References}

Albrecht, D.E., 1986, Agricultural dependence and the population turnaround-Evidence from the Great Plains: Journal of the Community Development Society, v. 17, no.1, p. 1-15.

Albrecht, D.E., 1993, The renewal of population loss in the nonmetropolitan Great Plains: Rural Sociology, v. 58, p. 233-246.

Aldrich, L., and Kusmin, L., 1997, Rural economic development-What makes rural communities grow?: U.S. Department of Agriculture Economic Research Service, Agricultural Information Bulletin, no. 737, 7 p.

American Farmland Trust [AFT], 2010, Cost of communityservices studies fact sheet: American Farmland Trust Farmland Information Center, August 2010, unpaginated. Available at http://www.farmlandinfo.org., accessed February 11, 2013.

Allen, A.W., and Vandever, M.W., 2012, Conservation Reserve Program [CRP] contributions to wildlife habitat, management issues, challenges, and policy choices-An annotated bibliography: U.S. Geological Survey Scientific Investigations Report 2012-5066, 185 p.

Arbuckle, J.G., Jr., and Kast, C., 2012, Quality of life on the agricultural treadmill - Individual and community determinants of farm family well-being: Journal of Rural Social Sciences, v. 27, no. 1, p. 84-113.

Bangsund, D.A., and Leistritz, F.L., 2003, Resident and nonresident hunter and angler expenditures, characteristics, and economic effects, North Dakota, 2001-2002: North Dakota State University Department of Agribusiness and Applied Economics Report, no. 507, 117 p.

Bangsund, D.A., Hodur, N.M., and Leistritz, F.L., 2004, Agricultural and recreational impacts of the Conservation Reserve Program in rural North Dakota, USA: Journal of Environmental Management, v. 71, p. 293-303.

Barkley, D.L., 1993, Economic adaptation-Alternatives for nonmetropolitan areas: Boulder, Colo., Westview Press, 298 p.

Batt, B.D.J., Anderson, M.G., Anderson, C.D., and Casewell, F.D., 1989, The use of prairie potholes by North American ducks, in van der Valk, A.G., ed., Northern Prairie Wetlands: Ames, Iowa, Iowa State University Press, p. 204-207.

Beal, C.L., and Johnson, K.M., 1998, The identification of recreational counties in nonmetropolitan areas of the USA: Population Research and Policy Review, v. 17, p. 37-53.
Bender, L.D., Green, B.L., Hady, T.F., Kuehn, J.A., Nelson, M.K., Perkinson, L.B., and Ross, P.J., 1985, The diverse social and economic structure of nonmetropolitan America: Washington, D.C., U.S. Department of Agriculture Economic Research Service, Rural Development Research Report, no. 49, 28 p.

Bogenschutz, T., and Roberts, S., 2010, 2009-2010 Small game harvest report: Boone, Iowa, Department of Natural Resources Boone Wildlife Research Station, Wildlife Bureau Survey Note, 5 p.

Brooke, Rebecca, Fogel, Gregory, Glaser, Aviva, Griffin, Elizabeth, and Johnson, Kristen, 2009, Corn ethanol and wildlife-How increases in corn plantings are affecting habitat and wildlife in the Prairie Pothole Region: Washington, D.C., National Wildlife Federation [a University of Michigan study published by the National Wildlife Federation], $24 \mathrm{p}$. Also available at $h t t p: / / w w w / n w f . o r g / n e w s-a n d-$ magazines/media-center/reports/archive/2010/corn-ethanoland-wildlife.aspx, accessed May 28, 2013.

Cantrell, R., Burkhart-Kriesel, C., Johnson, B., Narjes, C., and Vogt, R., 2008, Moving to the rural Great Plains-Point of origin differences in the decision-making process: Great Plains Research, v. 18, p. 155-163.

Carmichael, D.B., Jr., 1997, The Conservation Reserve Program and wildlife habitat in the southeastern United States: Wildlife Society Bulletin, v. 25, p. 773-775.

Carver, E., and Caudill, J., 2007, Banking on nature 2006The economic benefits to local communities of National Wildlife Refuge visitation: Washington, D.C., U.S. Fish and Wildlife Service Division of Economics, $372 \mathrm{p}$.

Casey, D., Forman, K.J., Granfors, D.A., Johnson, R.R., Lively, C.A., Naugle, D.E., Niemuth, N.D., Reynolds, R.E., and Ringelman, J.K., 2005, Prairie Pothole Joint Venture Implementation Plan Section I-Plan foundation: Denver, Colo., U.S. Fish and Wildlife Service, Prairie Pothole Joint Venture, $21 \mathrm{p}$.

Center for Rural Affairs, 2012, Center for Rural Affairs 2012 Farm Bill Platform, unpaginated. Available at http://www.cfra.org/2012-farm-bill-platform\#conserv, accessed August 8, 2012.

Chan, A.S.K., and Parkin, T.B, 2001, Effect of land use on methane flux from soil: Journal of Environmental Quality, v. 30 , no. 3, p. $786-797$. 
Chi, G., and Marcouiller, D.W., 2011, Isolating the effect of natural amenities on population change at the local level: Regional Studies, v. 45, no. 4, p. 491-505.

Chichilnisky, G., and Heal, G., 1998, Economic returns from the biosphere: Nature, v. 391, p. 629-630.

Cochrane, W.W., 1993, The development of American agriculture-A historical analysis: Minneapolis, Minn., University of Minnesota Press, 520 p.

Coleman, J.S., 1988, Social capital in the creation of human capital: American Journal of Sociology, v. 94, p. S95-S120.

Conger, R.D., and Elder, G.H., Jr., 1994, Families in troubled times-Adapting to change in rural America: New York, Walter de Gruyter, Inc., 303 p.

Coon, R.C., and Leistritz, F.L., 2002, Threshold population levels for rural retail businesses in North Dakota, 2000: Fargo, North Dakota University Department of Agribusiness and Applied Economics, Agricultural Experiment Station, Agribusiness and Applied Economics Miscellaneous Report, no. 191, 10 p.

Cowardin, L.M., Carter, V., Golet, F.C, and LaRoe, E.T., 1979, Classification of wetlands and deepwater habitats of the United States: U.S. Fish and Wildlife Service Report FWS/OBS-79/31, 131 p.

Cromartie, J.B., 1998, Net migration in the Great Plains increasingly linked to natural amenities and suburbanization: Rural Development Perspectives, v. 13, no. 1, p. 27-34.

Dahl, T.E., and Allord, G.J., 1997, Technical aspects of wetlands - History of wetlands in the conterminous United States: U.S. Geological Survey National Water Summary on Wetland Resources, Water Supply Report 2425, unpaginated. Available at http://water.usgs.gov/nwsum/WSP2425/ history.html, accessed March 23, 2013.

Dahlgren, R.B., and Linder, R.L., 1967, Pheasant ups and downs: Pierre, S. Dak., South Dakota Department of Game, Fish and Parks Division of Wildlife, Report No. 109-W, $33 \mathrm{p}$.

Daily, G.C., 1997, Nature's services-Societal dependence on natural ecosystems: Washington, D.C.: Island Press, 392 p.

Dearien, C., Rudzitis, G., and Hintz, J., 2005, The role of wilderness and public land amenities in explaining migration and rural development in the American Northwest, in Green, G.P., Deller, S.C., and Marcouiller, D.W., eds., Amenities and rural development - Theory, methods, and public policy: Cheltenham, U.K. and Northampton, Mass., Elgar Publishing, New Horizons in Environmental Economics series, p. 113-128.
Deller, S.C., Tsai, T., Marcouiller, D.W., and English, D.B., 2001, The role of amenities and quality of life in rural economic growth: American Journal of Agricultural Economics, v. 83, no. 2, p. 352-365.

Deller, S.C., Gould, B.W., and Jones, B., 2003, Agriculture and rural economic growth: Journal of Agricultural and Applied Economics, v. 35, no. 3, p. 517-527.

Deller, S.C., Marcouiller, D.W., English, D.B.K., and Lledo, V., 2005, Regional economic growth with a focus on amenities, in Green, G.P., Deller, S.C., and Marcouiller, D.W., eds., Amenities and rural development-Theory, methods, and public policy: Cheltenham, U.K. and Northampton, Mass., Elgar Publishing, New Horizons in Environmental Economics series, p. 129-152.

Deller, S.C., and Williams, D., 2011, The economic impacts of agriculture in Wisconsin counties: Madison, University of Wisconsin Cooperative Extension, 27 p.

DeVore, B., 2012, Everyone's Farm Bill: St. Paul, Minnesota Department of Natural Resources, Minnesota Conservation Volunteer Magazine [online version], September-October, unpaginated. Available at $h t t p: / / w w w . d n r . s t a t e . m n . u s /$ volunteer/sepoct12/farm_bill.html, accessed March 23, 2013.

Dexter, M., 2010, 2010 Small-game hunter mail survey: St. Paul, Minn, Minnesota Department of Natural Resources Division of Fish and Wildlife, Wildlife Research Unit, 12 p.

Dimitri, C., Effland, A. and Conklin, N., 2005, The 20th century transformation of U.S. agriculture and farm policy: Washington D.C., U.S. Department of Agriculture Economic Research Service, Economic Information Bulletin, no. 3, June 2005, $14 \mathrm{p}$.

Dokken, B., 2011, CRP [Conservation Reserve Program] and wildlife - Where has it all gone?: Agweek, online article, published December 11, 2011, unpaginated. Available at $h t t p: / /$ www.agweek.com/event/article/id/223517/publisher_ID/40/, accessed March 3, 2012.

Domon, G., 2011, Landscape as resource-Consequences, challenges and opportunities for rural development: Landscape and Urban Planning, v. 100, p. 338-340.

Drabenstott, M., 2000, Beyond agriculture-New policies for rural America, a conference summary: Kansas City, Federal Reserve Bank of Kansas City, 5 p. Available at http://www.kc.frb.org.

Drabenstott, M., 2001, New policies for a new rural America: International Regional Science Review, v. 24, no. 1, p. $3-15$.

Drabenstott, M., 2003, A new era for rural policy: testimony before U.S. Congress House Committee on Small Business, September 4, 2003, Federal Reserve Bank of Kansas City, p. $81-98$. 
Duebbert, H.F., 2003, Wildfowling in Dakota, 1873-1903 (1st ed.): Bismark, N. Dak., Windfeather Press, 352 p.

Duffy-Deno, K.T., 1997, The effect of state parks on the county economies of the West: Journal of Leisure Research, v. 29, no. 2, p. 201-224.

Duffy-Deno, K.T., 1998, The effect of federal wilderness on county growth in the intermountain western United States: Journal of Regional Science, v. 38, no. 1, p. 109-136.

Eggebo, S.L., Higgins, K.F., Naugle, D.E., and Quamen, F.R., 2002, Effects of CRP [Conservation Reserve Program] field age and cover type on ring-necked pheasants in eastern South Dakota: Wildlife Society Bulletin, v. 31, no. 3, p. 779-785.

Eichman, H., Hunt, G.L., Kerkvliet, J., and Plantinga, A.J., 2010, Local employment growth, migration, and public land policy-Evidence from the Northwest Forest Plan: Journal of Agricultural and Resource Economics, v. 35, no. 2, p. 316-333.

Endicott, E., ed., 1993, Land conservation through public/private partnerships: Washington, D.C., Island Press, 377 p.

Erickson, R.E., and Wiebe, J.E., 1973, Pheasants, economics and land retirement programs in South Dakota: Wildlife Society Bulletin, v. 1, no. 1, p. 22-27.

Euliss, N.H., Jr., Gleason, R.A., Olness, A., McDougal, R.L., Murkin, H.R., Robarts, R.D., Bourbonniere, R.A., and Warner, B.G., 2006, North American prairie wetlands are important nonforested land-based carbon storage sites: The Science of the Total Environment, v. 361, p. 179-188.

Farlex Financial Dictionary, 2012, Farlex, Inc. , unpaginated. Available at http://financial-dictionary.thefreedictionary. com, accessed January 17, 2012.

Flores, D.L., 1996, A long love affair with an uncommon country-Environmental history and the Great Plains, in Samson, F.B., and Knopf, F.L. eds., Prairie conservationPreserving North America's most endangered ecosystem: Washington, D.C., Island Press, p. 3-17.

Fernandez-Cornejo, J., 2007, Off-farm income, technology adoption, and farm economic performance: U.S. Department of Agriculture Economic Research Service, Economic Research Report series, no. 36, 40 p.

Follett, R.F., Pruessner, E.G., Samson-Liebig, S.E., Kimble, J.M. and Waltman, S.W., 2001, Carbon sequestration under the Conservation Reserve Program in the historic grassland soils of the United States of America, in Lal, R., ed., Carbon Sequestration and Greenhouse Effect: Soil Science Society of America Special Publication, no. 57, p. 27-40.

Freese, C., Montanye, D., and Dabrowska, K., 2009, New directions for the prairie economy - Connecting conservation and rural development in the northern Great Plains: World Wildlife Fund, 57 p.
Fry, J.A., Xian, George, Jin, Suming, Dewitz, J.A., Homer, C.G., Yang, Limin, Barnes, C.A., Herold, N.D., and Wickham, J.D., 2011, Completion of the 2006 National Land Cover Database for the conterminous United States: Photogrammetric Engineering and Remote Sensing, v. 77, no. 9 , p. 858-864.

Gardner, B. L., 2005, The little guys are O.K.: The New York Times, OP-ED section, Monday, March 7, 2005, p. A21-A22.

Gigliotti, L.M., 2009, Hunter evaluation of the 2009 Walk-In Areas report: Pierre, S. Dak., South Dakota Game, Fish and Parks Wildlife Division, Report ID number HD-7-10. AMS, 246 p. Available at http://gfp.sd.gov/hunting/areas/, accessed May 29, 2013.

Gigliotti, L.M., 2010, East and West River deer hunter survey report: Pierre, S. Dak., South Dakota Game, Fish and Parks Wildlife Division, Report ID number HD-8-11.AMS, 228 p. Available at http://gfp.sd.gov/hunting/big-game/deer/ default.aspx, accessed May 29, 2013.

Gleason, R.A., and Euliss, N.H., Jr., 1998, Sedimentation of prairie wetlands: Great Plains Research, v. 8, p. 97-112.

Gleason, R.A., Laubhan, M.K., and Euliss, N.H., Jr., 2008, Ecosystem services derived from wetland conservation practices in the United States Prairie Pothole Region with an emphasis on the U.S. Department of Agriculture Conservation Reserve and Wetland Reserve Programs: U.S. Geological Survey Professional Paper 1745, 58 p.

Goe, W.R, and Green, G.P., 2005, Amenities and change in the well-being of nonmetropolitan localities, in Green, G.P., Deller, S.C., and Marcouiller, D.W., eds., Amenities and Rural Development-Theory, Methods, and Public Policy: Cheltenham, U.K., and Northampton, Mass., Elgar Publishing, New Horizons in Environmental Economics series, p. 95-112.

Goetz, S.J., and Debertin, D.L., 1996, Rural population decline in the 1980s - Impacts of farm structure and federal farm programs: American Journal of Agricultural Economics, v. 78 , no. 3 , p. $517-529$.

Goldschmidt, W., 1947, As you sow: New York, Harcourt, Brace and Company, $288 \mathrm{p}$.

Gottlieb, P.D., 1994, Amenities as an economic development tool-Is there enough evidence?: Economic Development Quarterly, v. 8, no. 3, p. 270-285.

Gray, L.C., Baker, O.E., Marschner, F.J., Weitz, B.O., Chapline, W.R., Shepard, W., and Zon, R., 1924, The utilization of our lands for crops, pasture, and forests, in Yearbook of the Department of Agriculture-1923: Washington, D.C., United States Department of Agriculture, p. 415-506. 
Greenwood, R.J., Sargeant, A.B., Johnson, D.H., Cowardin, L.M., and Shaffer, T.L., 1995, Factors associated with duck nest success in the Prairie Pothole Region of Canada: Wildlife Monographs, v. 128, 57 p.

Grigsby, W.J., 2001, Community vitality-Some conceptual considerations: Pennsylvania State University Northeast Regional Center for Rural Development, Rural Development Report, no. 6, 16 p.

Grovenburg, T.W., Klaver, R.W., and Jenks, J.A., 2012a, Survival of white-tailed deer fawns in the grasslands of the northern Great Plains: Journal of Wildlife Management, v. 76 , no. 5 , p. $944-956$.

Grovenburg, T.W., Klaver, R.W., and Jenks, J.A., 2012b, Spatial ecology of white-tailed deer fawns in the northern Great Plains-Implications of loss of Conservation Reserve Program grasslands: Journal of Wildlife Management, v. 76, no. 3, p. 632-644.

Hansen, L., and Ribaudo, M., 2008, Economic measures of soil conservation benefits-Regional values for policy assessment: U.S. Department of Agriculture Economic Research Service, Technical Bulletin 1922, 25 p.

Harris, J.M., Erickson, K., Dillard, J., Morehart, M., Strickland, R., Gibbs, R., Ahearn, M., Covey, T., Bagi, F., Brown, D., McGath, C., Vogel, S., Williams, B., and Johnson, J., 2008, Agricultural income and finance outlook: U.S. Department of Agriculture Economic Research Service, Report AIS-86, December 2008, 74 p.

Hellerstein, D., and Malcolm, S., 2011, The influence of rising commodity prices on the Conservation Reserve Program: U.S. Department of Agriculture Economic Research Service, Economic Research Report 110, February 2011, 38 p.

Henderson, J., Gloy, B., and Boehlje, M., 2011, Agriculture's boom-bust cycles-Is this time different?: Kansas City, Federal Reserve Bank of Kansas City Fourth Quarter Economic Review, p. 83-105.

Henderson, J., and Akers, M., 2012, Farm lending rises with capital spending and farmland investments: Federal Reserve Bank of Kansas City Agricultural Finance Databook, National Trends in Farm Lending, 4 p.

Herman, G., and Johnson, L., 2008, Habitats of North Dakota-Prairie: Fargo, N. Dak., North Dakota Center for Distance Education, North Dakota Studies Project, ISBN 978-0-9801993-1-4, 66 p. Also available at http://www.ndstudies.org/pdf/prairie_web.pdf, accessed May 24, 2013.

Hoag, D.L., and Parson, J., 2010, Risk Navigator SRM [Strategic Risk Management]-An applied risk management tool: Journal of Probability and Statistics, v. 2010, 17 p.
Hodur, N.M., Leistritz, F.L., and Bangsund, D.A., 2002, Local socioeconomic impacts of the Conservation Reserve Program: Fargo, N. Dak., North Dakota State University Department of Agribusiness and Applied Economics Report, no. 476,119 p.

Hodur, N.M., Leistritz, F.L., and Wolfe, K., 2004, Characteristics and expenditures of participants in the Potholes and Prairie Birding Festival: Fargo, N. Dak., North Dakota State University Department of Agribusiness and Applied Economics Report, no. 04004, 18 p.

Hodur, N.M., Leistritz, F.L., and Wolfe, K.L., 2008, Developing the nature-based tourism sector in southwestern North Dakota: Great Plains Research, v. 18 (Spring 2008), p. 81-92.

Hoekman, S.T., Mills, L.S., Howerter, D.W., Devries, D.J., and Ball, I.J., 2002, Sensitivity analysis of the life cycle of mid-continent mallards: Journal of Wildlife Management, v. 66, p. $833-900$.

Holeywell, R., 2011, North Dakota's oil boom is a blessing and a curse: Governing Magazine, published August 2011, unpaginated. Available at http://www.governing.com/topics/ energy-env/north-dakotas-oil-boom-blessing-curse.html, accessed June 2, 2012.

Ingwersen, J., 2013, U.S. Northern Plains sees corn boom, aided by ethanol, climate: Reuters, U.S. edition, online article, published March 18, 2013, unpaginated. Available at $h t t p: / / w w w . r e u t e r s . c o m / a r t i c l e / 2013 / 03 / 18 /$ usa-crops-dakotas-idUSL1N0C59UA20130318, accessed May 2, 2013.

Iowa Department of Natural Resources [Iowa DNR], 2010, A review of Iowa's upland game bird populations-Report to the Governor and General Assembly: Iowa Department of Natural Resources, Upland Game Bird Study Advisory Committee report, $35 \mathrm{p}$.

Irwin, E.G., Isserman, A.M., Kilkenny, M., and Partridge, M.D., 2010, A century of research on rural development and regional issues: American Journal of Agricultural Economics, v. 92 , no. 2, p. 522-553.

Isserman, A.M., 2001, The competitive advantages of rural America in the next century: International Regional Science Review, v. 24, p. 35-58.

Isserman, A.M., Feser, E., and Warren, D., 2007, Why some rural communities prosper while others do not: International Regional Science Review, v. 32, no. 3, p. 300-342.

Janssen, L., Klein, N., Taylor, G., Opoku, E., and Holbeck, M., 2008, Conservation Reserve Program in South DakotaMajor findings from 2007 survey of South Dakota CRP respondents: Madison, S. Dak., South Dakota State University, Economics Research Report 2008-1 (July), 42 p. 
Johnson, D.H., and Schwartz, M.D., 1993, The Conservation Reserve Program - Habitat for grassland birds: Great Plains Research, v. 3, p. 273-295.

Johnson, K.M., and Rathge, R.W., 2006, Agricultural dependence and changing population in the Great Plains, in Kandel, W.A., and Brown, D.L., eds., Population change and rural society: Dordrecht, The Netherlands, Springer, 197 p.

Johnson, K.M., and Stewart, S.I., 2007, Demographic trends in national forest, recreational, retirement, and amenity areas, in National Workshop on Recreation Research and Management, Portland, Oreg., Proceedings: Portland, U.S. Department of Agriculture, U.S. Forest Service Pacific Northwest Research Station General Technical Report, PNW-GTR-698, p. 187-199.

Johnson, T.G., 1997, Policy conundrums in rural North America-Discussion: American Journal of Agricultural Economics, v. 79 , no. 5, p. 1527-1529.

Johnson, T.G., 2001, The rural economy in a new century: International Regional Science Review, v. 24, no. 1, p. 21-37.

Johnson, T.G., 2007, Place-based economic policy-Innovation or fad?: Agricultural and Resource Economics Review, v. 36, p. $1-8$.

Kantrud, H.A., 1993, Duck nest success on Conservation Reserve Program land in the Prairie Pothole Region: Journal of Soil and Water Conservation, v. 48, no. 3, p. 238-242.

Kilkenny, M., and Partridge, M.D., 2009, Export sectors and rural development: American Journal of Agricultural Economics, v. 91, no. 4, p. 910-929.

Kirwan, B., 2009, The incidence of U.S. agricultural subsidies on farmland rental rates: Journal of Political Economy, v. 117 , no. 1, p. $138-164$.

Kroeger, T., 2008, Community economic competitive analysis: Defenders of Wildlife National Council for Science and the Environment, Wildlife Habitat Policy Research Program, $35 \mathrm{p}$.

Kulcsár, L.J., and Bolender, B.C., 2011, If you build it, will they come?-Biofuel plants and demographic trends in the Midwest: Population Environment, v. 32, p. 318-331.

Kusnetz, N., 2012, Bakken oil play spurs booming business in water: The Montana Pioneer, High Country News, online article, unpaginated. Available at http://www.mtpioneer.com, accessed November 2012.

Kwang-Koo, K., Marcouiller, D.W., and Deller, S.C., 2005, Natural amenities and rural development-Understanding spatial and distributional attributes: Growth and Change, v. 36 , no. 2 , p. 273-297.
Leier, D., 2009, The importance of CRP [Conservation Reserve Program]: Nordak Outdoors, February 15, 2009, online article. Available at http://www.nodakoutdoors.com/ valleyoutdoors20.php, accessed January 2012.

Leitch, J.A., and Baltezore, J.F., 1993, The hunt for economic development: Fargo, N. Dak., North Dakota State University, North Dakota Farm Research Articles, p. 13-17.

Leitch, J.A., Baltezore, J.F., and Dammel, J., 1993, Economic values of wild fur harvest in North Dakota: Fargo, N. Dak., North Dakota State University Department of Agricultural Economics, Agricultural Economics Miscellaneous Report, no. $170,22 \mathrm{p}$.

Levins, R.A., 2000, Willard Cochrane and the American Family Farm: Lincoln, Neb., University of Nebraska Press, 88 p.

Lewis, D.J., Hunt, G.L., and Plantinga, A.J., 2002, Public conservation land and employment growth in the northern forest region: Land Economics, v. 78, no. 2, p. 245-259.

Lobao, L.M., 1990, Locality and inequality—Farm and industry structure and socioeconomic conditions: Albany, N.Y., State of New York Press, 291 p.

Lobao, L.M., and Stofferahn, C.W., 2007, The community effects of industrialized farming-Social science research and challenges to corporate farming laws: Agriculture and Human Values, v. 25, p. 219-240.

Malizia, E.E., and Ke, S., 1993, The influence of economic diversity on unemployment and stability: Journal of Regional Science, v. 33, no. 2, p. 221-235.

Manale, A., 2000, Flood and water-quality management through targeted, temporary restoration of landscape function-Paying upland farmers to control runoff: Journal of Soil and Water Conservation, v. 55, p. 285-295.

Marousek, G., 1979, Farm size and rural communities-Some economic relationships: Southern Journal of Agricultural Economics, v. 11, p. 57-61.

Martin, M., Radtke, H., Eleveld, B., and Nofziger, S.D., The Impacts of the Conservation Reserve Program on Rural Communities-The case of three Oregon counties: Western Journal of Agricultural Economics, v. 13, no. 2, p. 225-232.

Mason, J., 2012, Bakken's maximum potential oil production rate explored: Oil and Gas Journal, published April 2, 2012, unpaginated. Available at $h t t p: / / w w w . o g j . c o m$, accessed February 2012.

McGranahan, D., 1999, Natural amenities drive rural population change: Washington, D.C., U.S. Department of Agriculture Economic Research Service, report AER-781, 27 p.

McGranahan, D., 2008, Landscape influence on recent rural migration in the U.S: Landscape and Urban Planning, v. 85, p. 228-240. 
McGranahan, D., Cromartie, J., and Wojan, T., 2010, The two faces of rural population loss through outmigration: U.S Department of Agriculture Economic Research Service, Amber Waves, v. 8, issue 4 [December 2010], p. 38-45.

McGranahan, D., and Sullivan, P., 2005, Farm programs, natural amenities, and rural development: U.S Department of Agriculture Economic Research Service, Amber Waves, v. 3, issue 1 [February 2005], p. 28-35.

Merbach, W., Kalettka, T., Rudat, C., and Augustin, J., 2002, Trace gas emissions from ripariran areas of small eutrophic inland waters in northeast Germany, in Broll, G., Merbach, W. and Pfeiffer, E.V., eds., Wetlands in central EuropeSoil organisms, soil ecological processes, and trace gas emission: Berlin, Springer, p. 235-244.

Miao, R., Hennessy, D.A., and Feng, H., 2012, The effects of crop insurance subsidies and sodsaver on land-use change: Ames, Iowa, Iowa State University Center for Agricultural and Rural Development, Working Report 12-WP 530, 16 p.

MIG, Inc. [formerly Minnesota Implan Group, Inc.], 2009, IMPLAN System Year 2009 county-level data and v. 3 software, 1725 Tower Drive West, Suite 140, Stillwater, MN. 55082 , unpaginated. Also available at www.implan.com, last accessed April 20, 2012.

Millennium Ecosystem Assessment [MEA], 2003, Ecosystems and human well-being-A framework for assessment: Washington, D.C: Island Press, 245 p.

Miller, K.K., and Rowley, T.D., 2002, Rural poverty and rural-urban income gaps-A troubling snapshot of the "prosperous" 1990s: Columbia, Mo., Rural Policy Research Institute [RUPRI], Data Report P2002-5, 12 p.

Minnesota Geological Survey, 2011, Minnesota's remaining native prairie-A century after the public land survey: St. Paul, Minn., Minnesota Department of Natural Resources, unpaginated. GIS map available at http://files.dnr.state.mn.us/ eco/mcbs/prairie_map.pdf, accessed June 7, 2012.

Minnesota Department of Natural Resources [Minn. DNR], 2010, 2010 Minnesota deer harvest report: St. Paul, Minn., Minnesota Department of Natural Resources Division of Fish and Wildlife, unpaginated.

Mitchell, M.D., and Kimmel, R.O., 2009, Landowner attitudes and perceptions regarding wildlife benefits of the Conservation Reserve Program: Rural Minnesota Journal, The Agriculture and Forestry Issue-Looking to the Future., v. 4, p. 93-106.

Monchuk, D.C., Miranowski, J.A., Hayes, D.J., and Babcock, B.A., 2005, An analysis of regional economic growth in the U.S. Midwest: Review of Agricultural Economics, v. 29, no. 1, p. 17-39.
Mortensen, T.L., Leistritz, F.L., Leitch, J.A., Coon, R.C., and Ekstrom, B.L., 1989, Landowner characteristics and the economic impact of the Conservation Reserve Program in North Dakota: Journal of Soil and Water Conservation, v. 44 , no. 5 , p. $494-497$.

Mosier, A., Schimel, D., Valentine, D., Bronson, K., and Parton, W., 1991, Methane and nitrous oxide fluxes in native, fertilized, and cultivated grasslands: Nature, v. 350, p. 330-332.

Muir, P., 2008, The Conservation Reserve Program: Corvallis, Oreg., Oregon State University Department of Education, unpaginated. Available at http://people.oregonstate.edu/ muirp/crp.htm, accessed November 27, 2011.

Nielson, R.M., McDonald, L.L., Howlin, S., Sullivan, J.P., Burgess, C., and Johnson, D.S., 2006, Estimating response of ring-necked pheasant (Phasianus colchicus) to the Conservation Reserve Program: Washington, D.C., U.S. Department of Agriculture Farm Service Agency, report prepared under Contract Number 53-3151-5-8059, 51 p.

Niemuth, N.D., Quaman, F.R., Naugle, D.E., Reynolds, R.E., Estey, M.E., and Shaffer, T.L., 2007, Benefits of the Conservation Reserve Program to grassland bird populations in the Prairie Pothole Region of North Dakota and South Dakota: Washington, D.C., U.S. Department of Agriculture Farm Service Agency, report prepared under Contract Number RFA OS-IA-04000000-N34, 49 p.

North, D., 1959, Agriculture in regional economic growth: Journal of Farm Economics, v. 41, no. 5, p. 943-951.

North Dakota Court System, 2011, Annual Report: Bismarck, N. Dak., North Dakota Supreme Court, released May 2, 2012, 31 p. Available at http://www.ndcourts.gov/court/ annual.htm, accessed May 29, 2013.

North Dakota Department of Commerce, 2011, North Dakota tourism 2011 annual report-I am legendary! RU?: Bismarck, N. Dak., North Dakota Department of Commerce Tourism Division, 20 p. Available at http://www.ndtourism.com/search/ site/2011\%2520tourism\%2520report, accessed June 5, 2013.

North Dakota Industrial Commission, 2013, Drilling and Production Statistics: Bismarck, North Dakota Department of Mineral Resources, Oil and Gas Division, unpaginated. Available at www.dmr.nd.gov, accessed May 23, 2013.

North Dakota State Game and Fish Department, 2010, Study No. B-I-Pheasant population data-2003 Pheasant Harvest Data: Bismarck, North Dakota State Game and Fish Department Report, no. C-282, submitted by Kohn, S.C., Project W-67-R-44, Phase B of Upland Game Investigations, submitted March 2010, unpaginated.

North Dakota State Game and Fish Department, 2011a, Study No. B-I-Pheasant population data-2010 Pheasant Harvest Data: Bismarck, North Dakota State Game and Fish Department Report, no. C-282, submitted by Kohn, S.C., Project W-68-R-51, Phase B of Upland Game Investigations, submitted June 2011, unpaginated. 
North Dakota State Game and Fish Department, 2011b, Study No. C-I-Deer Population Studies - Deer Harvest Data: Bismarck, North Dakota State Game and Fish Department Report, no. A-194, submitted by Johnson, R., Jensen, B. and Stillings, B., Project W-67-R-51, Phase C of Upland Game Investigations, submitted July 2011, 123 p.

North Dakota State Game and Fish Department, 2011c, Study No. D-I-Waterfowl Population Study - 2010 Waterfowl Harvest Data: Bismarck, North Dakota State Game and Fish Department Report, no. A-740, submitted by Johnson, M.A., Project W-67-R-51, Phase D of Migratory Game Bird Investigations, submitted December 2011, 57 p.

Nowatzki, M., 2012, Oil patch crime rates skyrocket: Grand Forks, No. Dak., Grand Forks Herald, published May 4, 2012. Available at http://www.grandforksherald.com, accessed June 11, 2012, unpaginated.

Olsen, D., and Schmidt, H., 2011, As corn acreage increases, so does economic impact on region: INFORUM News Article, published October 24, 2011. Available at http://www.inforum.com/event/article/id/338243/, accessed February 18, 2012, unpaginated.

Otto, D., Monchuk, D., Jintanakul, K., and Kling, C., 2007, The economic value of Iowa's natural resources: Ames, Iowa State University of Science and Technology Department of Economics Staff Paper [December 2007], 46 p.

Power, T.M., and Barrett, R.N., 2001, Post-cowboy economics-Pay and prosperity in the American West: Washington, D.C., Island Press, 185 p.

Pulver, G.C., and Rogers, G.R., 1986, Changes in income sources in rural America: American Journal of Agricultural Economics, v. 68, no. 5, p. 1181-1187.

Rashford, B.S., Walker, J.A., and Bastian, C.T., 2010, Economics of grassland conversion to cropland in the Prairie Pothole Region: Conservation Biology, v. 25, no. 2, p. 276-284.

Responsive Management, 2002, Minnesota deer hunter's opinions and attitudes toward deer management: Harrisonburg, Virginia, Responsive Management [survey conducted for Minnesota Department of Natural Resources], 252 p.

Reynolds, R.E., Shaffer, T.L., Renner, R.W., Newton, W.E., and Batt, B.D.J., 2001, Impact of the Conservation Reserve Program on duck recruitment in the U.S. Prairie Pothole Region: Journal of Wildlife Management, v. 65, no. 4, p. 765-780.

Reynolds, R.E., Shaffer, T.L., Loesch, C.R., and Cox, R.R., Jr., 2006, The Farm Bill and duck production in the Prairie Pothole Region-Increasing the benefits: Wildlife Society Bulletin, v. 33, no. 4, p. 963-974.
Reynolds, R.E, Loesch, C.R., Wangler, B., and Shaffer, T.L., 2007, Waterfowl response to the Conservation Reserve Program and Swampbuster provision in the Prairie Pothole Region, 1992-2004: U.S. Fish and Wildlife Service and U.S. Department of Agriculture Farm Service Agency, report prepared under contract RFA 05-IA-04000000-N34, $50 \mathrm{p}$.

Riley, T.Z., 1995, Association of the Conservation Reserve Program with ring-necked pheasant survey counts in Iowa: Wildlife Society Bulletin, v. 23, p. 386-390.

Rudzitis, G., 1996, Wilderness and the changing American West: New York, John Wiley and Sons, 220 p.

Rudzitis, G., and Johansen, H.E., 1989, Migration to wilderness counties in the West: Western Wildlands, v. 15, p. 19-23.

Rudzitis, G., and Johansen, H.E., 1991, How important is wilderness?-Results from a United States survey: Environmental Management, v. 15, no. 2, p. 227-233.

Rudzitis, G., and Johnson, R., 2000, The impact of wilderness and other wildlands on local economies and regional development trends: Fort Collins, Colo., U.S. Department of Agriculture Forest Service, Rocky Mountain Research Station, Proceedings RMRS-P-15-VOL-2, p. 14-26.

Rural Community Assistance Corporation [RCAC], 2011, Rural Colorado town struggles to survive despite population losses: Rural Community Assistance Corporation, unpaginated, published March 8, 2011. Available at http://www.rcac.org, accessed June 17, 2012.

Ryan, R., 2007, Live first, work second-Getting inside the head of the next generation: Madison, Wis., Next Generation Consulting, $118 \mathrm{p}$.

Samson, F.B., and Knopf, F.L., eds., 1996, Prairie conservation-Preserving North America's most endangered ecosystem: Washington, D.C., Island Press, 339 p.

Schroeder, S., Fulton, D.C., Lawrence, J.S., and Cordts, S.D., 2007, Waterfowl hunting in Minnesota-A follow-up study of respondents to the 2001 waterfowl survey: St. Paul, Minn., University of Minnesota Department of Fisheries, Wildlife, and Conservation Biology, Minnesota Cooperative Fish and Wildlife Research Unit, 152 p.

Simon, H.A., 1947, Effects of increased productivity upon the ratio of urban to rural populations: Econometrica, v. 15, p. $31-42$.

Sjaastad, L.A., 1962, The cost and returns of human migration: Journal of Political Economy, v. 705, p. 80-93.

Smith, D.D., 1998, Iowa prairie-Original extent and loss, preservation and recovery attempts: Journal of Iowa Academy of Science, v. 105, no. 3, p. 94-108. 
South Dakota Department of Game Fish and Parks, 2010a, Big game harvest reports-Archery deer: South Dakota Department of Game, Fish, and Parks, 3 p. Available at http://gfp.sd.gov/hunting/harvest/default.aspx, accessed February 7, 2012.

South Dakota Department of Game Fish and Parks, 2010b, Big game harvest reports-East River firearm deer: South Dakota Game Fish and Parks, 7 p. Available at http://gfp.sd.gov/hunting/harvest/default.aspx, accessed February 7, 2012.

South Dakota Department of Game Fish and Parks, 2010c, Big game harvest reports-Muzzleloader deer: South Dakota Game Fish and Parks, 3 p. Available at $h t t p: / / g f p . s d . g o v /$ hunting/harvest/default.aspx, accessed February 7, 2012.

South Dakota Department of Game Fish and Parks, 2010d, Small game harvest reports-Ducks: South Dakota Game Fish and Parks, 4 p. Available at http://gfp.sd.gov/hunting/ harvest/default.aspx, accessed February 7, 2012.

South Dakota Department of Game Fish and Parks, 2010e, Small game harvest reports - Canada Geese (all seasons): South Dakota Game Fish and Parks, 4 p. Available at http://gfp.sd.gov/hunting/harvest/default.aspx, accessed February 7, 2012.

South Dakota Department of Game Fish and Parks, 2010f, Small game harvest reports-Pheasant: South Dakota Game Fish and Parks, 7 p. Available at http://gfp.sd.gov/hunting/ harvest/default.aspx, accessed February 7, 2012.

Stephens, S., Walker, J., Blunck, D., Jayaraman, A.. and Naugle, D., 2006, Grassland conversion in the Missouri Coteau of North and South Dakota, 1984-2003: Ducks Unlimited, Preliminary Report, 14 p.

Strege, S. D., 2009, Comments of North Dakota Grain Dealers Association re Conservation Reserve Program for consideration in draft Environmental Impact Statement: Fargo, N. Dak., North Dakota Grain Dealers Association, email letter submitted October 19, 2009, 4 p. Available at: http:// www.ndgda.org/uploads/1/3/3/1/13312536/crp_meeting_ comments_to_usda.pdf, accessed May 23, 2013.

Stubbs, M., 2007, Land conversion in the Northern Plains: Washington, D.C., U.S. Congressional Research Service Report for Congress, Resources, Science, and Industry Division, Order Code RL33950, April 5, 2007, 12 p.

Sullivan, P., Hellerstein, D., Hanson, L., Johansson, R., Koenig, S., Lubowski, R., McBride, W., McGranahan, D., Roberts, M., Vogel, S., and Bucholtz, S., 2004, The Conservation Reserve Program-Economic implications for rural America: U.S. Department of Agriculture Economic Research Service, Agricultural Economic Report, no. 834, $106 \mathrm{p}$.
Swanson, D.A., Scott, D.P., and Risley, D.L., 1999, Wildlife benefits of the Conservation Reserve Program in Ohio: Journal of Soil and Water Conservation, v. 54, p. 390-394.

The Saguaro Seminar, 2000, Better Together-The report of the Saguaro Seminar - Civic engagement in America, 2001: Cambridge, Mass., Harvard University Kennedy School of Government, 79 p. Available at http://www.hks.harvard.edu/ saguaro/socialcapitalprimer.htm, accessed March 4, 2013.

Tiner, R.W. Jr., 1984, Wetlands of the Unites States - Current status and recent trends: Washington, D.C., U.S. Fish and Wildlife Service, $58 \mathrm{p}$.

Urban Institute and Brookings Institution, 2008, State and local tax policy-What are the sources of revenue for local governments?: Washington, D.C., Tax Policy Center. Available at http://www.taxpolicycenter.org/briefing-book/ state-local/revenues/local_revenue.cfm, unpaginated, accessed July 18, 2011.

U.S. Census, 2010, Lists of population, land area, and percent urban and rural in 2010, and changes from 2000 to 2010: Washington, D.C., U.S. Census Bureau, unpaginated. Available at $h t t p: / / w w w . c e n s u s . g o v / g e o / r e f e r e n c e / u a / u r b a n-$ rural-2010.html, accessed May 2, 2013.

U.S. Department of Agriculture Economic Research Service [USDA-ERS], 1995, Understanding rural America: Washington, D.C., U.S. Department of Agriculture Economic Research Service, Agricultural Information Bulletin, no. 710 [updated 1997], $36 \mathrm{p}$.

U.S. Department of Agriculture Economic Research Service [USDA-ERS], 2003, Rural-urban continuum codes. Available at $h t t p: / / w w w . e r s . u s d a . g o v / B r i e f i n g / P o p u l a t i o n / d a t a . h t m$, accessed October 12, 2012.

U.S. Department of Agriculture Economic Research Service [USDA-ERS], 2011a, Historical and state-level dataU.S. farm income and wealth statistics-Net cash income, 1910-2011: Washington, D.C., U.S. Department of Agriculture Economic Research Service, unpaginated. Available at http://www.ers.usda.gov/data-products/farm-income-andwealth-statistics.aspx, accessed October 25, 2012.

U.S. Department of Agriculture Economic Research Service [USDA-ERS, 2011b, Atlas of rural and small-town America-Jobs, unemployment rate, outmigration patterns: Washington, D.C., U.S. Department of Agriculture Economic Research Service. Available at $h t t p: / / w w w . e r s . u s d a . g o v /$ data-products/atlas-of-rural-and-small-town-america.aspx, accessed April 3, 2012.

U.S. Department of Agriculture Economic Research Service [USDA-ERS], 2012, State fact sheets: Washington, D.C., U.S. Department of Agriculture Economic Research Service. Available at $h t t p: / / w w w . e r s . u s d a . g o v / d a t a-p r o d u c t s /$ state-fact-sheets.aspx, accessed May 20, 2013. 
U.S. Department of Agriculture Farm Service Agency [USDAFSA], 2011, Conservation Reserve Program contract expirations by state, 2011-2017: Washington, D.C., U.S. Department of Agriculture Farm Services Agency. Available at http://www.fsa.usda.gov/FSA/webapp? area $=$ home\&subject $=$ copr\&topic=rns-css, accessed May 20, 2013.

U.S. Department of Agriculture Farm Service Agency [USDA-FSA], 2012, Conservation Reserve Program enrollment and rental payments by state, 1986-2011: Washington, D.C., U.S. Department of Agriculture Farm Service Agency, Conservation Reserve Program Statistics. Available at http://www.fsa.usda.gov, accessed May 20, 2013.

U.S. Department of Agriculture National Agricultural Statistics Service [USDA-NASS], 2011, Statistics by state-State agricultural overview: Washington, D.C., U.S. Department of Agriculture National Agricultural Statistics Service. Accessed for North Dakota, South Dakota, Minnesota, and Iowa. Available at $h t t p: / / w w w . n a s s . u s d a . g o v /$ Statistics_by_State, accessed May 20, 2013.

U.S. Department of Agriculture National Agricultural Statistics Service, North Dakota Office [USDA-NASS, ND], 2011, North Dakota county rents and values-Land values and farm numbers: Washington, D.C., U.S. Department of Agriculture National Agricultural Statistics Service. Available at http://www.nass.usda.gov/Statistics_by_State/North_Dakotal Publications/Land_Values_and_Farm_Numbers/index.asp, accessed May 20, 2013.

U.S. Department of Agriculture National Agricultural Statistics Service [USDA-NASS], 2012, USDA expects 75-yearhigh corn acreage in 2012: Washington, D.C., U.S. Department of Agriculture National Agricultural Statistics Service, newsroom release, March 30, 2012, unpaginated. Available at http://www.nass.usda.gov/Newsroom/2012, accessed May 20, 2013.

U.S. Department of Commerce Bureau of Economic Analysis [USDC-BEA], 2008, Gross domestic product by stateRegional data: Washington, D.C., U.S. Department of Commerce Bureau of Economic Analysis, unpaginated. Available at $h t t p: / / w w w . b e a . g o v /$ regional/, accessed May 20, 2013.

U.S. Department of Commerce Bureau of Economic Analysis [USDC-BEA], 2010, Annual state and local area personal income and employment — Regional data: Washington, D.C., U.S. Department of Commerce Bureau of Economic Analysis, unpaginated. Available at $h t t p: / / w w w . b e a . g o v /$ regional/, accessed May 20, 2013.
U.S. Department of Labor Bureau of Labor Statistics [USDLBLS], 2012, Consumer product index [CPI] inflation calculator: Washington, D.C., U.S. Department of Labor Bureau of Labor Statistics, unpaginated. Available at http://www.bls.gov/data/inflation_calculator.htm, accessed May 20, 2013.

U.S. Environmental Protection Agency [EPA], 2003, Inventory of U.S. greenhouse gas emission and sinks1990-2001: Washington, D.C., U.S. Environmental Protection Agency, 596 p.

U.S. Government Accountability Office [GAO], 2007, Prairie Pothole Region-At the current pace of acquisitions, the U.S. Fish and Wildlife Service is unlikely to achieve its habitat protection goals for migratory birds: U.S. Government Accountability Office Report to the Subcommittee on Interior, Environment, and Related Agencies, Committee on Appropriations, House of Representatives, United States Congress, report GAP-07-1093, 49 p.

U.S Government Interagency Working Group on Social Cost of Carbon, 2010, Social cost of carbon for regulatory impact analysis: U.S. Government Interagency Working Group on Social Cost of Carbon, Technical Support Document [prepared under Executive Order 12866], $50 \mathrm{p}$.

Van der Sluis, E., and Peterson, W.L., 1994, Do cropland diversion programs harm rural communities?: St. Paul, University of Minnesota, Minnesota Extension Service, Minnesota Agricultural Economics Report, no. 677, 21 p.

Wagner, J.E, and Deller, S.C., 1998, Measuring the effects of economic diversity on growth and sustainability: Land Economics, v. 74, no. 4, p. 541-556.

Walzer, N., and Deller, S.C., 1996, Rural issues and trendsRole of strategic visioning programs, in Walzer, N., ed., Community strategic visioning programs: Westport, Conn., Praeger Press, $248 \mathrm{p}$.

White, K.C., 2008, Population change and farm dependenceTemporal and spatial variation in the U.S. Great Plains, 1900-2000: Demography, v. 45, no.2, p. 363-386.

Whitener, L.A., and Parker, T., [updated] 2007, Policy options for a changing rural America: U.S Department of Agriculture Economic Research Service [USDA-ERS], Amber Waves, v. 5 [special issue], p. 58-65. [Originally published as April 2005, v. 3, issue 2.]

Yamanaka, J., 2012, 40 percent of traffic in Williston is semitruck: Transportation Nation [online article], published June 20, 2012. Available at http://transportationnation. org/2012/06/20/40-of-traffic-in-williston-is-semi-truck/, accessed January 11, 2013.

Young, M. 2008, Rescuing the duck factory: Ducks Unlimited Magazine, November-December 2008, p. 70-73. 

Appendixes 



\section{Appendix A}

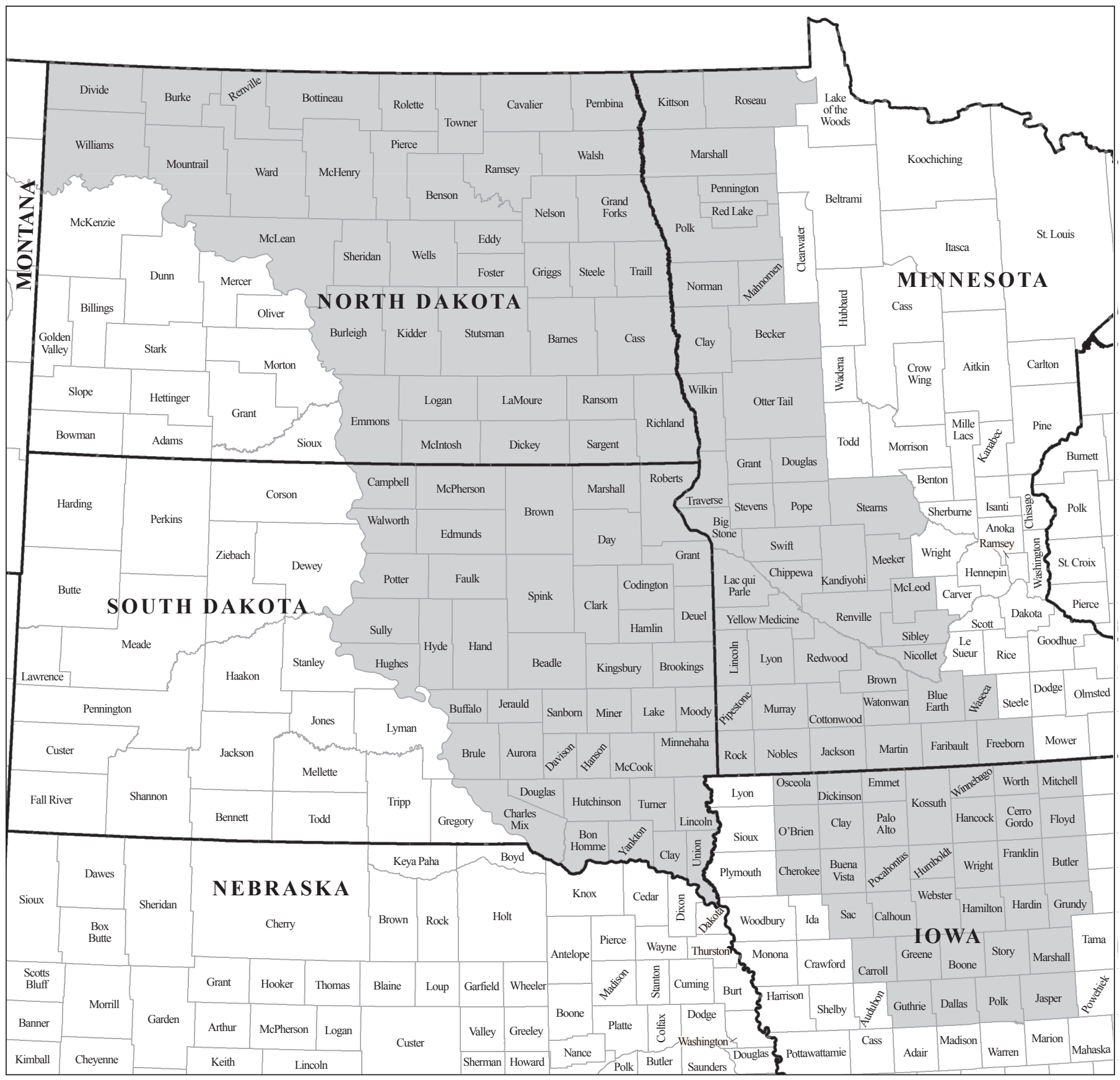

Base from ESRI Data \& Maps DVD 2010

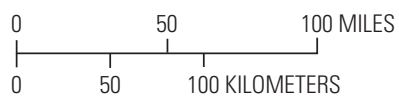

EXPLANATION

Prairie Pothole Region of the United States

Figure A-1. Map of the Prairie Pothole Region of the United States as defined for this report, including county names. 



\section{Appendix B}

This appendix is provided for reference to figure 1-9 in the main text. It gives definitions of land-cover classes used in the 2006 U.S. Fish and Wildlife Service Habitat and Population Evaluation Team (HAPET) land-cover database (Fry and others, 2011) covering the Prairie Pothole Region of the United States as used herein to model perennial habitat acreage. Definitions were obtained from the North Dakota and Minnesota HAPET offices. Minimum acreages for mapped units were 0.22 acres for wetlands, 0.66 acres for tree-covered areas, and 0.22 acres for upland land-cover classes.

Table B-1. Definitions of land-cover classes used in the 2006 U.S. Fish and Wildlife Service Habitat and Population Evaluation Team (HAPET) land-cover database (Fry and others, 2011) for the Prairie Pothole Region of the United States.

\begin{tabular}{|c|c|}
\hline Class & Description \\
\hline Undisturbed grass & $\begin{array}{l}\text { Mix of cool-season grass and forb species planted on previously cropped land; generally undisturbed but may be } \\
\text { hayed or grazed intermittently. }\end{array}$ \\
\hline Hay & Mix of alfalfa and cool-season grass species hayed once or twice annually. \\
\hline Temporary wetland & $\begin{array}{l}\text { Wetland basinsa in which surface water is present for brief periods during the growing season but the water table } \\
\text { is otherwise well below the soil surface. }\end{array}$ \\
\hline Seasonal wetland & $\begin{array}{l}\text { Wetland basinsa in which surface water is present for extended periods, especially early in the growing season, } \\
\text { but is absent by the end of the season in most years. }\end{array}$ \\
\hline Semipermanent wetland & $\begin{array}{l}\text { Wetland basinsa in which surface water persists throughout the growing season in most years. When surface water } \\
\text { is absent, the water table is at or near the soil surface. }\end{array}$ \\
\hline
\end{tabular}


Table B-2. Explanations of ownerships and land classifications in conserved- or protected-status lands of the Prairie Pothole Region, United States, including modeling notes in reference to figure 1-9 of this report. See list of abbreviations in front matter for acronyms.

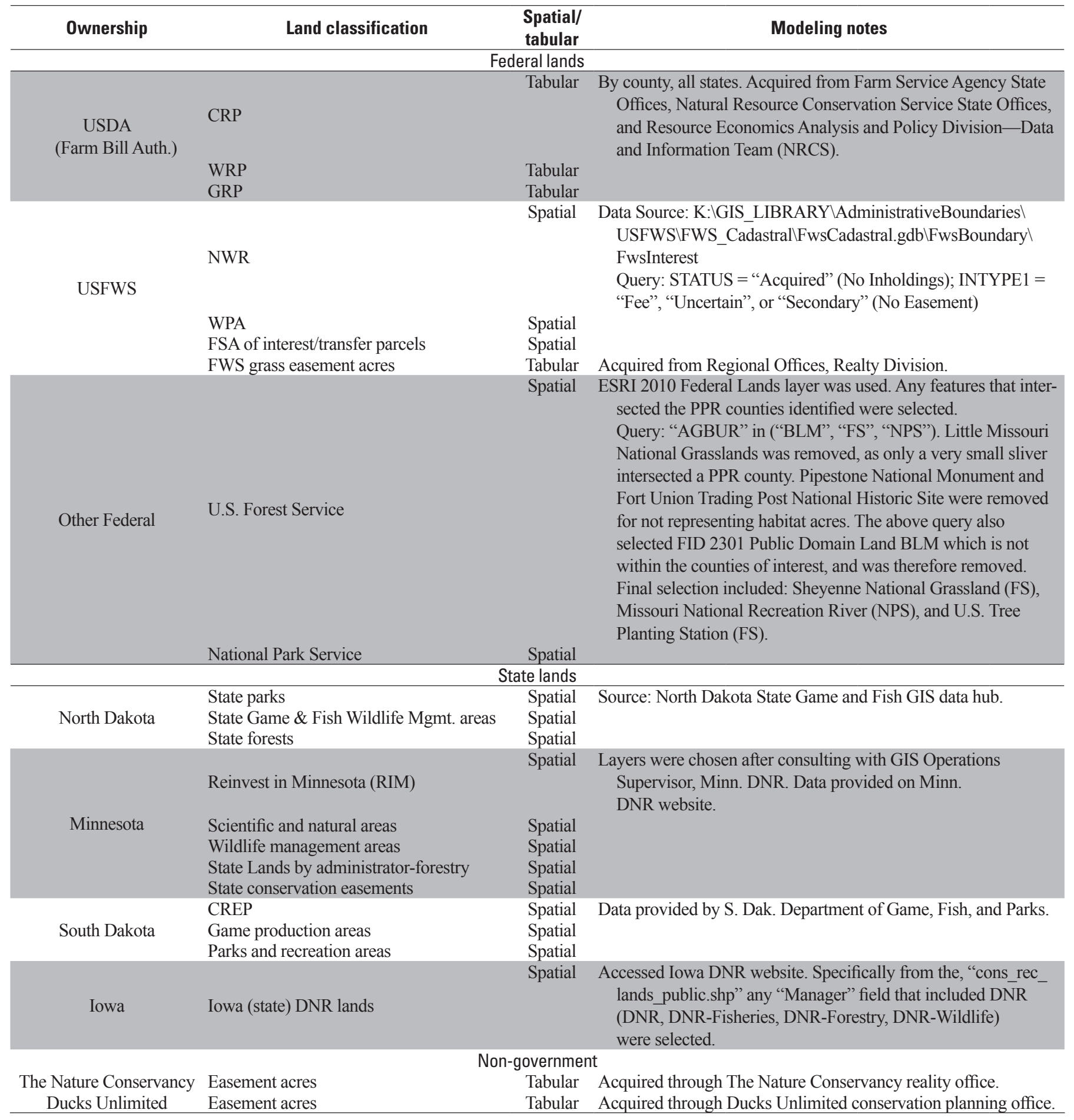




\section{Appendix C}

Sources shown here were used to estimate the economic contribution of hunting (deer, upland, and waterfowl) in the Prairie Pothole Region [including portions of North Dakota (N. Dak.), South Dakota (S. Dak.), Minnesota (Minn.), and Iowa], by county (see listed references for complete source information). Key data categories included the number of hunters per county by license type, the average number of hunting days by license type, and the percentage breakdowns of time hunting on private and/or public lands.

Table C-1. Data sources for economic contributions of hunting in the Prairie Pothole Region of the United States, arranged by state and respective faunal targets.

[Abbreviations: PPR, Prairie Pothole Region; Muzz., muzzle-loading rifle]

\begin{tabular}{lll}
\hline & & \multicolumn{1}{c}{ North Dakota } \\
\hline \multirow{3}{*}{ Number of hunters in N. Dak. PPR } & Rifle & North Dakota State Game and Fish Department (2011b) \\
& Muzz. & North Dakota State Game and Fish Department (2011b) \\
& Rifle & North Dakota State Game and Fish Department (2011b) \\
\multirow{4}{*}{ Average number of hunt days } & Bow & North Dakota State Game and Fish Department (2011b) \\
& Muzz. & North Dakota State Game and Fish Department (2011b) \\
& Rifle & Bangsund and Leistritz (2003) \\
Percent on private vs. public land & Bow & Bangsund and Leistritz (2003) \\
& Muzz. & Bangsund and Leistritz (2003) \\
\hline
\end{tabular}

Pheasants

North Dakota State Game and Fish Department (2010; 2011a); 2011a Report provided total number of resident and nonresident pheasant hunters in N. Dak. in 2010; 2010 survey provided number of

Number of hunters in N. Dak. PPR hunting days by county (from which individual percentages were calculated).

North Dakota State Game and Fish Department (2011a)

Average number of hunt days Bangsund and Leistritz (2003)

Percent on private vs. public land Bangsund and Leistritz (2003)

Waterfowl

Number of hunters in N. Dak. PPR North Dakota State Game and Fish Department (2011c)

Average number of hunt days Bangsund and Leistritz (2003)

Percent on private vs. public land Bangsund and Leistritz (2003)

\begin{tabular}{|c|c|}
\hline \multicolumn{2}{|r|}{ South Dakota } \\
\hline \multicolumn{2}{|r|}{ Deer } \\
\hline Number of hunters in S. Dak. PPR & S. Dak. Department of Game, Fish and Parks (2010a) \\
\hline \multirow{3}{*}{ Average number of hunt days } & Rifle $\quad$ S. Dak. Department of Game, Fish and Parks (2010b) \\
\hline & S. Dak. Department of Game, Fish and Parks (2010a) \\
\hline & Muzz. S. Dak. Department of Game, Fish and Parks (2010c) \\
\hline Percent on private vs. public land & Rifle Gigliotti (2010); used mean values for East River Deer Hunters specifically \\
\hline \multicolumn{2}{|r|}{ Pheasants } \\
\hline \multicolumn{2}{|c|}{ Number of hunters in S. Dak. PPR S. Dak. Department of Game, Fish and Parks (2010f) } \\
\hline Average number of hunt days & S. Dak. Department of Game, Fish and Parks (2010f) \\
\hline Percent on private vs. public land & Gigliotti (2009) \\
\hline \multicolumn{2}{|r|}{ Waterfowl } \\
\hline Number of hunters in S. Dak. PPR & S. Dak. Department of Game, Fish and Parks (2010d) \\
\hline \multicolumn{2}{|r|}{ Minnesota } \\
\hline \multicolumn{2}{|r|}{ Deer } \\
\hline \multirow{3}{*}{ Number of hunters in Minn. PPR } & Minnesota Department of Natural Resources (2010) \\
\hline & Minnesota Department of Natural Resources (2010) \\
\hline & Minnesota Department of Natural Resources (2010) \\
\hline \multirow{3}{*}{ Average number of hunt days } & Responsive Management (2002); used mean estimate \\
\hline & Responsive Management (2002); used mean estimate \\
\hline & Responsive Management (2002); used mean estimate \\
\hline \multirow{3}{*}{ Percent on private vs. public land } & Bangsund and Leistritz (2003) \\
\hline & Bangsund and Leistritz (2003) \\
\hline & Muzz. Bangsund and Leistritz (2003) \\
\hline
\end{tabular}


Table C-1. Data sources for economic contributions of hunting in the Prairie Pothole Region of the United States, arranged by state and respective faunal targets.-Continued

[Abbreviations: PPR, Prairie Pothole Region; Muzz., muzzle-loading rifle]

Minnesota-Continued
Pheasants

\begin{tabular}{ll}
\hline Number of hunters in Minn. PPR & Dexter (2010); data summations by Minn. Department of Natural Resources biometrician \\
Average number of hunt days & Dexter (2010); data summations by Minn. Department of Natural Resources biometrician
\end{tabular}

Percent on private vs. public land $\quad$ Bangsund and Leistritz (2003)

Number of hunters in Minn. PPR $\quad$ Dexter (2010); data summations by Minn. Department of Natural Resources biometrician

Average number of hunt days Dexter (2010); data summations by Minn. Department of Natural Resources biometrician

Percent on private vs. public land Schroeder and others (2007)

\begin{tabular}{lll}
\hline & & \multicolumn{1}{c}{ Iowa } \\
\hline \multirow{3}{*}{ Number of hunters* in Iowa PPR } & Rifle & Iowa Department of Natural Resources (2010) \\
& Bow & Iowa Department of Natural Resources (2010) \\
& Muzz. & Iowa Department of Natural Resources (2010) \\
\multirow{3}{*}{ Average number of hunt days } & Rifle & North Dakota State Game and Fish Department (2011b) \\
& Bow & North Dakota State Game and Fish Department (2011b) \\
& Muzz. & North Dakota State Game and Fish Department (2011b) \\
Percent on private vs. public land & Rifle & Bangsund and Leistritz (2003) \\
& Bow & Bangsund and Leistritz (2003) \\
& Muzz. & Bangsund and Leistritz (2003) \\
\hline
\end{tabular}
Pheasants

Iowa Department of Natural Resources (2010); total resident and nonresident pheasant hunter figures were matched up with survey results from the 2009-2010 Small Game Harvest Report (Bogenschutz

Number of hunters in Iowa PPR and Roberts, 2010) that indicated the percentage of hunters who hunted pheasants primarily in the northwest, northcentral, and central zones (largely representative of the Prairie Pothole Region section of the state)

Average number of hunt days Bogenshutz and Roberts (2010); authors provided separated average day estimates for resident and nonresident pheasant hunters

Bogenshutz and Roberts (2010); provided for resident and nonresident; percentage of respondents who

Percent on private vs. public land indicated hunting both private and public lands where split and distributed evenly to public and private totals Waterfowl

Iowa Department of Natural Resources (2010); resident and nonresident percentages were provided by waterfowl research specialist, Guy Zenner, who reviewed the percentages over the past five years

Number of hunters in Iowa PPR (2010 estimates were not available); these figures were then applied to the percentage of duck and goose (separately) hunters who indicated the hunted primarily in Region 1 (northwestern Iowa) in a 2006 Waterfowl Hunter Survey (provided by Guy Zenner)

Average number of hunt days see row directly above

Percent on private vs. public land Gary Zenner, Iowa Department of Natural Resources, written commun. in reference to 2006 Iowa Waterfowl Hunter Survey data, 2012

*Harvest figures were matched with success rates provided in the report to estimate the total number of hunters in the Prairie Pothole Region of the state. 
Table C-2. Hunting data for the Prairie Pothole Region of the United States by target, method, land access, and distribution of costs.

[*, State-level spending profiles were refined to the regional level by consulting with state wildlife agency representatives familiar with hunting activity and spending patterns. After consultation, spending amounts were not altered in PPR counties in North Dakota, South Dakota, and Iowa. Minnesota estimates were refined given the presence of the Twin Cities and likelihood some spending took place outside of the PPR boundary in those metropolitan areas. The Minnesota estimates were refined in a couple of ways. First, a database of Minnesota deer hunting licenses was acquired from the Minnesota Department of Natural Resources, which contained hunter's county of residence and the hunting unit/area in which they indicated they hunted the most. From more than 426,000 license entries, we calculated the proportion of hunters and PPR residents. Of the hunters hunting in the PPR, it was determined 69 percent also live in the region. The remaining 31 percent of hunters were treated as nonresidents in the modeling exercise. These proportions also were applied to pheasant and waterfowl estimates, given the limitations in the data. Based on further consultation with area experts, it was assumed 45 percent of state-wide expenditures on deer hunting (by resident and nonresidents) occurred within the area. We assumed 65 percent of total expenditures for pheasant and waterfowl hunting took place within the PPR boundary of Minnesota. Abbreviation: muzzle, muzzle-loading rifle; NA, data not available; PPR, Prairie Pothole Region, \$, United States dollars]

\begin{tabular}{|c|c|c|c|c|c|c|c|c|c|c|}
\hline \multirow{2}{*}{$\begin{array}{c}\text { PPR region total } \\
\text { License type }\end{array}$} & \multirow[b]{2}{*}{$\begin{array}{c}\text { Total \# } \\
\text { of hunters } \\
\text { in PPR (2010) }\end{array}$} & \multirow[b]{2}{*}{$\begin{array}{c}\text { Private } \\
\text { only days }\end{array}$} & \multirow[b]{2}{*}{$\begin{array}{l}\text { Public } \\
\text { only days }\end{array}$} & \multirow[b]{2}{*}{ Total days } & \multicolumn{6}{|c|}{ Daily expenditures (inflation-adjusted to 2011 \$) } \\
\hline & & & & & $\begin{array}{c}\text { Daily } \\
\text { variable } \\
\text { costs (\$) } \\
\end{array}$ & $\begin{array}{c}\text { Daily } \\
\text { fixed } \\
\text { costs (\$) }\end{array}$ & $\begin{array}{c}\text { Daily } \\
\text { total (\$) }\end{array}$ & $\begin{array}{l}\text { Percent } \\
\text { expended } \\
\text { in PPR* }\end{array}$ & $\begin{array}{c}\text { PPR } \\
\text { variable } \\
\text { cost } \\
\end{array}$ & $\begin{array}{c}\text { PPR } \\
\text { fixed } \\
\text { costs } \\
\end{array}$ \\
\hline Resident Rifle & 257,544 & 893,183 & 316,261 & $1,015,544$ & 91.60 & 97.29 & 188.89 & 76 & 69.62 & 73.94 \\
\hline Nonresident Rifle & 10,124 & 35,559 & 11,739 & 241,198 & 186.92 & 41.20 & 228.12 & 51 & 95.33 & 21.01 \\
\hline Resident Muzz. & 27,235 & 145,663 & 60,679 & 159,210 & 91.60 & 97.29 & 188.89 & 63 & 57.71 & 61.29 \\
\hline Nonresident Archery & 4,442 & 45,879 & 11,794 & 171,380 & 212.19 & 30.22 & 242.41 & 61 & 129.44 & 18.43 \\
\hline \multicolumn{11}{|c|}{ Pheasants } \\
\hline Resident & NA & 913,315 & 302,653 & $1,084,687$ & 62.46 & 80.04 & 142.50 & 90 & 56.21 & 72.04 \\
\hline Nonresident & NA & 389,675 & 109,759 & 630,716 & 167.30 & 29.76 & 197.06 & 92 & 153.92 & 27.38 \\
\hline \multicolumn{11}{|c|}{ Waterfowl } \\
\hline Resident & NA & 673,443 & 245,044 & 760,107 & 71.47 & 106 & 178.05 & 83 & 59.32 & 88.46 \\
\hline
\end{tabular}

Publishing support provided by:

Denver Publishing Service Center, Denver, Colorado

For more information concerning this publication, contact:

Center Director, USGS Fort Collins Science Center

2150 Centre Ave., Bldg. C

Fort Collins, CO 80526-8118

(970) 226-9398

Or visit the Fort Collins Science Center Web site at:

http://www.fort.usgs.gov/

This publication is available online at:

http://pubs.usgs.gov/pp/1800/ 
